\begin{abstract}
UNIVERSIDADE DE BRASÍLIA - UNB
INSTITUTO DE CIÊNCIAS SOCIAIS - ICS

DEPARTAMENTO DE ESTUDOS LATINOAMERICANOS - ELA

PROGRAMA DE PÓS-GRADUAÇÃO EM ESTUDOS COMPARADOS SOBRE AS AMÉRICAS
\end{abstract}

\title{
DEMOCRATIZAÇÃO SUBNACIONAL E DECISÕES SOBRE OS ASSUNTOS PÚBLICOS. Análise comparada do OP em Porto \\ Alegre, Brasil e da AMPP em Cárdenas, Cuba
}

HANS CARRILLO GUACH 
HANS CARRILLO GUACH

\section{DEMOCRATIZAÇÃO SUBNACIONAL E DECISÕES SOBRE OS ASSUNTOS PÚBLICOS. Análise comparada do OP em Porto Alegre, Brasil e da AMPP em Cárdenas, Cuba}

Tese de Doutorado apresentada ao Programa de PósGraduação em Estudos Comparados sobre as Américas, do Centro de Pesquisa e Pós-Graduação sobre as Américas (CEPPAC) da Universidade de Brasília, como requisito parcial para a obtenção do Título de Doutor em Ciências Sociais com ênfase em Estudos Comparados sobre as Américas, sob a orientação do Prof. Dr. Camilo Negri. 


\title{
Banca Examinadora
}

\author{
Prof. Dr. CAMILO NEGRI
}

Prof. Dr. MOISÉS VILLAMIL BALESTRO

Prof. Dra. REBECCA FORATTINI ALTINO MACHADO LEMOS IGREJA

Prof. Dra. MARCIA GUEDES VIEIRA

Prof. Dra. ANDREA FREIRE DE LUCENA

Prof. Dr. MARTIN-LÉON-JACQUES IBÁÑEZ DE NOVION (suplente) 


\section{RESUMO}

A presente pesquisa tem como objetivo comparar o Orçamento Participativo (OP) de Porto Alegre (RS), Brasil e a Assembleia Municipal do Poder Popular (AMPP) em Cárdenas, Cuba, nas questões referentes às suas contribuições para democratizar as decisões sobre os assuntos públicos, analisando como as citadas ferramentas facilitam a incidência da população em três áreas fundamentais associadas aos processos de democratização. Essas áreas são: as condições que sustentam a tomada de decisões no nível municipal, o controle sobre os atores políticos, assim como o controle das decisões relativas a esses assuntos. Em termos metodológicos, a pesquisa se desenvolveu a partir de uma metodologia qualitativa, sustentada numa comparação sincrônica orientada por casos diferentes. Os principais métodos empíricos utilizados foram: entrevistas semiestruturadas (para cidadãos $\mathrm{e}$ especialistas nas temáticas tratadas em ambos os países) e análise de documentos. Como principais resultados obtidos, demonstra-se a maneira como o OP e AMPP apresentam certas semelhanças que permitem identificar algumas das suas limitações como experiências de democratização das decisões, apesar das suas deferências.

\section{PALAVRAS CHAVES:}

Desenvolvimento democrático; regimes políticos; participação; cultura política. 


\begin{abstract}
This research aimed to compare the Participatory Budgeting (OP) in Porto Alegre, Brazil and the Municipal Assembly of People's Power (AMPP) in Cárdenas, Cuba on issues relating to their contributions to democratize the decisions over public matters, analyzing how the mentioned tools facilitate the incidence of the population in three keys areas associated to the democratization process. The areas are: the conditions that sustain the decision-making process in a municipal level, the control over political actors and the control over the decisions related to the subjects previously mentioned. As for the methodology, the research was developed over a qualitative approach, sustained over a synchronic comparison guided by different cases. The main empirical methods used were: semi-structured interviews (for citizens and specialists in the themes dealt in question on both countries) and document analysis. The results obtained demonstrate that the OP and AMPP present certain similarities that allow identifying their limitations as democratization experience, among their differences.
\end{abstract}

\title{
KEYS WORDS:
}

Democratic development; political regime; participation; political culture 


\section{DEDICATÓRIA}

Para meus pais (Rita, Enrique, Mavel) e minha família em geral, todos meus esforços. 


\section{AGRADECIMENTOS}

Agradeço profundamente às minhas duas mães (tia Rita e Mavel) e a meu pai (Enrique), por toda a força, o carinho e o apoio, especialmente pelas orientações que sutilmente impulsionaram em mim estes rumos acadêmicos que hoje me satisfazem. Reconheço os sacrifícios e as preocupações que para vocês têm implicado minha formação. Um especial agradecimento para minha amiga e companheira da vida durante os últimos 6 anos, Angélica, por sua compreensão, seu apoio e seu amor. Sua presença tem sido fundamental neste processo. Agradeço também a meus padrinhos, pela amizade e a preocupação por meu bem-estar.

A todos (as) os (as) educadores (as) da minha vida, particularmente os (as) professores (as) do Departamento de Sociologia da Universidade da Havana, por seus ensinamentos e pelas preocupações intelectuais que fizeram despertar em mim. Agradeço especialmente a Roberto Dávalos, Ángela Isabel e Teresa Muñoz por, além de seus papéis como professores (as), terem facilitado a construção de uma significativa amizade. Eu sozinho não poderia ter chegado até aqui. A todos (as) os (as) professores (as) do CEPPAC que me ensinaram por estes 4 anos e pela forma em que me acolheram, especialmente Camilo, que desde minha chegada ao Brasil estendeu suas mãos para mim e além de orientador tem sido mais um amigo nesta difícil separação física familiar. A Jacques, Moisés e Rebecca, pelas conversas e pelo apoio. Ao pessoal que tem passado pela secretaria do CEPPAC (Lucas, Jacinta) e também aos que hoje estão (Cecília, Paloma, Mariana, Socorro, Pablo), pelo afeto mostrado que contribuíram igualmente para uma estada mais amena no Brasil.

Aos amigos que no transcorrer destes anos compartilharam comigo momentos tanto difíceis quanto gratos e que suportaram e entenderam minha "cubanidade". Deles sempre tive o apoio toda vez que precisei: Vogly, Jehyra, José Manuel, Luduvico, Rogerio, Carolina Alzate, David, Ana, Elizabeth Ruano, Marcia Guedes. A todos meus colegas da Universidade de Matanzas, Cuba e do CEPPAC (de forma especial: Nei, Marcelle, Adalberto, Osvaldo), que de alguma forma ou outra me ajudaram neste processo de formação. Aos colegas da Colina (bloco K), pela afetuosa interação cotidiana que contribuiu para minha paz e meu entendimento sobre o Brasil e sua diversidade: Cristiano, Adriano, Christe Hélida (Chris), Rodrigo, Diego, Edivão, Antonio. Um agradecimento também para meus colegas cubanos em Brasília, que me ajudaram a combater a saudade da minha cultura: Javier, Leosbel, Janny, Yadian, Nelson, Osmel (desculpem os outros).

Aos atores em Porto Alegre e Cárdenas que contribuíram com a minha pesquisa. Particularmente, gostaria de agradecer pela forma em que fui recebido em cada espaço que visitei em Porto Alegre (prefeitura, CARs, casas de Delegados, Conselheiros e habitantes, UFGRS, PUCRS) e pela dedicação e pelo carinho das pessoas entrevistadas. Também aos amigos que gentilmente me hospedaram compartilhando comigo seus espaços: Muriel, Pablo e Lia. Em Cárdenas, agradeço aos Delegados, Presidentes dos Conselhos Populares, habitantes e especialistas. Sem a ajuda, as experiências e os conhecimentos de vocês não teria sido possível esta pesquisa. E por fim agradeço às instituições financiadoras, porque os recursos econômicos foram imprescindíveis neste processo de formação: UnB (auxílio para congresso/pesquisa, alimentação, moradia); CAPES PEG-PG (bolsa doutorado). 


\section{ABREVIATURAS OU SIGLAS}

- $\mathrm{AMPP}=$ Assembleia Municipal do Poder Popular

- $\mathrm{ANPP}=$ Assembleia Nacional do Poder Popular.

- $\mathrm{CAM}=$ Conselho de Administração Municipal.

- CARs $=$ Centros Administrativos Regionais

- $\mathrm{CGT}=$ Comitês Gestores do Território

- $\mathrm{COP}=$ Conselho do Orçamento Participativo.

- $\mathrm{CP}=$ Conselhos populares

- Dc. $=$ Delegados de circunscrição

- DEMAE = Departamento Municipal de Água e Esgoto

- FROP = Fórum Regional do Orçamento Participativo.

- $\mathrm{GSL}=$ Governança Solidária Local.

- OMPP = Órgãos Municipais do Poder Popular.

- $\mathrm{OP}=$ Orçamento Participativo.

- $\mathrm{PA}=$ Porto Alegre

- Pcp. $=$ Presidentes de Conselhos Populares

- $\mathrm{PI}=$ Plano de Investimento.

- $\mathrm{PMPO}=$ Prefeitura Municipal De Porto Alegre

- $\mathrm{PR}=$ Plenárias Regionais .

- Rc. = Rendições de contas

- $\mathrm{RI}=$ Regimento Interno.

- SeAMPP $=$ Sessões da Assembleia Municipal do Poder Popular. 


\section{SUMARIO}

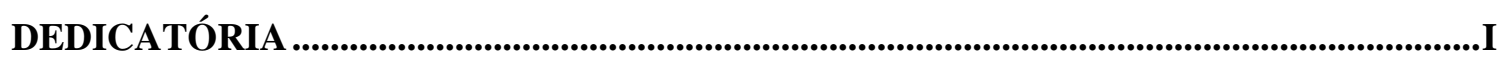

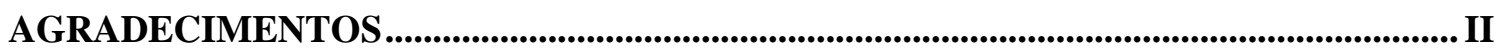

ABREVIATURAS OU SIGLAS ...............................................................................................

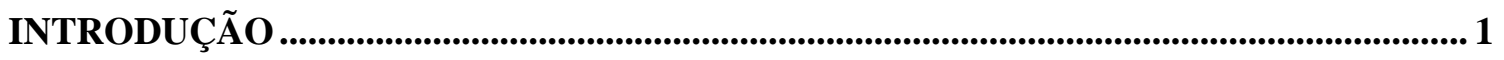

1. OP EM PORTO ALEGRE E A AMPP EM CÁRDENAS. CONSTRUINDO O OBJETO

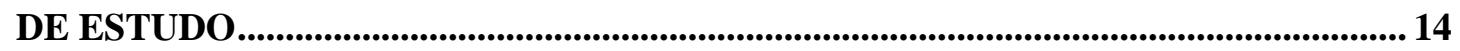

2. DEMOCRACIA E DEMOCRATIZAÇÃO ........................................................ 24

2.1 Abordagens sobre a democracia: Joseph Schumpeter e Robert Dahl ................................... 26

2.2 A democracia participativa na visão de macpherson e habermas .......................................... 33

2.3 A democratização: fundamentos para uma abordagem dinâmica sobre o objeto de estudo. 41

3. OP E AMPP EM PERSPECTIVA COMPARADA: CAPACIDADES PARA INFLUIR NAS CONDIÇÕES DA TOMADA DE DECISÕES.......................................................58

3.1 Estabelecimento de procedimentos para favorecer o debate público e a tomada de

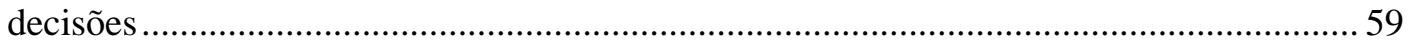

3.2 As normativas que sustentam os processos decisórios sobre os assuntos públicos. …….... 68

3.3 A agenda dos debates públicos, seus modos de definição e supervisão. ………………...... 77

4. OP E A AMPP EM PERSPECTIVA COMPARADA: CONTROLE DOS ATORES

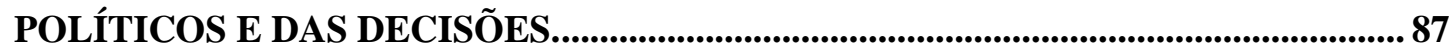

4.1 Socialização de informações e avaliação da gestão governamental em função dos assuntos

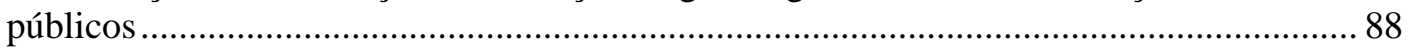

4.2 Capacidades de sanção sobre os atores políticos ............................................................... 97

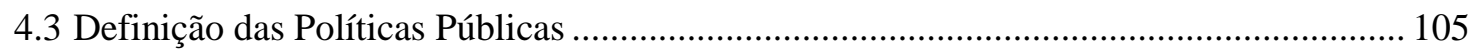

4.4 Contribuições para informar e debater (refutar e aceitar decisões) decisões a serem

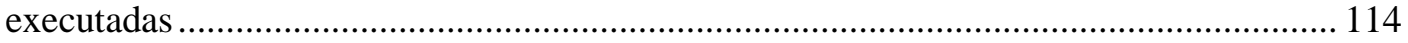

4.5 Papel na supervisão da execução das decisões tomadas no território.................................. 122

5. OP E A AMPP. REFLEXÕES COMPARATIVAS SOBRE CAPACIDADES DE DEMOCRATIZAÇÃ̃O............................................................................................................... 131

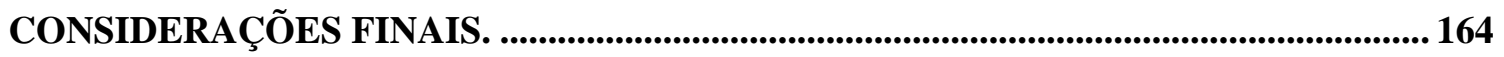

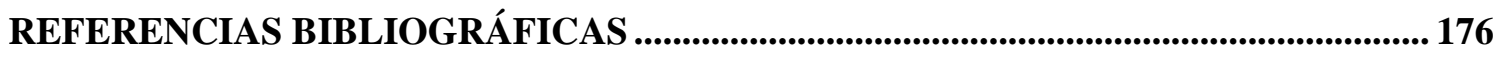

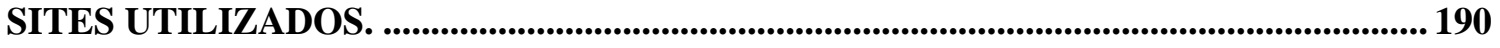

ANEXO 1. GUIA DE ENTREVISTA ATORES EM CÁRDENAS, CUBA E PORTO ALEGRE, BRASIL............................................................................................................. 191

ANEXO 2. GUIA DE ENTREVISTA PARA ESPECIALISTAS ...................................... 193 


\section{INTRODUÇÃO}

A abertura à diversificação de fontes de empoderamento da cidadania diante dos assuntos públicos é uma das consequências da democratização, que se configura como tendência nas muitas democracias modernas (DAHL, 2005), especialmente nas recentes democracias da América Latina. Essa abertura tem facilitado a ampliação do campo da política e um avanço na construção da cidadania na região.

A proliferação de experimentos que buscam aprofundar e inovar as democracias representativas, apesar de muitos resultados positivos, esbarra nas limitações próprias do funcionamento e da cultura política relacionadas com o modelo representativo. Desta forma, dificilmente as experiências conseguem contornar a insatisfação social em relação à justiça social, à eficácia da gestão governamental, à participação cidadã nas decisões sobre os assuntos públicos, ao controle dos atores políticos, à inclusão política, dentre outras temáticas (DAGNINO, et al., 2006; PRZEWORSKI, 2010; LATINOBARÓMETRO, 2015).

A realidade democrática, constituída por acertos e desacertos, consertos e desconsertos e delimitada por fatores materiais e subjetivos é, atualmente, um dos objetos mais recorrentes nas agendas de pesquisas sobre América Latina. Nesse sentido, estudos sobre autoritarismos e transições democráticas, dinâmicas da sociedade civil, consolidação democrática, qualidade das democracias, governabilidade, cidadania e democratização, figuram dentre os principais a indicar uma orientação das preocupações sobre o processo na região (O'DONNELL e SCHMITTER 1991; MAINWARING \& SHUGART, 1997; ROSENMANN, 2001; HOPENHAYN, 2001; MORLINO, 2004, 2009; GRAMMONT, 2006; DAGNINO, et al., 2006; MUNCK, 2007; LEVINE E MOLINA, 2007; ANSALDI, 2007; PUIG, 2009; LISSIDINI, 2011; CHERESKY, 2012; ACOSTA, 2014; LISSIDINI, et al., 2014, LUCCA e PINILLOS, 2015; BAZZI, 2015; GEARY et al., 2015; XAVIER e 
AVILA, 2016; CASANOVA, 2016; FILMUS, 2016; ACOSTA, GIORDANO e SOLER, 2016).

Apesar da diversidade de pesquisas sobre as democracias latino-americanas, e de sua recorrente crítica à representação política, ainda persiste uma ausência de investigações sobre contextos subnacionais. Neste nível da organização social existem vantagens para o desenvolvimento de processos importantes vinculados à democratização. Entre esses processos se destacam o favorecimento da legitimidade das decisões, assim como a sinergia entre governos e sociedade civil que beneficiem, por uma parte, a flexibilidade, adaptabilidade e as capacidades de gestão territorial diante dos assuntos públicos; por outra, que favoreçam transformações sociais consonantes com os interesses e as necessidades dos cidadãos.

Dito isso, uma dessas insuficiências está relacionada com a subrepresentação de estudos sobre os mecanismos ou as experiências a partir das quais se sustentam os atuais processos democráticos no nível mencionado (BEHREND, 2012). As análises sobre as dinâmicas desses mecanismos e suas resultantes em matéria de democratização das decisões sobre os assuntos públicos têm sido, até agora, pouco desenvolvidas, a despeito da sua importância para o desenvolvimento eficiente da democratização.

Fazendo um breve parêntese, no que se refere a esse tipo de análises nos locais onde esta pesquisa se desenvolveu, observa-se que em Porto Alegre (Brasil) as pesquisas têm sido mais recorrentes do que em Cárdenas (Cuba). No primeiro caso, destacam-se autores como ABERS (2000), BAIERLE (2000, 2009, 2012), RUBIN and BAIERLE (2014), AVRITZER (2002a, 2002b, 2014), LUCHMANN (2002), CABANNES (2004), GONZÁLEZ (2007), SANTOS e AVRITZER (2002) e MARQUETTI (2002), entre outros, que revelam importantes informações sobre o OP e sua relação com temas como sociedade civil, movimentos sociais, democracia local, desenhos institucionais e aprofundamento da democracia. Em Cárdenas, por outro lado, não se têm registrado pesquisas no âmbito aqui examinado, exceto as do próprio autor do presente trabalho (GUACH, 2016; GUACH e NEGRI, 2016). 
No entanto, em outros territórios cubanos têm sido realizadas pesquisas associadas a questões estruturais e subjetivas, relativas a temas como participação, democracia, sistema político (RÍOS, 1996; DILLA, 1996, 2000, 2007; PALMIRA, 2000; FLEITES et., al., 2004; PAZ, 2009; SUÁREZ, 2011; CHAGUACEDA, 2008, 2012; GUANCHE, 2011, 2012; CHAGUACEDA e GEOFFRAY, 2013). Essas pesquisas contribuem para entender de certa forma os processos de democratização em Cárdenas, devido à universalidade das formas de organização dos territórios em Cuba. As reflexões que nesses trabalhos e outros (WHITEHEAD, 2016) se podem encontrar abarcam posições diversas, transitando entre enfoques que assumem o sistema político cubano como autoritarismo e outros que se mantém reconhecendo suas limitações e potencialidades enquanto sistema democrático em construção.

Voltando às questões dos mecanismos que sustentam os processos democráticos subnacionais, e que neste trabalho também são entendidos como experiências, para autores como LISSIDINI, et al (2014) os mesmos ${ }^{1}$ instituem os pilares que, diante dos processos decisórios, fundamentam as interelações entre o Estado e a sociedade civil. Desse modo, eles resultam em meios para o exercício de cidadania, materializando oportunidades e capacidades para incidir na construção da realidade social nas suas diversas dimensões.

Outra insuficiência se encontra nos países abordados nas pesquisas mais visíveis. As comparações entre países como Cuba e Brasil não tem sido habituais, apesar das particularidades políticas (combinação de elementos democráticos e autoritários). A comparação se torna interessante enquanto Cuba, marcada por um sistema de Partido Único, e Brasil, caracterizado por um sistema pluripartidário, condicionam dinâmicas políticas e decisórias particulares.

\footnotetext{
${ }^{1}$ Esses mecanismos são chamados por LISSIDINI, et al. (2014) de mecanismos de democracia direta. Sem embargo, para os efeitos do atual trabalho, tanto o OP quanto a AMPP são concebidas principalmente como experiências democráticas que envolvem vários mecanismos e procedimentos, mais do que mecanismos em si mesmo. Isso está condicionado pelo reconhecimento da AMPP em Cuba como uma forma de organização política do município, enquanto que o OP tem sido reconhecido tanto como um mecanismo quanto uma experiência. Diante dessa divergência, assumir o OP e a AMPP como experiências permite uma concepção mais adequada para a comparação, como ponto médio e/comum capaz de revelar mais nitidamente suas semelhanças em contextos diferentes.
} 
Ao mesmo tempo, apesar do interesse histórico sobre suas idiossincrasias, o sistema político cubano costuma ser desconsiderado, tanto nas análises sobre as democracias atuais quanto nas reflexões sobre a teoria da Democracia (apesar das diferentes experiências participativas e conquistas sociais e além das suas limitações democráticas). O Brasil, por sua vez, ocupou um lugar de reconhecimento internacional nos últimos anos, a despeito das realidades contraditórias que assinalam processos restringidos de incidência direta da população na configuração política e social do país. Exemplos dessa realidade são os jogos políticos que conduziram o impeachment de Dilma Rousseff (eleita por maioria de votos nas eleições do ano 2014), bem como o conjunto de problemáticas sociais que para vários autores são importantes e devem ser atendidas em qualquer sistema democrático: desigualdade, pobreza, insegurança, analfabetismo, acesso a serviços públicos fundamentais, assim como a dependência econômica dos processos eleitorais, entre outros.

Considerando os argumentos anteriores, estabelece-se a pertinência de comparações entre esses dois países (suas semelhanças e diferenças), como possíveis fundamentos de um diálogo crítico com as teorizações sobre a democracia. Especificamente, tal pertinência se reafirma quando essas análises se localizam num contexto latino-americano, brasileiro e cubano em particular, onde não se têm potencializado suficientes estudos comparativos sobre mecanismos e processos democráticos no nível local. Assim, tais estudos se configuram como estratégia viável para estabelecer uma base gnosiológica que também permita dialogar criticamente com as realidades democráticas construídas socialmente e com os discursos hegemônicos sobre a democracia, centrados em perspectivas procedimentais liberais ${ }^{2}$.

2 Refere-se principalmente ao princípio de alternância do poder como um dos elementos centrais dessa perspectiva. A ausência dessa alternância em Cuba sustenta certas noções sobre esse país como regime autoritário e/ou ditadura. Não obstante, o autor do presente trabalho considera que diversos fatores, além da alternância de poder, deveriam ser considerados, pois outras experiências democráticas na América Latina baseadas nessa alternância (Brasil, Colômbia, México, Estados Unidos), não tem demonstrado um nível satisfatório da cidadania em relação à sua incidência na configuração política e social dos seus países (PRZEWORSKI, 2010; LATINOBARÓMETRO, 2015). 
Frente à escassez de pesquisas comparadas sobre mecanismos e experiências democráticas em contextos tão díspares como o cubano e o brasileiro, e tendo em vista a relevância desses mecanismos para a dinâmica local de empoderamento da cidadania e de construção e consolidação democrática, a presente tese procura contribuir comparando as experiências do Orçamento Participativo (OP) ${ }^{3}$ em Porto Alegre, Brasil e da Assembleia Municipal do Poder Popular (AMPP) ${ }^{4}$ em Cárdenas, Cuba. Particularmente, a comparação enfatiza o funcionamento da estrutura democrática que comumente envolve o OP e a AMPP: posições de atores e suas funções, mecanismos, dinâmicas de alguns atores nos processos de democratização de certas decisões. A ênfase mencionada viabiliza a comparação entre o OP e a AMPP apesar das suas naturezas socialmente reconhecidas (instrumento e/ou processo participativo versus estrutura organizativa local) e também explica porque algumas questões associadas, por exemplo, à AMPP, não sejam consideradas como objeto de reflexão: dimensão legislativa, estrutura geral da AMPP, entre outros.

Atendendo às informações oferecidas até aqui, que revelam a importância de ampliar o conhecimento sobre experiências democráticas sub-representadas nas análises comparativas na América Latina, o presente trabalho aborda como tema de pesquisa as contribuições do OP de Porto Alegre e da AMPP de Cárdenas à democratização das decisões sobre assuntos públicos. Consequentemente, para desenvolver as análises pertinentes em função do tema delimitado, se assume o

${ }^{3}$ O OP é um instrumento democrático e de participação popular na configuração dos assuntos públicos, estimulando o exercício da cidadania e a corresponsabilização entre governo e sociedade sobre a gestão da cidade. É um processo pelo qual a população, além de decidir de forma direta a aplicação dos recursos em obras e serviços que serão executados pela administração municipal, também discute e influi sobre as decisões relativas a outros assuntos que transcende a questão orçamentária (PMPA, 2015 / http://www2.portoalegre.rs.gov.br/op/default.php?p_secao=15).

${ }^{4}$ As AMPP são os máximos órgãos superiores locais do poder do Estado em cada localidade. Estão integradas pelos diferentes diretivos municipais (Saúde, Educação, Cultura, empresas estatais, entre outros) assim como por representantes da população. Entre esses Delegados de circunscrição. A própria Constituição da República de Cuba as define como "constituidas en las demarcaciones político-administrativas en que se divide el territorio nacional, son los órganos superiores locales del poder del Estado, (...). Para el ejercicio de sus funciones, las Asambleas Locales del Poder Popular se apoyan en los Consejos Populares y en la iniciativa y amplia participación de la población y actúan en estrecha coordinación con las organizaciones de masas y sociales (...). Dentro de los límites de su competencia, las AMPP tienen determinadas atribuciones; entre estas destaca: ...ejercer la fiscalización y el control de las entidades de subordinación municipal, apoyándose en sus comisiones de trabajo" (ANPP, 2010, p. 105-106). Para desenvolver suas funções com uma perspectiva de participação, a AMPP consta também com uma estrutura e diferentes instrumentos participativos, que constituem as principais unidades de análise do presente estudo. 
seguinte problema de pesquisa: como o atual funcionamento (2015-2016) desses mecanismos contribui para a democratização das decisões sobre os assuntos públicos nos seus respectivos municípios?

Assim sendo, ainda resulta necessário destacar outros componentes metodológicos que sustentam a atual pesquisa. Trata-se das hipóteses e do conjunto de objetivos delimitados, assim como dos métodos e das metodologias essencialmente utilizadas.

O presente trabalho parte do pressuposto de que tanto o OP em Porto Alegre quanto a AMPP em Cárdenas apresentam semelhanças no que tange às capacidades que oferecem para a democratização das decisões sobre os assuntos públicos, apesar das suas diferentes condições e trajetórias. Para rebater ou afirmar essa hipótese, na pesquisa mostrada a seguir se definiu como objetivo geral comparar o atual funcionamento do OP em Porto Alegre e da AMPP em Cárdenas, sobre a base das suas contribuições para a democratização das decisões sobre os assuntos públicos municipais. Em decorrência, de forma particular (objetivos específicos) se analisaram: 1) As similitudes e diferenças entre o OP em Porto Alegre e a AMPP em Cárdenas, no que se refere às capacidades que atualmente (2015-2016) facilitam a incidência dos cidadãos na configuração das condições de tomada de decisões municipais; 2) As semelhanças e diferenças nas capacidades que mediante o $O P$ em Porto Alegre e a AMPP em Cárdenas, adquirem atualmente os cidadãos para controlar tanto os atores políticos em função do tratamento dos assuntos públicos municipais, quanto às decisões relativas a esses assuntos públicos.

Com o propósito de esclarecer os diversos aspectos analisados em relação ao citado problema de pesquisa e de delimitar concretamente os modos de proceder desde o ponto de vista analítico, foi definido um conjunto de perguntas auxiliares de pesquisa. Essas perguntas, pelo fato de constituir uma ferramenta metodológica para orientar a obtenção de informações pertinentes para os fins aqui perseguidos, se agruparam segundo os objetivos específicos aos quais elas tributam. Nesse sentido, 
com o desígnio de assistir o primeiro objetivo específico ${ }^{5}$, se definiram as perguntas auxiliares a seguir, referidas ao OP em Porto Alegre e à AMPP em Cárdenas: 1Quais semelhanças e diferenças exibem em relação às suas contribuições para estabelecer procedimentos (alternativos ou não) que favoreçam os debates públicos e a tomada de decisões nos seus territórios? 2- Como se assemelham e diferenciam em relação às suas contribuições para debater (aceitar e refutar) o estabelecimento das normativas que regem a tomada de decisões municipais? 3- Quais semelhanças e diferenças têm em relação às capacidades que oferecem para que a população supervisione a definição da agenda dos debates públicos e influencie os modos de definir essa agenda nas suas localidades?

Continuamente, para orientar a procura de informações que permitam cumprir com a concepção do segundo objetivo ${ }^{6}$, se estabeleceram as seguintes perguntas: 4- Quais contribuições as instâncias oferecem para facilitar o acesso à informação sobre a gestão dos atores políticos (relacionadas com as demandas púbicas) e as suas justificativas? 5- Como se assemelham e diferenciam no referente às capacidades que oferecem para que a população avalie a gestão dos atores políticos frente às demandas públicas? 6- Quais similitudes e contrastes exibem enquanto às capacidades que oferecem para que a população exerça sanção sobre os atores políticos? 7- Como se assemelham e diferenciam o OP e a AMPP no referente às capacidades que oferecem para que a população incida na definição das políticas públicas e na supervisão da execução das decisões municipais tomadas? 8- Quais analogias e contrastes exibem os citados mecanismos quanto às suas contribuições para que a população seja informada e debata (refuta elou aceite) sobre as decisões relativas aos assuntos públicos, antes de elas serem executadas?

\footnotetext{
${ }^{5}$ Analisar as similitudes e diferenças entre o OP em Porto Alegre e a AMPP em Cárdenas, no referente às capacidades que facilitam para a incidência dos cidadãos na configuração das condições de tomada de decisões municipais.

${ }^{6}$ Analisar as similitudes e diferenças nas capacidades que, mediante o OP em Porto Alegre e a AMPP em Cárdenas, os cidadãos têm para controlar tanto os atores políticos em função do tratamento aos assuntos públicos municipais, quanto às decisões relativas a esses assuntos.
} 
Por outro lado, do ponto de vista essencialmente metodológico, a atual pesquisa se desenvolveu a partir de uma abordagem qualitativa, sustentada numa comparação sincrônica (MORLINO, 1994) orientada por casos. Seguindo a proposta de RAGIN (1987), a comparação enfatiza as variações existentes entre o OP e a AMPP, no que tange à maneira em que as duas experiências analisadas facilitam ou não a democratização das decisões sobre os assuntos públicos.

Particularmente, se realizou uma comparação orientada por casos diferentes, conforme a conhecida "comparação globalizante" proposta por BENDIX (1963). Essa tipologia de comparação consiste em analisar casos particulares dentro de contextos mais amplos e divergentes, como forma de facilitar a compreensão holística de determinados fenômenos sociais. Os casos particulares se referem ao OP e à AMPP como experiências concretas que, situadas em países com sistemas políticos diferentes e denominadas de democracia desde o discurso político oficial, perseguem objetivos mais ou menos similares: participação social.

A partir do desenvolvimento dessas experiências foram escolhidas as principais unidades de análise do presente estudo. Nesse sentido, a escolha esteve determinada pela centralidade das mesmas no processo que se pretender comparar: a democratização das decisões impulsionadas pelo OP e pela AMPP. Assim sendo, estas unidades são constituídas pelos atores e espaços que, nos marcos de ambas as experiências, as têm concebido para materializar o citado processo de democratização.

Desde o ponto de vista lógico, o método de indução analítica (RAGIN, 2007) foi utilizado para construir conhecimentos baseados na empiria que, permitindo desconstruir as realidades dos processos de democratização emergidas do funcionamento dos mecanismos já mencionados, facilitou o diálogo com a teoria. Por outro lado, o método dedutivo permitiu partir de enunciados teóricos gerais referentes à democratização para construir conhecimentos sobre a realidade analisada. 
Como métodos empíricos, se usaram as entrevistas semiestruturadas (aplicadas aos cidadãos e especialistas nas temáticas em ambos os países) e a análise de documentos ${ }^{7}$. A entrevista foi a principal ferramenta de acesso às informações pertinentes para a presente pesquisa, facilitando uma aproximação às experiências, às ideias, aos conhecimentos, às percepções, aos significados, às avaliações e aos sentimentos construídos pelos cidadãos, considerando a necessidade de distinguir as narrativas dos entrevistados segundo suas posições sociais: vínculos com a sociedade civil e/ou com o governo (BOURDIEU, 2002). O acesso a esse conjunto de elementos facilitou aprofundar nas possibilidades de ações que os procedimentos analisados oferecem para democratizar as decisões sobre os assuntos públicos.

Para o desenvolvimento do método anterior, a mostra de cidadãos entrevistados foi escolhida de forma não aleatória, considerando critérios como: disponibilidade para cooperar com a pesquisa, cargo ocupado no governo e cargo relacionado com o OP ou com a AMPP e anos de experiência no cargo (um ano ou mais). Nesse sentido, os sujeitos entrevistados em Porto Alegre foram: Viceprefeitos de Porto Alegre, Gestores dos CARs, Delegados, Conselheiros do OP e habitantes. Por outro lado, em Cárdenas, se entrevistaram: Delegados de circunscrição (Dc), Presidentes de Conselhos Populares (Pcp) e habitantes ${ }^{8}$.

Um dado interessante sobre a realização das entrevistas foi a maneira diferente em que transcorreram nos dois territórios. Em Porto Alegre, os entrevistados se mostraram mais ativos e motivados no fornecimento de informações sobre o OP, inclusive no estabelecimento de críticas. Tal atitude explica a maior quantidade de informações obtidas sobre essa experiência, em comparação com os dados que foram recolhidos em Cárdenas. Nesse caso, as posturas da maioria dos Dc e dos Pcp estiveram marcadas por uma maior mesura ao se estabelecer as limitações.

\footnotetext{
${ }^{7}$ Inicialmente também foram concebidas observações não participantes mas, por questões de tempo, não foi possível aplicá-las na sua totalidade. No entanto, em Porto Alegre, foram observadas algumas Sessões do COP, assim como reuniões do OP em algumas regiões: Cristal e CAR Norte. Em Cárdenas, essas observações foram realizadas em pesquisas anteriores (2011).

${ }^{8}$ Não foi possível entrevistar atores do governo.
} 
As explicações possíveis para esse fenômeno podem ser variadas. Um deles pode ser o papel da opinião pública na configuração da política no país, no contexto de um Estado centralizado, como estratégia de proteção do próprio sistema e da existência de um único partido político. Ambos os fatores, para o discurso político e para as bases socialistas que o sustenta, tem resultados viáveis (o qual não é objeto de discussão aqui), mas na prática tem limitado a cultura do debate critico sobre o próprio sistema, apesar do recorrente chamado que o atual presidente Raul Castro Ruz tem feito à sociedade para impulsionar atitudes críticas sobre a realidade cubana. A outra explicação possível é a imagem que o autor da presente obra poderia ter projetado para seus interlocutores, depois de ter pesquisado sobre temas similares no mesmo território.

Em relação aos especialistas, entrevistou-se um total de quatro, cuja seleção obedeceu aos seguintes critérios: disponibilidade para cooperar com a pesquisa e destacada trajetória (nesse caso acadêmica) relacionada com os processos estudados. No total, foram aplicadas 24 entrevistas. O propósito das mesmas foi contrastar as informações recolhidas, assim como validá-las, refutá-las e/ou aprofundá-las.

O outro instrumento utilizado, a análise de documentos, pode ser entendida brevemente como o conjunto de procedimentos orientados à análise e à interpretação da informação em determinados documentos e mensagens (OSIPOV, 1988). A presente pesquisa desenvolveu esse método através da interpretação e consulta reflexiva de documentos normativos referidos ao OP e à AMPP (resoluções constitucionais, manuais de procedimentos e documentos legislativos em geral), com o propósito de identificar a maneira em que neles se refletem as capacidades democratizadoras dos cidadãos diante dos assuntos públicos. Esse método, apesar de ter sido concebido inicialmente com igual centralidade na procura de informação (em comparação com a entrevista), por questões de tempo, foi aplicado principalmente para suprir informações que não foram dadas pelos entrevistados em Cárdenas. 
Por último, uma vez feita a coleta de informações e dados necessários, se conceberam vários procedimentos para realizar a etapa de análise dos resultados. Partindo da proposta de (GÓMEZ, et. al., 2002), se aplicou a chamada etapa de redução de dados. Nessa fase, foram estratificados os dados a partir de certos critérios temáticos relativos às dimensões de análise aqui concebidas (capacidade dos cidadãos para influenciar as condições da tomada de decisões, o controle dos atores políticos e as decisões). Posteriormente, esses dados foram categorizados a partir do modo indutivo 9 .

A seguir, realizou-se a fase de transformação de dados, onde se organizam as estruturas de dados e categorias, assim como as diferentes relações entre esses componentes. Nesse caso, foram estabelecidas as relações entre as declarações dos entrevistados, o objeto de estudo, a teoria utilizada e a posição social desses entrevistados. Finalmente se passou à etapa de obtenção de conclusões. Nela se reconstruiu um "todo" estruturado e significativo dos elementos diferenciados no processo analítico, apresentando os resultados e as interpretações dos mesmos para demonstrar as relações descobertas entre as categorias utilizadas no estudo ${ }^{10}$.

A tese foi organizada em cinco capítulos. O primeiro capítulo tem como objetivo identificar os principais elementos sociais que permitem construir o OP em Porto Alegre e a AMPP em Cárdenas como objetos de estudos de uma comparação orientada por casos diferentes. Com base nesse propósito, algumas informações referentes tanto às experiências examinadas, quanto os contextos políticos e sociais em geral onde eles se inserem são oferecidas neste capítulo.

Em relação às experiências, fornecem-se alguns dados históricos relacionados ao surgimento do OP em Porto Alegre e da AMPP em Cárdenas, assim como informações sobre suas estruturas (atores, funções, normativas, procedimentos, espaços). Ao longo do texto, destacam-se sempre suas semelhanças

\footnotetext{
${ }^{9}$ Essa categorização também pode ser feita utilizando categorias pré-definidas mediante o marco teóricoconceitual.

${ }^{10}$ Nesse processo, também foi concebida uma última etapa chamada de verificação de conclusões, onde se interagem com pesquisadores e com os participantes no estudo. Essa etapa, apesar de não ter sido executada, de alguma maneira foi cumprida, mediante as declarações dos especialistas entrevistados.
} 
em contextos divergentes, marcados pelas peculiaridades dos sistemas políticos e por características específicas relativas às questões geográficas e demográficas.

O segundo capítulo sistematiza algumas concepções sobre a Democracia e a Democratização, vistos como conceitos conexos, mas com implicações diferenciadas. Nesse sentido, os dois primeiros tópicos apresentam diferentes abordagens sobre a Democracia, a fim de examinar categorias que viabilizem uma ferramenta analítica teórica adequada para os propósitos que aqui se perseguem. Entre essas abordagens destacam-se as propostas de Joseph Schumpeter, Robert Dahl, Crawford B. Macpherson e Jürgen Habermas. A seguir, num terceiro tópico, analisam-se diferentes autores (Bobbio, O'Donnell, Whitehead, entre outros), destacando as vantagens de utilizar o conceito de Democratização para analisar os objetos de estudos antes definido. De igual modo, se revelam algumas implicações epistemológicas que derivam das teorizações expostas.

Os resultados da pesquisa são mostrados nos Capítulos 3,4 e 5 respectivamente. Nos dois primeiros (3 e 4) se exibem de forma comparada os conteúdos que permitem estabelecer as análises propostas sobre os papéis do OP e da AMPP na democratização das decisões sobre os assuntos públicos. Os dados que se oferecem estão sustentados nas duas dimensões analíticas que foram concebidas, conjuntamente com suas respectivas subdimensões (tópicos).

O Capítulo 3 discorre sobre o modo que o OP e a AMPP contribuem para que a população em Porto Alegre e Cárdenas influenciem nas condições que sustentam os processos decisórios. Associadas a essa dimensão, se analisam especificamente as seguintes subdimensões: 1) estabelecimento de procedimentos (alternativos ou não) que favoreçam o debate e tomada de decisões sobre os assuntos públicos, 2) estabelecimento de normativas que sustentam os processos de tomada de decisões nos municípios, 3) acompanhamento da definição da agenda dos debates públicos e 4) incidência nos modos de definir essa agenda. 
No Capítulo 4, desenvolve-se o exame das capacidades que o OP e a AMPP oferecem para que a população exerça controle sobre os atores políticos e, respectivamente, sobre as decisões tomadas nos seus territórios. Para analisar o papel dos mecanismos em questão no controle dos atores políticos, foram concebidas várias subdimensões, mostradas também em forma de tópicos. Estas são: 1) a socialização de informações e avaliação da gestão governamental em função dos assuntos públicos; 2) as capacidades de sansão sobre os atores políticos; 3) as capacidades de incidência dessas ferramentas na definição das políticas públicas; 4) a supervisão da execução das decisões e, por último, 5) os papeis do OP e da AMPP para facilitar que os cidadãos sejam informados e debatam sobre as decisões a serem adotadas e executadas.

Por fim, o Capítulo 5 contém uma síntese comparativa baseada nas duas dimensões analíticas concebidas e suas respectivas subdimensões. Essa síntese reflete as principais semelhanças e diferenças entre ambas as experiências, representando-as em quadros que facilitam uma melhor exposição dos conteúdos. Com base nas mencionadas sínteses e em seus diálogos com a teoria utilizada, estabelecem-se reflexões gnosiológicas e epistemológicas que, entre outros aspectos, abrem algumas possibilidades para futuras pesquisas.

Para finalizar essa seção introdutória, é preciso reafirmar que as informações mostradas a seguir não pretendem constituir argumentos conclusivos sobre os processos de democratização que derivam do funcionamento do OP e da AMPP. Especificamente, elas pretendem ser o inicio de uma produção de conhecimentos acumulativos ${ }^{11}$ sobre o processo e os casos em questão, que sirvam como referentes para entender os processos democráticos e retroalimentar as bases teóricas desse conceito, sobretudo a partir das variadas interrogantes e sugestões colocadas, algumas das quais necessitaram de posteriores exames mais profundos.

\footnotetext{
${ }^{11}$ Esses conhecimentos acumulativos são considerados como conhecimentos úteis segundo WHITEHEAD (2002).
} 


\title{
1. OP EM PORTO ALEGRE E A AMPP EM CÁRDENAS. CONSTRUINDO O OBJETO DE ESTUDO
}

\begin{abstract}
As cidades de Porto Alegre, no Brasil, e de Cárdenas, em Cuba, constituem duas realidades totalmente divergentes, considerando algumas das suas características, como extensão territorial, densidade populacional, sistemas políticos que as sustentam, etc.
\end{abstract}

Em relação às características demográficas, Cárdenas constitui um município localizado no norte da Província de Matanzas. Conta com uma extensão superficial aproximada de 555,66 $\mathrm{km}^{2}$ e com uma população residente de aproximadamente 147 419 habitantes. A densidade populacional é de 251,97 de habitantes $/ \mathrm{km}^{2}$, segundo a Oficina Nacional de Estadística (ONEI: 2015). Por outro lado, Porto Alegre tem uma população estimada de 1409351 e conta com uma área de unidade territorial de $496862 \mathrm{~km}^{2}$. No que tange à sua densidade populacional, essa cidade brasileira possui 2 837,53 de habitantes/km² (http://cod.ibge.gov.br/6L0).

Em relação aos sistemas políticos a partir dos quais se configura a realidade de ambos dois territórios, Cárdenas se insere num sistema político regido por um Estado socialista de trabalhadores, independente e soberano, organizado com todos e para o bem de todos, como república unitária e democrática. A concepção desse sistema político sustentaria, então, o desfrute da liberdade política, da justiça social, do bem-estar individual e coletivo, assim como da solidariedade humana, nos marcos de uma economia nacional dirigida e planificada centralmente pelo Estado cubano (ANPP, 2010).

Como república unitária e democrática, o órgão supremo do poder do Estado é a Assembleia Nacional do Poder Popular (ANPP), a qual representa e expressa a vontade soberana do povo. A ANPP é o único órgão com potestade constituinte e legislativa na República e se compõe de deputados eleitos pelo voto livre, direto e 
secreto dos eleitores, na proporção e segundo o procedimento que determina a lei (ANPP, 2010).

Por sua parte, Porto Alegre se insere numa República Federativa presidencialista, implicando que o Chefe de Estado é eletivo e temporário; que os Estados são dotados de autonomia política e que ambas as funções de Chefe de Governo e Chefe de Estado são exercidas pelo presidente. De igual modo, também se destaca, que o regime democrático brasileiro se fundamenta no princípio da soberania popular, segundo o qual todo poder emana do povo que o exerce por meio de representantes ou diretamente (CÂMARA DOS DEPUTADOS, 2012).

Apesar das breves diferenças mencionadas e da existência de outras que não são objeto de análise no presente trabalho, em ambos os contextos é possível identificar alguns elementos comuns. O primeiro elemento é a referência, desde o discurso oficial, à cidadania como principal detentora do poder político. O segundo são as experiências participativas e/ou democráticas no nível municipal, surgidas com o propósito aparente ou não de empoderar os cidadãos diante da configuração dos assuntos públicos e da política em geral, conforme o princípio citado.

Essas experiências, que no caso de Porto Alegre é o Orçamento Participativo e em Cárdenas é a Assembleia Municipal do Poder Popular, surgiram nesses territórios em contextos diferentes, mas com orientações relativamente similares. Além disso, é possível identificar em suas estruturas algumas características análogas.

O OP, implantado em 1989 na cidade de Porto Alegre, constitui uma das experiências democráticas mais significativas no Brasil, que inclusive tem ganhado destaque no nível internacional, sendo reconhecido pela ONU como uma das 40 melhores práticas de gestão pública urbana no mundo. Embora as diferentes noções existentes em relação às circunstâncias e aos interesses que condicionaram seu surgimento (BAIERLE, 2000; ABERS，2000; BAIOCCHI, 2005; AVRITZER, 2002a, 2014) pode-se mencionar que, de uma forma ou de outra, sua gênese e 
manutenção têm entre seus propósitos estreitar as relações entre governados e governantes perante a tomada de decisões no território.

Como procedimento democrático, não institucionalizado normativamente, ele se institui como um processo pelo qual a população decide de forma direta a aplicação dos recursos em obras e serviços que serão executados pela administração municipal. Com base nisso, o OP impulsiona o envolvimento dos cidadãos não eleitos na tomada de decisão sobre os assuntos públicos e seus orçamentos, contribuindo assim para a construção do bem comum através de debates entre o governo e a sociedade civil e, inclusive, entre os próprios atores da sociedade em questão. Essas relações se estabelecem a partir das atividades proporcionadas pelo OP constituem, portanto, uma forma de facilitar a transparência no funcionamento do governo, que tem suas implicações na redução de fenômenos como o clientelismo (FEDOZZI et. al., 2013; AVRITZER, 2014).

No caso da AMPP, suas lógicas apresentam pontos de contato com o OP, embora a questão orçamentária não esteja dentro das suas prioridades ${ }^{12}$. Essa forma organizativa do poder municipal surgiu em 1976, depois de um experimento piloto precisamente na cidade de Cárdenas. Sendo assim, as AMPP constituíram um avanço no aprimoramento dos procedimentos de gestão e administração pública, sobre a base de relações mais próximas entre o governo e a população. Essa situação implicou no desempenho de um papel mais relevante por parte dos municípios, que atuam como "filtros" em benefício da capacidade de resposta do Estado, ao transcender as tradicionais formas centralizadas, como o Conselho de Ministros e o Partido Comunista (DILLA, 1996) ${ }^{13}$.

Descritas rapidamente algumas características do OP em Porto Alegre e da AMPP em Cárdenas, assim como dos sistemas políticos onde eles se inserem, segue-

\footnotetext{
12 As similitudes se localizam, portanto, em outras arestas. É importante destacar que a centralidade histórica dos debates orçamentários no OP não deveria constituir um fator que incapacite a comparação entre as experiências, principalmente devido a que, nos últimos anos, o OP se constituiu um procedimento que transcende o debate simplesmente orçamentário.

${ }^{13}$ Isso não implica que hoje não exista tal centralização. Para mais informação sobre o tema, ver: DILLA, 2000, 2007; CAMPORREDONDO, 2006; ESPINA, 2006.
} 
se para o aprofundamento nas similitudes que justificam sua análise, como casos semelhantes em contexto diferentes. Considerando os anteriores argumentos, se percebem algumas analogias entre as duas ferramentas, que são necessárias esclarecer.

A primeira dessas analogias é que tanto Cárdenas quanto Porto Alegre são cidades de maior destaque nos seus respectivos países na execução de experiências relevantes de participação cidadã. A segunda analogia se aprecia nas orientações que sustentam a existência do OP e da AMPP.

A mais importante dessas orientações comuns é precisamente o objetivo de expandir as capacidades dos cidadãos para incidir na configuração das realidades social e política, em função das suas necessidades e seus interesses. Um exemplo concreto que demonstra as tentativas de ambos os mecanismos para empoderar a cidadania se visualiza nos documentos normativos que regulam o funcionamento de estruturas associadas a eles. Os fragmentos a seguir revelam o papel protagônico que a população adquire a partir do plano normativo nos processos de configuração das realidades locais orientados a satisfazer as suas necessidades:

"Las Administraciones Locales que estas Asambleas constituyen, dirigen las entidades económicas, de producción y de servicios de subordinación local, con el propósito de satisfacer las necesidades económicas, de salud y otras de carácter asistencial, educacionales, culturales, deportivas y recreativas de la colectividad del territorio a que se extiende la jurisdicción de cada una". "Para el ejercicio de sus funciones la Asamblea Municipal del Poder Popular se apoya en las comisiones de trabajo, en los Consejos Populares, en el Consejo de la Administración, así como en la iniciativa y amplia participación de la población, en estrecha coordinación con las organizaciones de masas y sociales". (ANPP, 1995, 2010) ${ }^{14}$.

"O Conselho do Orçamento Participativo é um órgão de participação direta da comunidade, tendo por finalidade planejar, propor, fiscalizar e deliberar sobre a receita e despesa do orçamento do Município de Porto Alegre, de acordo com o que preconiza (...). (...) trata-se de um processo dinâmico que se ajusta periodicamente às necessidades locais, buscando sempre um formato facilitador, ampliador e aprimorador do debate entre Governo e a população". (PMPA, 2015).

\footnotetext{
${ }^{14}$ Artigos 103 e 104 da Constituição da República de Cuba (ANPP, 2010) e Artigo 4 da ANPP (1995).
} 
Outra das orientações comuns entre os dois mecanismos deriva nos intentos por promover a necessária transparência no funcionamento do governo. $\mathrm{O}$ fato de que o OP e a AMPP estejam orientadas para estreitar as relações entre governados e governantes perante a tomada de decisões no território implica o estabelecimento de oportunidades para que a cidadania exerça controle sobre esses governantes. E essa ação se reverte simultaneamente em maiores possibilidades de transparência.

Um elemento que viabiliza essa transparência são os diferentes espaços de debates concebidos nos marcos das duas experiências. No âmbito do OP destacam o COP, os FROP e as PR. Em torno das AMPP, ressaltam as Rc e as SeAMPP, respectivamente. Nesses espaços, os atores governamentais e representantes populares eleitos têm o dever de participar, prestando contas da sua gestão.

No que se refere às funções estabelecidas para atores governamentais, como o presidente da AMPP, se encontra entre suas atribuições o atendimento aos Conselhos Populares e a análise em reuniões periódicas com os seus presidentes a marcha integral do seu trabalho (ANPP, 1995) ${ }^{15}$. Também, no transcurso dos debates (como os acontecidos nos marcos das Rc e das SeAMPP), os representantes populares têm direito de dirigir perguntas ao presidente, vice-presidente e/ou secretario da AMPP, sendo esses obrigados de responder na hora (no caso das SeAMPP), exceto quando precisem de um maior prazo que será acordado pela própria AMPP. De igual forma, os Dc (representantes do povo), devem prestar contas da sua gestão para seus eleitores, e conhecer periodicamente as informações sobre a gestão da AMPP, e a projeção de trabalho no território que coadjuvem para o cumprimento das suas funções.

"En el curso de los debates, los delegados tienen derecho a dirigir preguntas al presidente, vicepresidente y secretario de la Asamblea, a los integrantes de las comisiones de trabajo, a los miembros del Consejo de la Administración Municipal y a los directores administrativos de las entidades radicadas en el territorio. Estos están obligados a responder en la propia sesión, a menos que tengan

$\overline{{ }^{15} \text { Capítulo 5, inciso k (ANPP, 1995). }}$ 
necesidad de preparar la respuesta, caso en el cual lo hacen en el plazo que acuerde la Asamblea Municipal. (...) conocer periódicamente informaciones sobre la gestión de la Asamblea Municipal, de su Consejo de la Administración y la proyección de trabajo del territorio que coadyuven a su preparación para el cumplimiento de sus funciones". (ANPP, 1995) ${ }^{16}$.

Funções parecidas às anteriormente descritas, que configuram tentativas de transparência e de controle da gestão governamental, são observadas também no funcionamento do OP. O próprio ciclo de debates que se desenvolve nos marcos desse mecanismo, assim como o fato de que os secretários da prefeitura e demais atores governamentais devam participar desses debates e prestar contas sobre sua gestão, resultam em alguns dos indicadores do processo mencionado (PMPA, 2015):

"Ao Conselho do Orçamento Participativo compete: (...) Apreciar e
votar a Prestação de Contas do Governo, ao final de cada exercício,
baseado no relatório informatizado GOR (Plano de Governo e
Orçamento), com o detalhamento por demanda do que foi orçado, do
que foi empenhado e do que foi realmente executado. O Governo
deverá responder aos Conselheiros (as) das Regiões e Temáticas às
questões levantadas pelos mesmos no período de comunicações das
reuniões num prazo de 2 (duas) reuniões ordinárias, a contar da data
da solicitação. São Direitos dos Conselheiros (as): e) Solicitar
esclarecimentos e retorno sobre temas e demandas, investimentos,
serviços, ações do Governo que suscitem dúvidas de interesse de sua
Região ou Temática". (PMPA, 2015, p. 14, 17).

Um último elemento similar entre o OP e a AMPP dentro das suas diferenças mais globais é a sua estrutura, no que tange não só às funções de diferentes espaços como os já mencionados, como também aos atores que configuram ambas as experiências. Destaca-se a figura dos Delegados e Conselheiros como principais representantes populares e que funcionam como estratégia para empoderar a cidadania perante as decisões nos territórios. Em Cárdenas, esses sujeitos são chamados de Delegados de circunscrição ${ }^{17}$ e Presidentes de Conselhos Populares,

\footnotetext{
${ }^{16}$ Artigo 43.

${ }^{17}$ Os Delegados de circunscrição são reconhecidos pela lei como Delegados à Assembleia Municipal do Poder Popular.
} 
respectivamente. Em Porto Alegre, são denominados Delegados e Conselheiros do OP.

Os Dc cumprem uma função importante como representantes, sendo obrigados a manter vínculos diretos, permanentes e sistemáticos com seus eleitores a fim de atender e viabilizar suas problemáticas. Por conta disso, eles têm a obrigação de trabalhar constantemente para conhecer as situações que afetam a comunidade que representam, assim como suas causas, e encaminhar suas soluções. Para isso devem, inclusive, solicitar aos poderes responsáveis, quando necessário, a adoção de medidas pertinentes:

"Los delegados a la Asamblea Municipal del Poder Popular cumplen el mandato que les han conferido sus electores en interés de toda la comunidad. El delegado está obligado a mantener un vínculo real, permanente y sistemático con sus electores, atendiendo y viabilizando los asuntos planteados por éstos. Tiene la obligación de trabajar constantemente para conocer los problemas que afectan a sus electores y las causas que los generan; así como la de reclamar, cuando sea necesario, de quien corresponda la adopción de las medidas que se requieran para resolverlos, a fin de lograr una respuesta rápida y contribuir a elevar su autoridad ante los electores". (ANPP, 1995) ${ }^{18}$.

Ao mesmo tempo, esses Dc e Pcp não apresentam privilégios pessoais nem benefícios econômicos, o que os legitima como representantes genuínos da população (ANPP, 1995), assim como os Delegados e Conselheiros do OP. Além disso, os Dc mantém entre suas obrigações, agir como agente socializador de informações tanto para a AMPP quanto para a população, participar com voz e votos em diferentes espaços de debates (SeAMPP, reuniões das Comissões e dos CP), assim como fazer proposições sobre todas as questões diante das quais a AMPP tem faculdades para adotar acordos. Tais funções estão dispostas da seguinte forma:

“a) dar a conocer a la Asamblea y a la Administración de la localidad las opiniones, necesidades y dificultades que les trasmitan sus electores; b) informar a sus electores sobre la política que sigue la Asamblea y las medidas adoptadas para la solución de necesidades planteadas por la población o las dificultades que se presentan para

${ }^{18}$ Artigos 52 e 59. 
resolverlas; h) gestionar las soluciones y respuestas referentes a los planteamientos formulados por los electores; i) atender a los electores en despachos programados periódicamente; a) participar con voz y voto en las sesiones de la Asamblea Municipal y en las reuniones de las comisiones y Consejos Populares de que forman parte; c) hacer proposiciones sobre todas las cuestiones en las que la Asamblea Municipal está facultada para adoptar acuerdos". (ANPP, 1995) ${ }^{19}$.

Por sua vez, os (as) Pcp são constituídos (as) com finalidades que refletem tentativas de democratizar a gestão pública. Nesse sentido, esses atores devem trabalhar ativamente para satisfazer as necessidades assistenciais, econômicas, educacionais, culturais e sociais da população, na procura de soluções para suas problemáticas. Igualmente, têm o dever de promover a participação popular das instituições e entidades nas regiões lhes correspondem e desenvolver iniciativas que contribuam para o avanço das ações propostas para satisfazer a necessidades dos eleitores. Ante esse processo, os Pcp devem controlar e fiscalizar as atividades das entidades existentes nos seus territórios, assim como exigir eficiência no desenvolvimento das atividades de produção e serviços nas suas áreas de ação.

"El Consejo Popular, en el marco de su competencia, tiene entre otras las atribuciones y funciones siguientes: c) trabajar activamente para que se satisfagan las necesidades asistenciales, económicas, educacionales, culturales y sociales de la población y en la búsqueda de soluciones a los problemas planteados; g) promover la participación de la población, de las instituciones y entidades de la demarcación para desarrollar iniciativas que contribuyan a lograr el mayor avance en las tareas que se propongan, así como cohesionar el esfuerzo de todos; d) exigir eficiencia en el desarrollo de las actividades de producción y de servicios a las entidades enclavadas en su área de acción y apoyar, en lo posible, su realización; f) controlar y fiscalizar las actividades de las entidades existentes en la demarcación, independientemente de su nivel de subordinación”. (ANPP, 2000).

No concernente a atores como Delegados e Conselheiros do OP, também são apreciadas funções que refletem estratégias para empoderar a cidadania diante os processos decisórios nos territórios, contribuindo assim para a criação de um bem

${ }^{19}$ Artigos 57 e 58. 
comum através de proximidades entre o governo e a sociedade civil. As atribuições que são outorgadas aos Delegados do OP no artigo 32 do RI são as seguintes:

\begin{abstract}
"São atribuições dos (as) Delegados (as): a) Conhecer, cumprir e fazer cumprir o presente Regimento Interno. c) Apoiar os (as) Conselheiros (as) na informação e divulgação para a população dos assuntos tratados no COP. d) Acompanhar o Plano de Investimentos, desde a sua elaboração até a conclusão das obras. e) Compor as Comissões Temáticas (exemplo: Saneamento, Habitação e Transportes) com o objetivo de debater a construção de Diretrizes Políticas. As Comissões Temáticas poderão desdobrar-se em Comissões de acompanhamento de obras. f) Propor e discutir os critérios para seleção de demandas nas microrregiões e Regiões da Cidade g) Participar das Comissões de Fiscalização e Acompanhamento de obras, desde a elaboração do projeto, licitação até sua conclusão. h) Encaminhar demandas das suas comunidades em prazo determinado pelo Fórum de Delegados (as), Regional ou Temático. i) Votar e defender interesse comum em nome de sua comunidade. j) Votar as propostas de pauta e demandas do Orçamento Participativo". (PMPA, 2015, p. 18-19).
\end{abstract}

Orientadas a convertê-los em agentes ativos na promulgação das capacidades da sociedade civil para incidir na configuração da realidade social e política, o conjunto de normativas indicadas abaixo constituem algumas dessas evidencias:

"São Direitos dos Conselheiros (as): a) Votar e ser votado em eleições de representação do Conselho; b) Participar com direito a voz e voto nas reuniões do COP, nas Plenárias e reuniões da sua Região ou Temática; c) Exigir o cumprimento das resoluções e decisões tomadas pelo COP; e) Solicitar esclarecimentos e retorno sobre temas e demandas, investimentos, serviços, ações do Governo que suscitem dúvidas de interesse de sua Região ou Temática”. (PMPA, 2015, p. 17).

Demonstradas algumas características comuns entre o OP e a AMPP, como experiências democráticas relativamente similares e localizadas em contextos diferentes (comparação globalizante conforme foi assinalado anteriormente), ressalta-se a projeção empírica dessas experiências, especialmente no que concerne à forma em que na prática se materializa o princípio da cidadania como protagonista na configuração da realidade social e política, como declarado oficialmente. 
As estratégias e ferramentas analíticas que poderiam ser aplicadas para examinar em Cárdenas e em Porto Alegre a correspondência entre as "normativas" e o "real", em termos democráticos, são diversas. No entanto, diferentes tipos de teorias albergam propostas epistemológicas mais viáveis nesse sentido. Tal viabilidade sustenta-se nas suas especializações em propor atributos para entender e analisar as relações entre o Estado e a sociedade civil, sob a base do princípio em questão que, ao menos como doutrina, define a lógica de funcionamento do OP e da AMPP.

Entre essas tipologias teóricas estão, por exemplo, as teorias sobre a Democracia, cuja gênese esteve precisamente vinculada à ideia do poder do povo na configuração das sociedades. Assim sendo, com a intenção de aprofundar nas possíveis estratégias que facilitem a análise sobre a correspondência mencionada, resulta imprescindível abordar os principais atributos dessas teorias, o que será feito no capítulo a seguir. 


\section{DEMOCRACIA E DEMOCRATIZAÇÃO}

Os primeiros significados do termo "democracia" emergem da antiga Grécia e se configuram a partir da conjugação das palavras demos (povo) e kratia (governo). Com o passar do tempo, o sentido do termo Democracia cuja gênese está localizada na Grécia antiga foi se transformando consideravelmente até surgir teorizações contemporâneas, cujos conteúdos mostram concepções bem particulares. Essas teorizações não têm sido somente baseadas nas falhas e sucessos das históricas experiências democráticas, conforme relata SARTORI (1994); também têm estado superpostas aos interesses e às experiências e ferramentas dos autores que sobre ela tem discorrido.

Como resultado, atualmente se visualiza uma diversidade de práticas democráticas e posicionamentos conceituais sobre a democracia, abrindo um amplo espectro de conteúdos conceituais muitas vezes excludentes entre si e distantes da gênese da democracia enquanto empoderamento da sociedade civil. Além disso, algumas dessas abordagens sobre o conceito em questão também apresentam contradições no seu interior, principalmente na relação entre as suas propostas para empoderar a população e os resultados derivados dessas propostas.

Diante desse cenário contraditório do ponto de vista teórico, examinar a realidade política sobre a base do conceito em questão constitui um desafio analítico. Esse desafio exige cautela na definição das ferramentas teóricas para analisar essa realidade, como também no estabelecimento de generalizações referentes ao que na prática é um país democrático e o que não é, principalmente quando se trata de realidades sujeitas a sistemas ou regimes políticos contrapostos.

As ações que surgem em presença dessa problemática são diversas, podendo desembocar em resultados científicos com variáveis graus de objetividade e eficácia analítica. Uma dessas ações pode ser a análise das realidades democráticas sobre a base das teorias hegemônicas, que enfatizam na necessária 
existência de direitos, procedimentos, liberdades e etc., como sinônimo de democracia. Não obstante, é necessário antecipar que muitas dessas abordagens ainda têm limitações para representar a ampla gama de práticas democráticas contemporâneas, que sobrepassam certas tentativas de definição hegemônica sobre a democracia, seja como conceito ou como forma de organização da sociedade.

Os argumentos anteriores demonstram a presença de uma problemática empírica, pois cada vez mais se visualizam insatisfações sociais por causa das incoerências entre decisões tomadas pelos governos e interesses populares, em países e regimes que, de acordo com essas teorias, são considerados democráticos. Essas insatisfações indicam como principal entrave o fato de que a democracia como conceito tem sido utilizada para definir e legitimar uma realidade que não corresponde com a essência que tem marcado seu surgimento. Situação essa que, para autores como Raymond Williams, constituiria um problema histórico ainda não resolvido que deriva da mutação dos nossos conceitos básicos:

"Cuando los conceptos básicos -los conceptos, como se dice habitualmente, de los cuales partimos- dejan de ser conceptos para convertirse en problemas- no problemas analíticos, sino problemas históricos que todavía no han sido resueltos-, no tiene sentido prestar oídos a sus sonoras invitaciones o a sus resonantes estruendos. Si podemos hacerlo debemos limitarnos a recuperar la esencia en la que se han originado sus formas". (WILLIAMS, 1980, p. 21).

Perante as citadas concepções sobre a democracia que refletem suas contrariedades internas e as insatisfações políticas em países considerados democráticos (PRZEWORSKI, 2010; LATINOBARÓMETRO, 2015), a alternativa proposta neste trabalho parte da sugestão de Raymond Williams de recuperar a essência na qual se originaram as formas do conceito examinado. Essa essência consiste na ideia do maior empoderamento possível da sociedade civil na 
construção da realidade social, num contexto de distribuição de poder entre as sociedades políticas e civis ${ }^{20}$.

Para recuperar essa essência que determinou a gênese do conceito de democracia e que, de um modo ou de outro, se mantém latente em diferentes propostas conceituais, no presente trabalho se opta por tentar transcender essas teorias hegemônicas, embora elas constituam referentes importantes para a configuração da análise. Dito isso, se pretende propiciar uma ferramenta analítica que permita analisar os processos democráticos, examinando não simplesmente os procedimentos democráticos existentes, como também o poder que mediante eles a sociedade civil adquire para incidir na configuração da realidade que lhe incumbe.

Para desenvolver tal ferramenta, no presente capítulo se sistematizam diferentes perspectivas de autores envolvidos com a teorização sobre a Democracia e a Democratização. Logo depois, discute-se as noções relativas à democratização, destacando sua importância para a análise da democracia como processo.

\subsection{Abordagens sobre a democracia: Joseph Schumpeter e Robert Dahl}

Das abordagens sobre a democracia em contexto contemporâneo, têm destaque as propostas de Joseph Alois Schumpeter (1883-1950) e de Robert Dahl (1915-2014), considerados como uns dos primeiros representantes da abordagem politológica, denominada por SARTORI (1994) como enfoque empírico da democracia.

\footnotetext{
${ }^{20}$ Esse princípio está baseado na ideia de "poder do povo" que surge na Antiga Grécia. Apesar das conhecidas limitações para materializar essa ideia na época, neste trabalho se considera importante retomá-la, não só como base de uma concepção ideal da relação entre Estado e sociedade civil (democracia), senão como ferramenta de crítica sobre a correspondência entre teoria e empiria democrática. Isso tudo, reconhecendo as reflexões que vários autores fizeram em relação às limitações para materializar esse principio no contexto atual (SCHUMPETER, 1961; PRZEWORSKI, 2010; ACOSTA, 2014).
} 
Schumpeter assume uma ideia sobre democracia que em certa medida limita a materialização dos ideais precursores relativos à distribuição do poder entre o povo e o Estado. A sua postura é uma crítica à definição clássica de democracia do século XVIII, entendida como um arranjo institucional para chegar a certas decisões políticas, orientadas a realizar um bem comum sobre a base das vontades do povo (SCHUMPETER, 1961).

Ao problematizar a definição clássica sobre "um governo do povo" e questionar a possibilidade de se estabelecer um "bem comum para todos", Schumpeter não só desenvolve uma noção empírica de democracia, mas também lhe outorga um sentido basicamente procedimental ${ }^{21}$. Sendo assim, entende a democracia, pelo seu método representativo liberal. Segundo o autor, "o método democrático é um sistema institucional para a tomada de decisões políticas, no qual o indivíduo adquire o poder de decidir mediante uma luta competitiva pelos votos do eleitor" (SCHUMPETER, 1961, p. 329).

Ao destituir o estudo da democracia da definição de objetivos últimos, Schumpeter estabelece as bases de uma abordagem analítica adequada às realidades democráticas. Segundo o autor, "estamos agora em posição algo melhor porque, até certo ponto, decidimos frisar o 'modus procedendi', cuja existência ou inexistência é fácil de verificar na maioria dos casos" (Idem).

Outro aspecto consiste na importância outorgada à liderança dentro desses processos de luta competitiva, pois em determinados momentos os líderes podem estimular as latentes vontades coletivas, assim como os corpos coletivos atuam fundamentalmente pela aceitação da liderança. Em relação a esta problemática, o presente autor coloca ainda certa noção de justiça, ao afirmar que o governo deve ser acessível àqueles indivíduos concorrentes que tenham mais votos e maior apoio popular.

\footnotetext{
${ }^{21}$ Procedimental por considerar basicamente que a existência de procedimentos é suficiente para uma democracia.
} 
Um terceiro aspecto é a relação que a concepção anterior estabelece entre democracia e liberdade. Esta última é entendida como uma esfera de autogoverno individual que, segundo o autor, pelo menos no plano político poderia implicar maiores margens de liberdade de expressão, sobre a base da livre concorrência dos indivíduos à liderança (Idem: 330).

Por último, Schumpeter expressa também que a clássica vontade do povo como base da democracia constitui em si mesma um obstáculo para a execução de tal vontade. Isso se justificaria por conta da deturpação ou dificuldade que, em termos de decisões, envolvem os desejos dessa maioria (pela extensão em números), que não precisamente constitui o povo (Idem: 332) ${ }^{22}$.

Um enfoque similar a esse, conhecido como "agregativo", desenvolve também o cientista político estadunidense Robert Dahl, com as suas ideias sobre a democracia e a "poliarquia". Para esse autor, a democracia constitui um ideal de organização da sociedade a partir do qual se orientam as práticas governamentais (Dahl, 2005), favorecendo um conjunto de consequências desejáveis:

“(1) evitar la tiranía de gobiernos autócratas, (2) garantizar derechos esenciales, (3) asegurar un mayor ámbito de libertad personal, (4) promover la autodeterminación y (5) la autonomía moral, (6) estimula el desarrollo humano, (7) proporciona protección a intereses personales, (8) garantiza igualdad política y, además, agrega este autor que la definición moderna de democracia se orienta hacia la búsqueda de la paz y la prosperidad". (Dahl, 2001, p. 58).

Nesse "ideal hipotético" que constitui a democracia, Dahl (2005) concebe a forma de governo intrinsecamente associada ao aumento de oportunidades de participação e contestação pública nos assuntos políticos, por parte de um maior número possível de indivíduos e grupos sociais. Isto se traduziria em uma ampliação da inclusão das preferências individuais na política e no

\footnotetext{
${ }^{22}$ Uma das críticas a este pensador é que ele não prevê os efeitos dessas lideranças criadas por competência desleais ou fraudulentas ou por insurreição militar na democracia. A outra é a contradição que implica a sua defensa das eleições (governo deve ser entregue aos indivíduos concorrentes que contam com mais votos), frente a um fictício poder do povo. Esta solução não resolve o problema, pois seguem sendo parciais às vontades coletivas.
} 
desenvolvimento de um governo responsivo frente às preferências dos cidadãos considerados politicamente iguais. O autor afirma, em seu clássico Poliarquia, que

\begin{abstract}
“(...) gostaria de reservar o termo democracia para um sistema político que tenha como uma de suas características, a qualidade de ser inteiramente, ou quase inteiramente responsivo a todos os seus cidadãos (...). Parto do pressuposto de que uma característica-chave da democracia é a continua responsividade do governo às preferências de seus cidadãos, considerados como politicamente iguais (...). Consideremos, então, a democratização como formada por pelo menos duas dimensões: contestação pública e participação". (DAHL, 2005, p. 25-26, 29).
\end{abstract}

Por outro lado, a poliarquia possui conteúdos diferenciados, embora relacionados, com a democracia. Para Dahl, ela é a condição mais próxima e uma aproximação real e imperfeita do modelo ideal de democracia, além de uma ferramenta analítica em sim mesma:

\footnotetext{
“(...) é importante manter a distinção entre democracia como um sistema ideal e os arranjos institucionais que devem ser considerados como uma espécie de aproximação imperfeita de um ideal, e a experiência mostra, acredito, que, quando o mesmo termo é usado para ambos, intrometem-se, na análise, uma confusão desnecessária e discussões semânticas essencialmente irrelevantes" “(...) tal concepção [democracia] serviu como um ideal ou parte de um ideal para muita gente (...). Como sistema hipotético, ponto extremo de uma escala, ou estado de coisas delimitador, ele pode (...) servir de base para se avaliar o grau com que vários sistemas se aproximam deste limite teórico". (DAHL, 2005, p. 26, 31-32).
}

Sobre a base dos dois conceitos referidos, e com objetivo de brindar elementos para medir o grau de democratização dos sistemas políticos, Dahl apresenta duas dimensões fundamentais do processo que eles implicam. Essas dimensões são: contestação pública e participação. Ambas as dimensões são descritas através de um conjunto de variáveis agrupadas em oportunidades plenas e garantias institucionais. Portanto, fazendo uma conexão entre o princípio de poder do povo (ou empoderamento dos cidadãos) e as duas dimensão propostas por Dahl, se percebe que esse poder do povo sobre a configuração da política consiste no 
conjunto de oportunidades e garantias que possa ter essa população para exercer formas de contestação pública e de participação.

Num primeiro momento as oportunidades que, segundo DAHL (2005), todos os cidadãos devem ter para garantir o processo anterior são: 1) oportunidades para formular as suas preferências; 2) para expressar as suas preferências aos seus concidadãos e 3) para ter as suas preferências igualmente consideradas na conduta do governo, sem discriminação de conteúdo ou de origem das preferências.

No que se refere às garantias institucionais que materializariam tais oportunidades, enumeram-se as seguintes: 1) liberdade de formar e se aderir a organizações; 2) liberdade de expressão; 3) direito de voto; 4) direito de líderes políticos de disputar apoio e votos; 5) fontes alternativas de informação; 6) elegibilidade para cargos públicos; 7) eleições livres e idôneas e 8) instituições para fazer com que as políticas governamentais dependam de eleições e de outras manifestações de preferências.

Contudo, em trabalho posterior intitulado "On Democracy" $"$, DAHL (1998) atualiza essas oportunidades e mantém as mesmas garantias institucionais, insistindo que elas servem como ferramentas analíticas para identificar os sistemas poliárquicos e democráticos. Como oportunidades que devem brindar estes sistemas, o cientista político norte americano estabelece as seguintes: 1) participação efetiva; 2) igualdade de voto; 3) realização de um entendimento esclarecido; 4) exercício de um controle definitivo sobre a planificação e 5) inclusão dos adultos.

A participação efetiva refere-se às oportunidades dos cidadãos para expressar os seus pontos de vista sobre a adoção de políticas antes de serem executadas. A igualdade de votos alude às oportunidades iguais e efetivas dos cidadãos para votar pelas políticas a serem adotadas. Por entendimento esclarecido, Dahl assume as oportunidades para que os cidadãos conheçam a

\footnotetext{
${ }^{23}$ Versão em português: “Sobre a democracia”. Tradução de Beatriz Sidou. Editora UnB, Brasília, 2001.
} 
existência de políticas alternativas e suas respectivas consequências prováveis. O controle definitivo sobre a planificação se refere às oportunidades para decidir as questões a serem incluídas neste processo e o modo como se incluiriam. Por último a inclusão dos adultos faz alusão a todos os adultos residentes como beneficiários das oportunidades descritas (DAHL, 1998).

Considerando as propostas dos autores até este momento analisados, podem-se destacar várias questões em relação ao propósito aqui explícito de analisar os processos democráticos, insistindo na distribuição de poder entre governos e cidadãos para incidir na configuração da realidade que lhes compete. Basicamente, em ambos os pensadores estão presentes a ideia de que a democracia está vinculada ao empoderamento dos cidadãos nos processos decisórios ${ }^{24}$, conforme a gênese desse conceito. Não obstante, as capacidades de materialização desse princípio mediante as instituições e procedimentos propostos por esses autores, assim como as estratégias analíticas para identificar a existência do citado princípio, não resultam suficientes.

No caso de Dahl especificamente e dialogando com algumas críticas sobre a sua obra (BERNS, 1958; DUNCAN y LUKES, 1963; CONNOLLY, 1967; EDELMAN, 1970 e LEE, 1991, entre outros), se percebe que o conjunto de garantias e oportunidades (Quadro 1) que devem existir para que determinados sistemas políticos sejam considerados poliárquicos ou democráticos ainda é limitado para potenciar uma concepção e uma prática democrática baseada no mencionado princípio de empoderamento dos cidadãos. Essa limitação é visível em experiências de sistemas políticos onde, apesar da existência de tais garantias e oportunidades, contraditoriamente ainda são deficientes os graus de poder dos cidadãos sobre importantes decisões que configuram a realidade social. Especialmente, as disputas pela democratização do Estado continuam latentes,

\footnotetext{
${ }^{24}$ Para Schumpeter a democracia é o poder dos indivíduos para decidir e para Dahl são oportunidades de contestação e participação, conduzindo para um a existência de um governo responsivo.
} 
apesar da existência de poliarquias, sobretudo na região das "veias abertas" 25 (MILLS, 1956/58; ACKERMAN, 2006; PRZEWORSKI, 2010).

Quadro 1- Garantias e oportunidades de um sistema democrático - Dahl

\begin{tabular}{|c|c|}
\hline Garantias institucionais & $\begin{array}{c}\text { Oportunidades que devem brindar } \\
\text { esses sistemas }\end{array}$ \\
\hline $\begin{array}{l}\text { 1. Liberdade de formar e se aderir a } \\
\text { organizações. }\end{array}$ & 1. Participação efetiva. \\
\hline 2. Liberdade de expressão. & 2. Igualdade de voto. \\
\hline 3. Direito de voto. & 3. Realização de entendimento esclarecido. \\
\hline $\begin{array}{l}\text { 4. Direito de líderes políticos de disputar } \\
\text { apoio e votos. }\end{array}$ & $\begin{array}{l}\text { 4. Exercício de controle definitivo sobre a } \\
\text { planificação. }\end{array}$ \\
\hline 5. Fontes alternativas de informação. & 5. Inclusão dos adultos. \\
\hline 6. Elegibilidade para cargos públicos. & \\
\hline 7. Eleições livres e idôneas. & \\
\hline $\begin{array}{l}\text { 8. Instituições para fazer que políticas } \\
\text { governamentais dependam de eleições e } \\
\text { de outras manifestações de preferências. }\end{array}$ & \\
\hline
\end{tabular}

Fonte: Hans Carrillo Guach com base em DAHL (2001).

Além disso, se esses aspectos fossem suficientes, se concluiria que nas experiências democráticas municipais em Cárdenas e em Porto Alegre existe empoderamento dos cidadãos nos marcos de uma aproximação entre o Estado e a sociedade civil, que supõe a tomada de decisões como um processo dirigido por ambas as frações em igualdade de condições. Isso implicaria que nessas localidades existe uma organização da sociedade local que oferece suporte para o exercício de poder dos indivíduos mediante a eleição de representantes. Por outro lado, essa organização sustentaria oportunidades para a contestação e participação, assim como para um governo responsivo (DAHL, 2001, 2005).

No entanto, não são desconhecidas as insatisfações sociais e políticas da população nesses territórios, junto com as limitações para a configuração de uma realidade acorde com certos interesses fundamentais dessa população. Esses aspectos, junto com as restrições democráticas reconhecidas no nível mundial, sugerem não só uma possível proposta diferenciada de organização da sociedade,

\footnotetext{
${ }^{25}$ Referência à denominação que usa GALEANO (2010) para descrever América Latina.
} 
mas também reclamam outra perspectiva de análise para identificar e entender a democracia, como forma de distribuição de poder.

\subsection{A democracia participativa na visão de Macpherson e Habermas}

Diante dessas teorizações, têm-se produzido outras propostas teóricoconceituais relativas ao conceito de democracia. Uma delas é a conhecida democracia participativa, que tem na sua base a ideia de participação. Essa ideia emerge no decênio de 1960 como consigna dos movimentos estudantis da Nova Esquerda (MACPHERSON, 2003), mas obteve maior florescimento na década de 1970, por conta do surgimento de profundos questionamentos na ordem social e política que sustentaram importantes demandas de participação cidadã em distintas nações. Segundo Pateman,

"During the last few years of the 1960s, the word 'participation' became part of the popular vocabulary. This took place under the impetus of demands, notably from students, for new areas of participation to be opened up. (...). The popularity of the concept provides a good reason for devoting some attention to it, but more importantly the recent upsurge to demands more participation raises a central question of political theory (...) this preoccupation has its origins in the contrast drawn between "democracy" and "totalitarianism" as the only two alternatives available in the modern world”. (PATEMAN, 1970, p. 1-2).

A abordagem participativa de democracia constituiu uma resposta às noções minimalistas desenvolvidas por Schumpeter, Dahl, etc. Mas, simultaneamente, é considerada para muitos autores como complementar ao enfoque procedimental, pois considera a combinação de procedimentos representativos e participativos com princípios básicos do fenômeno político e social em questão (VERGARA, 2005).

Considerando a ênfase nos mecanismos de participação cidadã como facilitadores da democracia, PATEMAN (1970) assume que uma das ideias 
centrais deste enfoque (seguindo autores como Rousseau, John Stuart Mill y G.D.H. Cole), é que os indivíduos e as instituições representativas não devem se conceber de maneira isolada no funcionamento democrático das sociedades. É indispensável considerar outras esferas sociais onde se desenvolvam necessárias atitudes individuais e qualidades psicológicas, através da participação de todos os cidadãos nos espaços decisórios do Estado.

De outro lado, segundo COHEN y ARATO (2002), os principais defensores da democracia participativa (Crawford B. Macpherson; Carole Pateman; David Held; Jürgen Habermas, etc.), não é só primordial reduzir as lacunas entre a sociedade civil e a sociedade política através da criação de espaços públicos, como também, e não isento de críticas $^{26}$, o distanciamento, de certo modo, desse modelo de democracia procedimental (ou formal) analisado anteriormente que, segundo David Held (1987), também se conhece como "democracia elitista competitiva".

Em relação às reflexões dos citados representantes da democracia participativa, é pertinente acrescentar que, embora existam pontos comuns entre eles, também existem argumentos particularizados. Uma primeira proposta teóricoconceitual a ser analisada é a que apresenta Macpherson, que coloca elementos pertinentes a respeito do princípio de empoderamento da sociedade.

$\mathrm{Na}$ sua obra "La democracia liberal y su época", Macpherson relata a evolução da democracia desde o século XVIII até a atualidade e apresenta quatro modelos de democracia. Destes quatro modelos, o último - "Democracia como participación" - condensa a sua proposta conceitual, assumindo que democracia significa mais participação dos cidadãos nas decisões políticas.

Para a materialização desta tipologia de democracia, MACPHERSON (2003) admite a necessidade de cumprir com dois requisitos básicos, a partir de

\footnotetext{
${ }^{26}$ Alguns críticos consideram esta proposta utópica e antimodernista, entre outras questões, porque apontam à despolitização das formas representativas, dando centralidade aos partidos políticos.
} 
uma concepção dialética ${ }^{27}$. Baseado na importância de um maior sentimento de comunidade, o primeiro deles consiste em que as pessoas parem de se ver apenas como consumidoras, passando a se considerar e a agir como "entes" ativos no exercício e no desenvolvimento das suas próprias capacidades humanas. O segundo requisito consiste na necessária redução da desigualdade econômica e social. Junto com o cumprimento destes requisitos, o autor continua expondo a importância de executar dois possíveis modelos de organização social com vistas a uma democracia participativa.

O primeiro desses modelos é um sistema piramidal com uma democracia direta na base a nível local (comunidade, bairro, fabrica, etc.), onde teriam lugar debates diretos e decisões por consenso ou maioria, assim como posteriores eleições de Delegados. Esses delegados conformariam, portanto, conselhos ao nível territorial mais alto (municipal, regional, etc.) até chegar ao nível nacional. No nível nacional poderia existir um comitê do Conselho, cuja missão seria propor e estudar os temas de Estado mais importantes. MACPHERSON (2003) propõe três condições para que tal sistema seja executado corretamente: 1) evitar o perigo de contrarrevolução (caso Allende no Chile), mantendo uma autoridade central para tentar proteger o sistema; 2) evitar a produção e reprodução de grandes desigualdades econômicas, porque limitariam os níveis de responsabilidade do governo com os governados e provocariam modelos de democracias inviáveis e 3) evitar a apatia política do povo.

O outro modelo proposto por MACPHERSON (2003) combina a democracia direta (ou sistema piramidal) com a democracia indireta e sistema de partidos, como saída mais palpável frente a uma possível ineficácia do primeiro modelo. Este modelo democrático se baseia no rol dos partidos competitivos e a sua participação real, organizados de forma semelhante à experiência de Assembleias dos Soviets na antiga URSS (improvável segundo o autor), ou a partir

\footnotetext{
27 Em relação a esses princípios, Macpherson fala de um círculo vicioso que mostra uma concepção dialética sobre o assunto. Nesse sentido, expressa que a participação democrática não poderia ser materializada sem uma mudança previa na desigualdade social e na consciência. Mas, simultaneamente, essas mudanças nas desigualdades e na consciência não existirão se antes não houver um aumento da participação democrática (MACPHERSON, 2003).
} 
de um funcionamento piramidal dos partidos, em uma estrutura parlamentária ou de congresso.

Simultâneo a esses argumentos, Macpherson oferece outro elemento que conveniente para a uma concepção de democracia como a que se pretende utilizar no presente trabalho. Especificamente, esse elemento é a combinação de aspectos da democracia procedimental com a participativa.

Essa tentativa do autor marca um indício da necessidade de conceber a democracia por meio desta perspectiva, pelo menos no seu plano ideal. Haveria, contudo, que proceder com cuidado na escolha de elementos de ambas as propostas para se combinar, com o objetivo de potencializar a essência da democracia em sua maior expressão: o povo como protagonista do poder e da política, através da identificação e da integração entre o governo e a sociedade civil.

Por outro lado, esse cuidadoso proceder também sugere a valoração de outros argumentos que, mesmo estando inseridos nesta linha de pensamento (democracia participativa), têm as suas particularidades. Um exemplo pode-se encontrar na proposta de Jürgen Habermas com a sua teoria da ação comunicativa, acrescentando um sentido deliberativo à democracia.

Um dos pontos básicos do enfoque deliberativo é que a democracia se associa com a ideia de que os processos de tomada de decisões se alcançam por meio da discussão entre cidadãos livres e iguais, num contexto de comprometimento dos participantes com os valores de racionalidade $\mathrm{e}$ imparcialidade (ELSTER, 2001). Associada a esta noção de democracia, Habermas defende também uma imbricação entre diferentes enfoques sobre a democracia. Nesse sentido, ele tenta mediar entre os fundamentos da democracia liberal como proteção dos direitos individuais e aqueles fundamentos republicanos, que mantém a primazia dos direitos de participação política: 
"La teoría del discurso, que asocia al proceso democrático connotaciones normativas más fuertes que el modelo liberal, pero más débiles que el modelo republicano, toma de ambas partes elementos y los articula de una forma distinta y nueva". (HABERMAS, 1998, p. 374).

Desse modo, HABERMAS (1998) reconhece que a democracia deliberativa não é independente de procedimentos. Ela depende significativamente de procedimentos e de certos pressupostos comunicativos que permitiriam a institucionalização do discurso político. Estas questões motivaram SARTORI (2003) a dizer que a democracia participativa não é uma alternativa à democracia representativa e sim uma modalidade complementar que, por si sozinha, resultaria inoperante e dissolvida em grandes comunidades.

Por conseguinte, para HABERMAS (1998, p. 373) a democracia se entende como uma espécie de "auto organización política de la sociedad en su conjunto" porque os cidadãos, conscientes da sua autodeterminação política, operam através da vontade coletiva. Aliás, em termos práticos, HABERMAS (1998) insiste que este modelo deliberativo não depende exclusivamente de uma cidadania capaz de agir coletivamente. Ao mesmo tempo, está sujeito à institucionalização dos correspondentes procedimentos e pressupostos comunicativos, assim como à interação de deliberações institucionalizadas com opiniões públicas desenvolvidas informalmente.

Essa concepção tem implícitos determinados elementos teóricos, que ao nível empírico, podem orientar a análise sobre a existência de certas formas de democracia. No seu interior, ela estabelece uma conexão entre considerações pragmáticas, compromisso entre cidadãos e discursos de autoentendimento e justiça, ao mesmo tempo em que fundamenta a ideia de que, com base num fornecimento de informações objetivas a respeito de certas problemáticas sociais, podem-se conseguir resultados favoráveis em termos democráticos. 


\begin{abstract}
"Este procedimiento democrático establece una conexión interna entre las consideraciones pragmáticas, los compromisos, los discursos de auto-entendimiento y los discursos relativos a justicia y fundamenta la presunción de que bajo las condiciones de un suficiente suministro de información relativa a los problemas de que se trate y de una elaboración de esa información ajustada a la realidad de esos problemas, se consiguen resultados racionales, $\mathrm{o}$, respectivamente resultados 'fair'”.(HABERMAS, 1998, p. 372).
\end{abstract}

Fazendo um balanço dos conteúdos referentes ao enfoque da democracia participava, necessita-se retomar alguns dos seus elementos teóricos, que podem favorecer a intenção declarada no presente estudo de analisar os processos democráticos, insistindo na distribuição de poder entre governos e cidadãos para incidir na configuração da realidade que lhes compete.

Um aspecto comum entre Macpherson e Habermas é que a democracia está associada a uma maior relação entre decisões políticas e participação popular dos cidadãos nesses processos decisórios. Para materializar esse processo, Macpherson insiste na importância de certas dimensões subjetivas e sociais $^{28}$, enquanto que Habermas insiste no debate deliberativo. Assim sendo, as duas propostas resultam mais viáveis como ferramentas analíticas da democracia como processo.

Sem esquecer algumas das criticas a esse enfoque ${ }^{29}$, a proposta habermesiana apresenta elementos que podem facilitar a identificação empírica de outras questões da democracia, principalmente ao considerá-la mais como processo de empoderamento do que como forma de organização social. Entres esses elementos se destacam o processo de institucionalização de procedimentos democráticos ou deliberativos, a prestação de informações objetivas sobre as decisões, assim como as capacidades para apresentar, discutir, aceitar o rebater os argumentos a favor ou em contra das alternativas de decisão.

28 Para lembrar, do ponto de vista subjetivo, Macperson insiste na importância do imaginário dos indivíduos relativos a seus papéis como entes ativos no processo democrático, enquanto que do ponto de vista social destaca as desigualdades sociais e econômicas.

${ }^{29}$ Uma das principais críticas é que nem sempre as oportunidades de participar garantem uma real incidência dos cidadãos nos processos decisórios. Existem fatores sociais e econômicos que incidem nas capacidades dos cidadãos para participar. Além disso, os processos deliberativos podem se tornar uma dificuldade na tomada de decisões, devido à quantidade de pessoas e à diversidade de critérios. 
Entretanto, é indispensável submeter as potencialidades do enfoque às críticas como, por exemplo, a de sua insuficiência. Os elementos da democracia deliberativa (apresentados no Quadro 2, abaixo) são restritos a um aspecto do fenômeno que se distancia da observação das relações entre o Estado e os cidadãos, implicando o empoderamento desses últimos nos processos decisórios sobre os assuntos públicos. Para conseguir uma abordagem mais integral sobre as reais capacidades dos cidadãos para incidir nas decisões sobre as quais se configuram as suas realidades, é necessário constituir uma perspectiva que integre componentes característicos da análise procedimental (que envolvem questões como a responsividade e o controle público, dentre outras).

Quadro 2- Democracia Deliberativa: alguns elementos teóricos

\begin{tabular}{|c|}
\hline — Entes ativos e não simples consumidores \\
\hline - Mais participação nas decisões políticas \\
\hline • Institucionalização de procedimentos \\
\hline - Institucionalização de pressupostos comunicativos. \\
• Discursos de auto-entendimento e justiça. \\
\hline - Conexão entre considerações pragmáticas e compromissos entre cidadãos. \\
\hline - Oportunidades para prestação de informações objetivas. \\
\hline Possibilidades de apresentar, discutir, aceitar o rebater argumentos e alternativas de \\
decisão.
\end{tabular}

Fonte: Hans Carrillo Guach com base em HABERMAS (1998, 2005)

Para constituir um instrumento analítico, no entanto, ainda é necessário considerar dois entraves. O primeiro é que uma bricolagem de conteúdos poderia corromper a "identidade" de ambas as concepções teóricas, devido às suas possíveis contradições. Em segundo lugar, ela deve fundamentar uma análise que transcenda a ênfase na democracia como existência de oportunidades (para determinados processos). Uma análise desse tipo enfrentaria limitações para compreender as lógicas de dominação entre cidadãos e governos, que moldam as formas de empoderamento desses últimos. Especialmente, deve-se considerar que as atuais formas de autoritarismo sobrevivem entre os requisitos mínimos de um 
regime democrático (BEHREND, 2012), que facilitam o encobrimento dessas capacidades restritas de empoderamento dos cidadãos.

Dessas limitações, deriva a necessidade de enfatizar a análise das relações democráticas entre o Estado e a sociedade civil, a partir das capacidades dos cidadãos e nos resultados emergidos dessas relações, segundo os contextos históricos. E quando se trata dessas capacidades, sugere-se enfatizar no papel da cidadania para obrigar aos atores governamentais (detentores de políticas prejudiciais), a se retroalimentar das propostas daquela população que se opõe às consequências resultantes das suas políticas (WHITEHEAD, 2002). Essa sugestão constitui uma saída viável ao fato de que nem sempre as oportunidades que sistemas políticos "democráticos" oferecem aos cidadãos para controlar, participar, deliberar etc. se convertem em capacidades reais para materializar as demandas e necessidades dos cidadãos nas decisões adotadas.

Dessa forma, as oportunidades reais de integrar certos conteúdos de ambas as propostas para facilitar uma análise mais integral da realidade democrática deve superar o caráter atemporal, estável e universal que alguns autores atribuem à democracia como ferramenta analítica (WHITEHEAD, 2011). Essa ação poderia ser facilitada recorrendo-se a teorizações concebidas a partir de uma perspectiva mais dinâmica e dialética, que valorize análises de tipo hermenêutico, como forma de aprofundar nas complexidades da realidade democrática (GADAMER, 1999).

Justamente, em conexão com esses atributos, tem-se desenvolvido algumas posturas teóricas referentes a outro conceito que, se bem se semelha à Democracia por seu caráter polissêmico, ao mesmo tempo adquire conotações diferenciadas, como estratégia epistemológica para a análise das relações entre governos e governados. Nesse caso, trata-se das teorizações sobre a Democratização, cujos conteúdos configuram o tópico a seguir. 


\subsection{A democratização: fundamentos para uma abordagem dinâmica sobre o objeto de estudo.}

O conceito de Democratização tem uma notável interrelação com as noções sobre democracia, embora adquira diferentes conotações teóricas e conceituais segundo a variedade de autores. Uma das conotações que esse conceito adquiriu está ligada ao fenômeno da transição de formas organizativas da sociedade, particularmente quando se refere à transição de governos denominados não democráticos (ou com limitações em termos democráticos) para governos democráticos (HUNTINGTON, 1991; GIBSON, 2009; KING, LIEBERMAN, RITTER and WHITEHEAD, 2009; WHITEHEAD, 2011; BEHREND, 2012).

Outra conotação foi fruto de uma visualização mais clara sobre a necessidade de uma construção democrática, diante de realidades marcadas por desigualdades sociais, problemas ambientais e pobreza, além de práticas e estilos políticos contraproducentes para a democracia imaginada (PNUD, 1994). Tal visualização assentou as bases de novos horizontes analíticos e conceituais nos anos 1990, submergida consequentemente numa extenuação do entusiasmo pela democracia, advinda do derrocamento das ditaduras na América Latina.

Relacionados com essas visualizações, muitos desses novos horizontes estiveram comprometidos em diferentes tentativas de reajustes teóricos e conceptuais, centradas num objetivo bem concreto. Esse objetivo era, sobretudo, originar novas categorias analíticas que aumentassem as capacidades para apreender as lógicas dos processos democráticos e as contradições entre as democracias imaginadas e existentes, depois das suas instaurações.

Perante as tentativas de suscitar categorias analíticas que facilitassem uma compreensão mais aprofundada das complexidades que englobam os processos 
democráticos, surge o conceito de democratização ${ }^{30}$. O principal desafio com o qual nasce essa proposta (entre outras) é induzir outras noções teóricas e operacionais, para avaliar as limitações das práticas democráticas de maneira peculiar. E essa forma estaria, especificamente, caracterizada por dois elementos fundamentais associados à forma de abordar o termo democracia. O primeiro deles é assumir esse conceito como um processo que, transcendendo o comum aspecto organizativo ligado aos regimes políticos, não está isento de contradições e/ou retrocessos (VARGAS-CULLELL, 2011; IAZZETTA, 2013). O segundo é a ideia de entender a democracia não como um estado final predeterminado, senão como um processo de resultados de longo prazo e com finais abertos, que modifica constantemente as relações entre o Estado e a sociedade civil, assim como o equilíbrio entre as forças políticas e os poderes fáticos (WHITEHEAD, 2002).

Sobre a base dos anteriores argumentos, autores como O’DONNELL e SCHMITTER (1991) reconheceram, portanto, que o conceito em questão resulta mais adequado para analisar as práticas políticas e os processos democráticos. Desse modo, e concordando com o reconhecimento de contradições nas democracias contemporâneas, os estudiosos alegam que essa posição analítica da democratização se sustenta no fato de não ter como base conceitual e empírica a conquista definitiva de direitos democráticos e, além disso, é suscetível de sofrer retrocessos.

Tais retrocessos são considerados como um estado das experiências empíricas da democracia, não reconhecido usualmente pelas teorias sobre o conceito em questão. Consiste, segundo autores como TILLY (2010), na queda ou retrocesso no âmbito das capacidades para que os cidadãos incidam nas decisões políticas. Esse processo é chamado por Tilly de "desdemocratização", já que: "la democratización es un proceso dinámico que siempre permanece incompleto y corre permanentemente el riesgo de inversión, de desdemocratización" (TILLY, 2010, p. 29).

\footnotetext{
${ }^{30}$ Sem esquecer que também se podem enquadrar nesse contexto os conceitos de Qualidade da democracia e Consolidação democrática.
} 
Como conceito que implica dinamismo, na concepção de O’Donnell e Schmitter, a democratização aparece então estritamente vinculada ao conceito de cidadania, afirmando que "el principio rector de la democracia es el de ciudadanía (O’DONNELL e SCHMITTER, 1991, p. 249)”. Sendo assim, a relação concebida entre estes termos implica, no mínimo, que as pessoas sejam tratadas com igual consideração e respeito na formulação de opiniões coletivas. Igualmente sugere que os governantes ou atores que processam essas opiniões, tenham a obrigação de ser acessíveis a todos os membros do sistema político e responder por suas ações frente a eles (mulheres, jovens, homens, negros, pobres, etc.) (O’DONNELL e SCHMITTER, 1991).

Por outro lado, conceber a cidadania como principio reitor da democratização estabelece outras atribuições para governados e governantes. Os primeiros têm a obrigação de respeitar as opções que resultem da deliberação entre cidadãos iguais ante a lei. Os segundos têm o direito de agir com autoridade e, se for o caso, com medidas coativas, a fim de promover a eficácia dessas opções e proteger o sistema político de ameaças que perturbem o seu desenvolvimento, direito este que dever ser reconhecido e aceito pelos governados (Ibidem).

Tendo em consideração estes argumentos, O’DONNELL e SCHMITTER (1991) definem a democratização como um processo que envolve três componentes fundamentais:

- Processo onde as normas e os procedimentos da cidadania são aplicados a instituições políticas que antes estavam regidas por outros princípios (o controle coativo, tradição social, o julgamento dos especialistas ou as práticas administrativas).

- Processo onde essas normas e procedimentos podem ser ampliados de maneira que incluam indivíduos historicamente desprovidos dos direitos e as obrigações cidadãs anteriormente mencionadas. Alguns exemplos podem ser: pessoas que 
no pagam imposto, analfabetos, mulheres, jovens, minorias étnicas e residentes estrangeiros.

- Democratização como processo de expansão das normas e procedimentos da cidadania, de modo que novas problemáticas e instituições façam parte da vida cidadã. Exemplos destas são: organismos do Estado ou militares, organizações partidárias, associações de interesses particulares, empresas produtivas, entidades educativas, etc.

Norberto Bobbio também apresenta seus aportes para a compreensão teórica e conceitual da democratização, com alguns pontos de encontro com a anterior definição. Em sua concepção, as formas de empoderamento dos cidadãos para incidir nos assuntos que lhes incumbem não se materializam exclusivamente por falda de espaços, procedimentos e direitos. Por esses motivos, seu enfoque sustenta a ideia de que a democracia deve ser medida paulatinamente e a partir da conquista de novos espaços para a participação, num amplo sentido do conceito,

"Entendida en un sentido amplio, como la ocupación de nuevos espacios dominados hasta ahora por organizaciones de tipo jerárquico o burocrático, este proceso expansivo deberá continuar con la democratización del Estado y la democratización de la sociedad" (BOBBIO, 1994).

Como complemento dessa noção de Bobbio, Charles Tilly não só aporta a ideia sobre desdemocratização, assim como sugere outros elementos relativos a esse conceito. De acordo com esse autor, os graus da democracia dependem da medida em que o Estado age em conformidade com as demandas dos cidadãos. Assim, a democratização e seu reverso (desdemocratização) podem ser avaliadas a partir do aumento ou da diminuição de dita conformidade (TILLY, 2010).

Dessa forma, para Tilly, os processos de democratização e a avaliação dos graus de empoderamento prático dos cidadãos nos processos decisórios (como base desse conceito) se sustentam no papel do Estado como órgão encarregado de 
consultar os cidadãos sobre suas opiniões, necessidades, demandas, etc. No entanto, essa função do Estado não deve ser feita como estratégia de maniqueísmo democrático, e sim com o propósito de fazer com que diferentes grupos sociais consigam ver suas demandas, traduzidas nas práticas e políticas públicas do próprio Estado (TILLY, 2010).

Outro importante autor imerso na teorização sobre a democratização é Laurence Whitehead. Esse pensador defende a democratização como melhor ferramenta para entender a democracia como processo, reconhecendo igualmente que em certas ocasiões as formas de estudar as democracias não conseguem captar características importantes desse fenômeno. Situam-se, nesse cenário, as concepções sobre a "democracia política", conforme consta a seguir:

\begin{abstract}
"A menudo, las formas aceptadas de caracterizar las realidades sociales que ameritan ser estudiadas no logran capturar características importantes de los fenómenos que deben explicar Esto es particularmente cierto en el caso de los conceptos normativos muy abstractos cuyo significa- do proviene de asociaciones y presuposiciones socialmente construidas ex- ternas a la definición formal (el conocimiento "tácito" en el sentido de Polanyi, 2009). El concepto de "democracia política" reúne todas estas condiciones, y sus instancias ("concepciones") prácticas se alimentan intensamente de una variedad de realidades históricas que cambian con gran velocidad". (WHITEHEAD, 2011: 402).
\end{abstract}

Com referência a essa vantagem da democratização como ferramenta analítica, Whitehead argumenta que sua viabilidade está no fato de permitir a desconstrução daqueles regimes democráticos existentes, que se sustentam num modelo ideal e/ou mecânico predeterminado e supostamente consolidado, mediante a análise dos seus elementos defeituosos ou disfuncionais. Consequentemente, tal abordagem facilita uma maior ênfase no estado de "saúde" da democracia, como sistema adaptativo complexo, de construção social, governado por princípios reguladores que possibilitam sua readaptação a distintos ambientes, assim como o reajuste das suas funções. 
"En lugar de concentrarnos en los rasgos defectuosos o disfuncionales de los regímenes democráticos existentes partiendo de un modelo ideal (mecánico), este giro nos permite centrarnos en la salud de un sistema adaptativo complejo gobernado por principios reguladores que le posibilitan acomodarse a distintos ambientes externos y recalibrar las funciones internas". (WHITEHEAD, 2011: 403).

Sendo coerente com as facilidades empíricas que a utilização da noção de democratização oferece, Whitehead assume então uma singular postura conceitual, que permite complementar as abordagens até o momento descritas. Para esse autor, a democratização consiste num processo complexo em longo prazo, dinâmico e de final aberto, mais do que um estado final predefinido. É um processo que avança até um tipo de construção da sociedade e da política, essencialmente baseada em regras e em formas consensuais e participativas, onde não existe um ponto de chegada predeterminado nem universal.

\begin{abstract}
"El punto de partida teórico, elaborado en el capítulo I, es que la mejor manera de entender la "democracia" no es como un estado final predeterminado, sino como un resultado a largo plazo y con un final un tanto abierto, no sólo como un equilibrio factible sino como un futuro deseable e imaginario. Esta concepción significa que no puede haber una receta única para la democracia que se pueda aplicar en todo momento y lugar. (...). Las conclusiones clave son que necesitamos una concepción de la democracia "flotante pero anclada", y que la mejor manera de entender la democratización es como un proceso a largo plazo de construcción social (Whitehead, 2002:15, 19). He argumentado a favor de una concepción autopoiética de la democratización en tanto proceso de construcción política complejo, con final abierto y parcialmente reversible". (WHITEHEAD, 2011, p. 415).
\end{abstract}

Como processo de longo prazo e aberto que promove práticas de igualdade no exercício de direitos dos cidadãos para participar da configuração da sociedade e da política em particular, da anterior concepção sobre a democratização derivam uma série de características teóricas e empíricas que merecem ser discutidas, pois constituem elementos que podem facilitar a identificação desse processo na realidade social. 
Neste ponto de vista teórico, a ideia da democratização como processo aberto implica a possibilidade de um retrocesso, conforme também tinha reconhecido TILLY (2010). Nem sempre o avanço até uma sociedade de melhor (segundo seus contextos) com distribuição de poder entre o Estado e sociedade civil prevê um movimento linear e isento de contrariedades e retrocessos. Isso significa que o conceito também está aberto à reconsideração e revisão teórica e epistemológica, em função das experiências (WHITEHEAD, 2011). Assim, além de um possível retrocesso, também pode sofrer outros tipos de processos.

Como processo de construção da realidade e da política, a democratização ainda pode padecer de um estancamento em termos de empoderamento dos cidadãos. E associado a isso, também pode ser prejudicada por um enfraquecimento, por causa da forma como se inter-relacionam os distintos agentes sociais, em correspondência com os distintos fatores históricos, conjunturais, econômicos e até geopolíticos. Assim, diante dessas ameaças, um processo de democratização forte ou vigoroso deve ser capaz de minimizar ou erradicar os efeitos dos fatores ameaçantes, não por meio de relações participativas e de uma distribuição de poder artificial, mas sim por meio de relações entre as partes, baseadas em princípios de cooperação, diferenciação, complementaridade e deliberação intersubjetiva. $\mathrm{O}$ conjunto desses princípios seria os facilitadores da viabilidade dos processos democráticos, a partir de um complexo e constante processo adaptativo como base da sua manutenção e desenvolvimento. Conforme o autor,

“(...) las amenazas a ella surgen del debilitamiento de la capacidad del organismo para mantenerse en el tiempo: las defensas vitales se abandonan, ya que parecen innecesarias, o los órganos se emparchan y los emparchados son menos eficientes que los originales. (...) una democracia vibrante es aquella que tiene la mayor capacidad de domesticar las amenaza a un organismo que en términos generales es saludable podría simplemente serle difícil florecer en un ambiente superpoblado donde otros de su especie ocupan espacios más favorables y no la que logra sobrevivir detrás de un cordón sanitario artificial. La diferenciación, complementariedad, interdependencia y adaptabilidad son el sello distintivo de la autopoiesis. A diferencia del modelo autoritario de la vida política, el modo en que las células componentes y los órganos se desarrollan, especializan, comunican y cooperan es lo que determina en gran medida la viabilidad del organismo entero. Viabilidad, contagio, salud e hibridez son todos términos que pueden ser utilizados para esclarecer ciertos rasgos de la democratización que se 
refieren a la deliberación intersubjetiva entre ciudadanos libres". (WHITEHEAD, 2011, p. 410-416).

Considerando o conjunto de componentes que distintamente definem as variadas concepções sobre a democratização, apresenta-se a seguir os principais argumentos conceituais e operacionais que facilitarão a realização das análises na presente pesquisa, baseando-se não só nos pontos convergentes entre os argumentos dos autores tratados, mas também nas suas viabilidades analíticas em função das características do objeto de estudo.

Associado ao componente básico de assumir a democracia como processo, um primeiro elemento confluente a ser destacado é a ideia da democratização como forma de construção social da política, em correspondência com seus respectivos cenários históricos. Essa abordagem não poderia ser dispensada de uma concepção sobre a democratização, não só porque se configura como um aspecto comum entre a maioria das teorizações mostradas, senão porque, entre outras questões, implica a importância de prestar atenção às experiências cotidianas dos agentes envolvidos nos processos democráticos. Essas experiências, que WHITEHEAD (2011) pretende captar mediante sua abordagem "interpretativista", servirão sempre para oferecer novas "luzes" sobre os processos democráticos e suas contradições, sendo que uma dessas luzes será melhor abordada posteriormente.

Um segundo elemento compartilhado entre as posturas teóricas e conceituais expressadas e que, portanto, não deve ser excluído de qualquer noção sobre a democratização, é o grupo de fatores sociais resultantes das relações de poder entre os agentes governamentais e os cidadãos. Coincidindo com O'DONNELL e SCHMITTER (1991) e TILLY (2010), essas relações devem estar marcadas por aspectos como: a existência de um governo que tenha como princípio propiciar debates e consulta com a população; o respeito aos cidadãos na formulação de opiniões coletivas e aos resultados da deliberação entre eles; e a correspondência entre as demandas dos cidadãos e as ações do governo. 
Valorizando esse último aspecto, também é importante aprofundar no fato de que, sobre a base do compromisso que tem envolvido o conceito de democratização, ele deve ir além dos anteriores aspectos. Uma concepção sobre esse conceito/processo, que oriente uma análise empírica o mais objetiva possível, deve considerar como indicador essencial às transformações sociais que derivam do tipo de relações entre o governo e a sociedade civil. E, além disso, deve atender suas respectivas correspondências com os interesses, as necessidades e as expectativas da maior porcentagem da população possível. Isso evitaria assumir como processo real e consolidado de democratização aqueles debates e deliberações sem resultados concretos, que no fundo constituem estratégias maniqueístas de distribuição equitativa do poder.

Um seguinte aspecto, que inclusive deriva do anterior, tem haver precisamente com algumas das áreas onde deveriam ou poderiam se manifestar essas transformações. Quando se comentava acima sobre a ideia das transformações coerentes com os interesses e as necessidades dos cidadãos, elas não só estariam orientadas a questões associadas aos serviços públicos, mas também a transformações do "andaime estrutural", que sustenta as relações entre os cidadãos e os governos diante da configuração da política e da tomada de decisões.

Seguindo com algumas ideias de BOBBIO (1994) ${ }^{31}$, O’DONNELL e SCHMITTER (1991) ${ }^{32}$ e de WHITEHEAD (2002) ${ }^{33}$, estas outras áreas de manifestação das transformações consistiriam na materialização das vontades dos cidadãos nas formas democráticas de organizar e desenvolver os processos decisórios. Isso implica necessariamente que as normativas, os procedimentos, e/ou espaços para o debate e a tomada de decisões devam ser objeto de discussões e modificações em função de uma melhor estratégia de controle e julgamento das

\footnotetext{
${ }^{31}$ A democracia deve-se medir paulatinamente e a partir da conquista de novos espaços para a participação (BOBBIO, 1994).

${ }^{32}$ Processo onde também essas normas e procedimentos podem ser ampliados de maneira que incluam indivíduos (...) (O’DONNELL e SCHMITTER, 1991).

${ }^{33}$ (...) cabría esperar encontrar un debate público acerca de cómo va a constituirse la democracia y qué va a contar como un formato satisfactorio para construir un régimen democrático (WHITEHEAD, 2002, p. 51).
} 
práticas administrativas e, portanto, de distribuição do poder entre governantes e governados.

Um último aspecto a destacar sobre o assunto de que se trata tem uma conotação cuja importância não tem sido usualmente reconhecida nas teorias mais hegemônicas sobre a democracia. Essa conotação se localiza no âmbito subjetivo e se relaciona especificamente com as chamadas habilidades cognitivas. Segundo Whitehead, se,

“(...) consideramos a la "ciudadanía" como un ingrediente definidor de la democracia, entonces las habilidades cognitivas que son esenciales para el ejercicio de la ciudadanía constituyen en sí mismas un componente indispensable del concepto. Esto quiere decir que la democracia requiere o presupone la existencia de agentes autónomos, cada uno de los cuales forma sus propios juicios a la luz del análisis y el debate colectivos". (WHITEHEAD, 2002, p. 32).

Qualquer ferramenta teórica conceitual com a qual se pretenda analisar os processos democráticos deveria considerar o papel dos elementos cognitivos construídos pelos cidadãos em relação com esse processo. Mas essa consideração deve transcender de uma mera descrição linear e simples; a avaliação desse "mundo subjetivo" deve focar numa perspectiva relacional envolvendo pelo menos duas direções.

A primeira é a relação entre as subjetividades construídas e o funcionamento das estruturas (mecanismos, normativas, espaços) nos processos democráticos. A maneira como se produzem e reproduzem esses processos encontra um forte condicionamento nos conhecimentos dos cidadãos e suas formas de assumirem as estruturas existentes e seus papéis nesses processos. Mas, simultaneamente, esses componentes subjetivos são construídos historicamente (BOURDIEU, 1997), em correspondência com as próprias formas de funcionamento dessa estrutura, entre outros fatores.

Entretanto, a segunda relação admite que na construção social desses componentes subjetivos o Estado tem uma grande responsabilidade. As relações 
democráticas ou não que historicamente se têm desenvolvido entre os cidadãos e o governo, assim como os papéis e as estratégias assumidas por esses últimos para facilitar o necessário empoderamento da população nos processos decisórios, também repercutem nos graus de reflexibilidade crítica que os cidadãos possam adquirir.

O desenvolvimento da ideia anterior como componente da concepção da democratização contribui também para compreender certas formas de dominação e contradições dos processos democráticos que limitam o empoderamento dos cidadãos. Uma dessas formas é precisamente o papel ciente ou inconscientemente passivo do Estado na construção de cidadãos responsáveis e criticamente reflexivos. Uma população com essas características poderia constituir uma importante força política que exerceria pressão pela existência de um governo responsivo.

Segundo Whitehead, contudo,

\begin{abstract}
"Pero para que la democracia exista debe haber alguna comunidad disponible de ciudadanos reflexivos y responsables, y ésta no debe ser demasiado exclusiva. En otras palabras, los ciudadanos en general deben tener al menos cierto potencial para participar en la deliberación política con algún grado mínimo de competencia cognitiva, de vez en cuando, o al menos en el caso de emergencias verdaderas. Si cierto grado de competencia cognitiva generalizada es un prerrequisito mínimo esencial para la democracia política, entonces los aspectos esenciales deliberativos de esa competencia deberían estar incorporados dentro de cualquier descripción del significado del concepto de democracia”. (WHITEHEAD, 2002, p. 34).
\end{abstract}

Como bem pode ser visto, existe uma totalidade de diferentes aspectos teóricos e conceituais sobre os quais se poderia definir uma concepção sobre a democratização, capaz de orientar uma análise mais crítica sobre os processos democráticos. A natureza destes aspectos inclui desde características normativas e práticas até subjetivas e transformadoras. Por conseguinte, atendendo precisamente a essa totalidade de argumentos, pode-se propor assumir esse conceito como: processo de inter-relacionamento entre diferentes atores que, sustentado em certas práticas (símbolos, atitudes, estratégias) e formas organizativas (funções manifestas e latentes, mecanismos, cotas de poder), constituem formas de empoderamento dos 
cidadãos diante da configuração e reconfiguração da construção da realidade social e da política, em constante rearticulação dialética com os distintos contextos políticos onde se desenvolvam esses processos.

No entanto, com o objetivo de orientar uma análise viável em termos temporais e coerente com os fins acadêmicos e comparativos que aqui se perseguem, na presente pesquisa a democratização será entendida a partir de uma perspectiva mais simples, nos termos da ideia de "flotante pero anclada" que propõe WHITEHEAD (2002: 19). Nesse caso, tal conceito é definido então como: processo no qual os cidadãos e os atores políticos se inter-relacionam através de determinados procedimentos, garantindo a expansão das capacidades desses cidadãos para incidir na configuração das condições que sustentam a tomada de decisões sobre o público. É uma forma de exercer o governo onde os cidadãos controlam tanto os tradicionalmente detentores do poder político (atores políticos e governamentais), quanto suas decisões relativas aos assuntos públicos.

A partir da concepção anterior sobre a democratização e em diálogo com alguns componentes teóricos já citados, para os efeitos da atual pesquisa se derivam, por conseguinte, um conjunto de aspectos epistemológicos que resultam necessários destacar. Esses aspectos ressaltam os modos de produção de conhecimentos sobre o objeto de estudo desse trabalho, entre vários elementos. Nesse sentido se destaca, por um lado, a totalidade de atividades específicas e observáveis por meio das quais se poderia identificar a existência de processos de democratização ${ }^{34}$. Por outro, o conjunto de procedimentos metodológicos a serem utilizados, no processo de construção dos conhecimentos sobre o objeto em questão.

Um aspecto básico a ser considerado para identificar pelo menos uma tentativa de democratização é a existência de mecanismos que facilitem interrelações participativas entre cidadãos e governos no referente ao tratamento dos

\footnotetext{
${ }^{34}$ Essa proposta de atividades específicas e observáveis, em que se poderia identificar a existência de um processo de democratização, não pretende ser universal. Esse trabalho se considera apenas mais um aporte na produção acumulativa de conhecimentos sobre o processo mencionado. Portanto, a proposta em questão pode e deveria ser cumprimentada com outras abordagens.
} 
assuntos públicos. Para isso, poderia ser analisado o marco normativo desses mecanismos (funções outorgadas aos atores, objetivos, etc.), além das experiências de diferentes atores envolvidos nos mesmos.

Como nem sempre a existência desses mecanismos garante esse tipo de relações, é necessário não apenas identificar os mecanismos e suas bases normativas, mas também, o seu funcionamento em função de vários processos essenciais. Esses processos são: 1) a expansão das capacidades dos cidadãos para incidir nas condições que sustentariam essas relações e os processos de tomada de decisões, em particular; 2) o controle dos cidadãos e 3) o controle das decisões. Para analisar esses processos poderiam ser aplicados enfoques interpretativos da realidade que se estuda (conforme propõe Whitehead), por meio da utilização de métodos como a Observação e as Entrevistas.

Em relação ao processo 1, podem ser identificadas três atividades específicas. Uma delas é a maneira como os mecanismos orientados a sustentar as inter-relações entre cidadãos e governo contribuem para facilitar que os cidadãos influenciem as lógicas desses próprios mecanismos. Decorrente disso, se esperaria que os cidadãos pudessem transformar as existências dos procedimentos que guiam essas relações em função da tomada de decisões, mediante a proposição e materialização de mecanismos complementares e/ou alternativos.

A outra atividade é o papel que cumprem os mecanismos existentes nos processos de configuração normativa das relações entre cidadãos e o governo, no que atinge à tomada de decisões. $\mathrm{O}$ fato de que certos procedimentos oferecem capacidades para que a população possa discutir (refutar e/ou aceitar) aquelas normativas existentes (e/ou por existir) que regularizam os processos de tomada de decisões, implicaria um importante aspecto identificador de um processo de democratização.

Uma última atividade a considerar nos marcos do processo que se trata centra-se nos debates públicos e sua configuração. Esses debates constituem um 
passo fundamental diante de qualquer processo de democratização, porquanto se supõe que sustente as principais inquietantes, necessidades e aspirações da população, que deveriam sustentar as políticas e ações governamentais. Consequentemente, as agendas desses debates, assim como as formas que as definem, preferentemente deveriam ser configuradas pelos próprios cidadãos, segundos seus interesses, bem como deveriam ser supervisionados por essa população.

As três atividades mencionadas previamente, constituem alguns dos elementos essenciais (embora não os únicos) para identificar a existência de processos de democratização. As reais capacidades dos cidadãos para determinar a configuração das condições que sustentam os processos decisórios constituem um signo vital de empoderamento cidadão, como princípio da democratização. O caso contrário seria se essa configuração fosse responsabilidade exclusiva dos governos, o que implicaria, entre outros assuntos, melhores condições para decisões contraproducentes com os interesses públicos.

Em relação ao segundo processo, necessita-se analisar o controle dos atores políticos (Accountability, para certos autores), assim como nomear algumas atividades fundamentais que possam identificar empiricamente a democratização. A primeira dessas atividades está relacionada com a prestação de informações sobre a gestão dos atores políticos e suas justificativas. Num processo de democratização, os procedimentos estabelecidos deveriam facilitar que a população obtenha informações sobre a gestão dos atores políticos relacionadas com interesses concretos da população e, além disso, sobre as justificativas dessa gestão. Isso, supostamente levaria a um sentido de responsabilidade por parte dos governantes sobre suas decisões e ações específicas, que resulta imprescindível para o processo em questão.

Como derivação dessa atividade, se materializaria outra prática imprescindível num processo de democratização, que se pretenda analisar a partir do seu foco no empoderamento dos cidadãos. Essa prática é o exercício das capacidades 
desses cidadãos para avaliar a gestão dos atores políticos diante das demandas públicas. Além das informações necessárias que deveriam facilitar os mecanismos participativos ou democráticos, a avaliação que poderia fazer a população sobre a gestão governamental, também se converte como uma ferramenta de empoderamento dos cidadãos. Essas avaliações podem constituir formas de coação sobre os atores políticos, dependendo das configurações contextuais e históricas que tenham definido as relações entre esses últimos e a cidadania.

Por último, as capacidades dos cidadãos para exercer sanções sobre os atores políticos por causa das suas irresponsabilidades instituem mais uma atividade a ser considerada como reflexo de um processo de democratização. Na prática, resulta muito difícil constatar experiências de certas sanções da população sobre os atores políticos, em muitos países considerados de democráticos. As sanções que geralmente tem tido maiores capacidades para serem exercidas pelos cidadãos são de tipo políticas e consistem em destituições, cobranças e pressões sobre os mandatos dos governantes.

Essas sanções de tipo político também resultam válidas como indicador da democratização. Não entanto, elas também devem ser acompanhadas de atitudes de tolerância por parte dos governantes, de modo que não sejam motivo de discriminação ou perseguição política.

A última atividade a ser identificada se trata do controle das decisões sobre os assuntos públicos por parte dos cidadãos. Sobre a base desse processo, espera-se que a população tenha capacidades para incidir na definição das políticas públicas ou decisões vinculadas com os assuntos públicos em geral. Tal incidência será facilmente visível sempre que se analise a correspondência entre essas decisões tomadas pelo governo e as principais problemáticas colocadas pelos cidadãos, nos marcos daqueles mecanismos que sustentam as relações entre ambos. Ou seja, as capacidades em questão serão identificadas através do reflexo das demandas e necessidades da população nas políticas do Estado. 
Por outro lado, também se torna necessário que se visualizem as contribuições dos mecanismos existentes para impulsionar duas práticas fundamentalmente. Primeiramente, os cidadãos devem ser informados sobre as decisões relativas aos assuntos públicos antes de elas serem executadas e, além disso, deve haver possibilidades para discutir (aceitar e/ou refutar) tais decisões. Em segundo lugar, a execução das decisões tomadas nos territórios deve ser supervisionada pela própria população.

Esse conjunto de atividades descritas constitui para os efeitos da atual pesquisa os principais indicadores a serem utilizados para identificar processos de democratização surgidos a partir dos mecanismos que são objeto desse estudo: o OP em Porto Alegre, Brasil e as AMPP em Cárdenas, Cuba. É preciso, ainda, antes de continuar as próximas seções do atual informe de pesquisa, destacar mais alguns aspectos metodológicos.

Do ponto de vista empírico e metodológico, a ênfase em analisar os processos democráticos por meio da noção da democratização radica na sua vantagem para entender criticamente as formas de empoderamento que derivam das relações de poder entre o Estado e os cidadãos. Dessa forma, neste trabalho se prioriza analisar os resultados dessas relações como reflexo das capacidades dos cidadãos e não tanto as oportunidades (como bem foi expresso anteriormente), para incidir nas decisões.

De igual modo, é importante destacar que essa análise sobre os resultados também pretende ter uma particularidade. As reais cotas de distribuição de poder entre governos e governados estariam mais visíveis dependendo da importância que determinados resultados (assuntos públicos) adquiram para cada uma dessas frações da sociedade. E, junto a isso, as capacidades outorgadas aos cidadãos para influir nesses assuntos importantes em cada momento histórico.

A consideração do comportamento dessa relação entre o poder outorgado aos cidadãos - os assuntos públicos - o Estado e as decisões, lança uma "luz" 
necessária para não haver equívocos na admissão ou negação de existência de um processo de democratização em certas regiões, devido aos assuntos que os cidadãos possam influenciar. Pode ocorrer que as capacidades democratizadoras outorgadas aos indivíduos para atuar na distribuição política e administrativa (por citar apenas um exemplo), não tenham a mesma relevância nem implicância em termos de distribuição de poder para os cidadãos nem para o Estado em distintos lugares. Em qualquer análise sobre a democratização é preciso, pois, refletir sobre essa importância, já que ela define a existência ou não de relações democratizadoras. sobretudo quando se comparam experiências de regimes políticos diferentes, conforme se observa nos Capítulos seguintes. 


\section{OP e a AMPP em perspectiva comparada: capacidades para influir nas condições da tomada de decisões.}

No presente capítulo inicia-se a análise comparada sobre a execução do OP e das AMPP e seus aportes para a democratização das decisões sobre os assuntos públicos, nos seus respectivos territórios. Tal análise intenciona atingir o objetivo geral deste estudo: Comparar o funcionamento do "OP" em Porto Alegre e da "AMPP" em Cárdenas, sobre a base das suas atuais contribuições para a democratização das decisões sobre os assuntos públicos.

No desenvolvimento desta etapa se expõe como as ferramentas em questão contribuem para que a população influencie nas condições que sustentam a tomada de decisões. Esta ação está orientada a cumprir um dos objetivos específicos que levará ao cumprimento do desígnio geral proposto, segundo a estrutura lógica da atual pesquisa. Este objetivo é analisar as semelhanças e diferenças nas capacidades que com execução do OP em Porto Alegre e da AMPP em Cárdenas, exercem diversos atores locais para incidir na configuração das condições da tomada de decisões.

Para desenvolver o estudo correspondente à dimensão analítica que se apresenta no presente capítulo, são consideradas três subdimensões fundamentais, organizadas em forma de tópicos. A primeira subdimensão envolve o papel do OP e da AMPP no estabelecimento de procedimentos (alternativos ou não) que favoreçam o debate e a tomada de decisões sobre os assuntos públicos. A seguir, se examinam as mencionadas ferramentas em relação às suas capacidades para facilitar que a população incida no estabelecimento de normativas que sustentam os processos de tomada de decisões nos territórios de Porto Alegre e Cárdenas respectivamente. Por último, se analisam as capacidades de ambos os mecanismos para facilitar que a população acompanhe a definição da agenda dos debates públicos e influencie nos 
modos de definir essa agenda. Ao finalizar o capítulo, se mostra um breve resumo relativo às áreas onde as experiências resultam coincidentes.

\subsection{Estabelecimento de procedimentos para favorecer o debate público e a tomada de decisões}

Em referência ao primeiro aspecto a ser tratado para analisar as capacidades que a população adquire, mediante o OP, para influenciar nas condições da tomada de decisões, apreciaram-se diversas posturas entre os atores entrevistados em Porto Alegre. Entre funcionários com maiores vínculos governamentais, que são os Gestores dos CARs do OP e Vice-prefeitos, se reconhecem as capacidades do OP para influir no estabelecimento de procedimentos que favoreçam o debate público e a tomada de decisões. Nesse sentido, os citados atores colocaram várias questões importantes.

A primeira das questões é que, nos marcos do OP, não é uma realidade comum a discussão sobre o estabelecimento de mecanismos alternativos. Esse argumento é contrastado também com as experiências expressadas pelos Conselheiros do OP que colaboraram com a atual pesquisa, como no trecho destacado abaixo:

No marco do OP não tem se discutido o estabelecimento de outros mecanismos para o debate público, além do próprio OP (...). (...) não existe outra forma de consulta ou um mecanismo paralelo para fazer os debates públicos ou incidir na tomada de decisões. Outro mecanismo para ser criado não. Nunca ouvi falar algo parecido. Não. Eu tenho impressão que o OP é uma das maiores práticas de participação hoje, não só no Brasil, também no mundo inteiro. (...). Então isso faz com que o OP seja o principal espaço de debate público e a principal ferramenta de tomada de decisões em Porto Alegre ${ }^{35}$.

\footnotetext{
${ }^{35}$ Falas de Gestores dos CARs do OP, Vice-prefeitos e Conselheiros.
} 
No entanto, o que tem sido uma realidade comum entre a maioria dos atores é a criação de outros programas e mecanismos que, embora estejam mais voltados para a área dos serviços e para a procura de alternativas que impulsione o desenvolvimento (envolvendo múltiplos setores), têm favorecido a tomada de decisões e facilitado o aprimoramento do próprio OP. Isso tudo, reafirmando o OP como o principal espaço de debate público e a principal ferramenta de tomada de decisões em Porto Alegre.

Nesses termos, destacam-se mecanismos e/ou programas como: a ampliação do número de CARs, a criação dos Comitês Gestores do Território (CGT) (com a finalidade de planejar, articular e monitorar ações de governo para melhorar a qualidade de vida nos territórios: Educação, Saúde, Assistência Social, DEMAE, etc.) e o Programa "Prefeitura nas comunidades". Esses programas definem, junto com as comunidades, ações colaborativas nos territórios, focalizando diversas áreas: saúde, educação, limpeza urbana, iluminação pública, conservação e cuidado das praças, etc.

Além disso, os gestores entrevistados também resaltaram a existência de outros procedimentos ou espaços que funcionam como ferramentas de apoio ao $\mathrm{OP}$ e como forma de orientar a tomada de decisões. Tratam-se de procedimentos ou espaços que resultam da cooperação entre o próprio OP e o governo. Entre eles se destaca, por exemplo, o Fórum de Planejamento da Secretaria de Urbanismo ${ }^{36}$. Neste espaço, Conselheiros e Delegados se reúnem com a prefeitura para definir contrapartidas $^{37}$.

Junto ao citado Fórum, outros mecanismos mencionados pelos Gestores que funcionam dentro dos marcos do OP, com o mesmo propósito de aperfeiçoar os processos de debates e tomada de decisões, são as Plenárias anuais, as Assembleias,

\footnotetext{
${ }^{36}$ Esse Fórum, em termos de direção e administração, não depende do OP e foi uma criação do próprio governo. Mas os gestores acreditam que sua criação tem sido condicionada pelas relações entre o OP e a prefeitura, pelo importante papel que ele tem para promover a participação e a democracia no município.

${ }^{37} \mathrm{Ou}$ seja, se houvesse algum lançamento de um grande empreendimento na cidade, esse empreendimento deve oferecer alguma contrapartida para a própria cidade e, nesse espaço, se discute e se decide sobre essa contrapartida.
} 
os Fóruns Regionais do Orçamento Participativo (FROP), o Conselho do Orçamento Participativo $(\mathrm{COP})^{38}$, e as Audiências Públicas, solicitadas quando necessário. Tais mecanismos têm estado associados a discussões sobre importantes assuntos públicos, como o caso da licitação de transporte público, e da questão dos serviços nos bairros que ajudam a minimizar o uso indevido do poder público ${ }^{39}$.

Por último, tanto Gestores quanto Prefeitos reconhecem outro mecanismo na cidade de Porto Alegre, concebido como "braço auxiliar" e facilitador do OP (embora haja críticas por parte de alguns setores da sociedade). Trata-se da chamada "Governança solidária local (GSL)" ${ }^{40}$. O seu objetivo é trazer a iniciativa privada para trabalhar com a população e tentar estabelecer um diálogo entre o governo e a população, sempre mantendo a ideia do OP como principal ator na determinação de diferentes obras no município (esgotos, construções de escolas, creches, moradias, etc.) ${ }^{41}$.

Apesar dessas valorações sobre os procedimentos complementares que têm sido estabelecidos para favorecer os debates em Porto Alegre, alguns Gestores dos $C A R s$ reconhecem que, em certos momentos, a população tem proposto a criação de outros mecanismos alternativos. Essa disposição demonstra as capacidades do OP para promover discussões sobre a execução de procedimentos que possam enriquecer o debate público e aprimorar a tomada de decisões, mesmo que esses mecanismos alternativos não tenham sido materializados:

\footnotetext{
${ }^{38}$ Estas reuniões tem uma frequência quinzenal e as mudanças se decidem mediante votações.

${ }^{39}$ Os entrevistados afirmam que em épocas anteriores a prefeitura realizava obras nas regiões e bairros segundo seus interesses políticos, o que muitas vezes não estavam dentro das prioridades da população desses territórios e eram executadas com o objetivo de legitimar a gestão governamental frente aos processos eletivos. Situação que, de alguma forma, foi erradicada mediante o papel do OP, pois todas as decisões desse tipo devem ser discutidas e aprovadas nos marcos de relação entre o OP e a prefeitura.

${ }^{40}$ GSL é uma rede intersetorial e multidisciplinar que se organiza territorialmente para promover espaços de convivência capazes de potencializar a cultura da solidariedade e cooperação entre governo e sociedade local. Seu objetivo é estimular parcerias baseadas nos princípios da participação, autonomia, transversalidade e na corresponsabilidade em favor da inclusão social, aprofundando o comprometimento das estruturas de governo com as comunidades locais em ambiente de diálogo e pluralidade, e estabelecendo relações com a sociedade cada vez mais horizontalizadas (SECRETARIA MUNICIPAL DE COORDENAÇÃO POLÍTICA E GOVERNANÇA LOCAL, 2005).

${ }^{41}$ Apesar disso, segundo os gestores entrevistados, existem obras ou serviços que não necessariamente passam pela discussão com o OP: serviços emergenciais, serviços comuns, etc.
} 
(...) aqui na nossa comunidade a população às vezes tem pedido outros mecanismos. Mas, não se têm executado porque na verdade o OP participa com a prefeitura na gestão pública e, ao mesmo tempo, a prefeitura atua sobre a base do OP. Então não precisa outros mecanismos ${ }^{42}$.

Diferente do OP, no caso da AMPP em Cárdenas, apreciaram-se posturas similares entre a maioria dos atores entrevistados em relação às capacidades analisadas. Entre atores como Dc, Pcp e habitantes, destacaram como as principais ferramentas destinadas a materializar as relações democráticas ou participativas no interior da AMPP as Rc, as funções do Dc e as SeAMPP. Sem embargo, nas suas falas, esses procedimentos não foram reconhecidos como capacidades de influência no estabelecimento de procedimentos para favorecer o debate público e a tomada de decisões.

A primeira questão que sustenta a postura dos sujeitos mencionados é que nos marcos das Rc e das SeAMPP não é constante a discussão sobre o estabelecimento de mecanismos alternativos. $\mathrm{O}$ argumento que serve de base para esse fato é que os mecanismos para fortalecer os debates públicos e a tomada de decisões no âmbito da AMPP já estão estabelecidos pelo governo, sendo considerados os anteriormente citados como os mais eficientes, a partir do discurso oficial. Conforme depoimentos de atores como Dc, Pcp e habitantes entrevistados,

La creación del mecanismo de $\mathrm{RC}$ es buena, en el sentido de que a nivel de las asambleas tienes posibilidades de lograr la participación a todos los miembros de la circunscripción, no existiendo límites para expresar los criterios. Pero esos criterios están enfocados en nuestras problemáticas, no en la creación de otros mecanismos, a pesar de las limitaciones de esta herramienta participativa. De manera general no existen otros medios alternativos para favorecer la participación, pues ya existe y es el papel del Delegado. No existe un espacio para que en un momento determinado la población tenga la posibilidad de tomar decisiones sobre ciertos problemas que afectan las circunscripciones, inclusive como resultado de la propia gestión del gobierno. Está establecido constitucionalmente el mecanismo para la toma de decisiones, no existe otro.

\footnotetext{
${ }^{42}$ Falas dos Gestores dos CARs em Porto Alegre.
} 
As Rc, como espaço prévio e paralelo ${ }^{43}$ às Sessões (similar aos Fóruns Regionais em Porto Alegre), é onde se discutem as principais problemáticas das comunidades, inclusive até com a participação de funcionários do governo (ou prefeitura no caso do Brasil). Elas são realizadas em cada comunidade do município, com frequência estabelecida nas comunidades e dirigida pelos Delegados eleitos por essa população. Por outro lado, os Delegados são os representantes da população diante do governo e, portanto, um enlace entre as frações da sociedade. Como responsável pela execução das Rc, eles promovem os debates nas comunidades sobre os assuntos de interesses da população, e para isso se baseiam nas suas experiências em seus bairros e nos encontros diretos com as comunidades.

Sendo assim, os Dc consideram que a ideia de ter criado os mecanismos existentes é positiva, pois de alguma maneira ele deve fortalecer o debate e a tomada de decisões. Sobre as decisões, expressam que as realidades que são debatidas nesses espaços sobre as comunidades chegam até o governo com o propósito de servir como referentes para a gestão governamental. Entretanto, expressaram que, na prática, existem poucas respostas do governo sobre as problemáticas colocadas pela população. Isso se evidencia na repetição de demandas, conforme se mostra a seguir,

\begin{abstract}
Muchas veces las respuestas no satisfacen a la población o demoran en dar respuestas. Para lograr una real participación las personas tienen que tomar consciencia y comprobar que se les toma en cuenta y una de las formas en que se les tome en cuenta es que sean escuchados y que haya una devolución convincente ante las problemáticas que se discuten $^{44}$.
\end{abstract}

Nesses termos, portanto, os atores entrevistados não reconhecem algumas experiências onde tenham se debatido a necessidade de criar ou executar outros mecanismos alternativos ou não, conforme as seguintes palavras textuais: " $L a$ población nunca ha solicitado la creación de otros espacios". Sendo assim, as discussões sobre os assuntos públicos que podem interessar á população são

\footnotetext{
${ }^{43}$ Constitui um espaço prévio, porquanto que sua maior frequência determinada pelos Dc nas suas comunidades fazem com que muitas delas aconteçam antes das SeAMPP. E, em paralelo, pois constitui mais um espaço de debate nos territórios.

${ }^{44}$ Falas de Dc em Cárdenas.
} 
protagonizadas exclusivamente pelas SeAMPP, as Rc e pelo papel dos Dc, sem que nenhum desses debates tenha implicado a possibilidade de estabelecer outros mecanismos. Isso se dá mesmo existindo insatisfações em relação aos conteúdos dos debates que, nos marcos desses mecanismos, têm-se produzido em função dos interesses e das necessidades dos cidadãos.

Retornando para a experiência do OP, uma segunda semelhança ao caso da AMPP em Cárdenas consiste nos possíveis motivos que explicaram a ausência de debates sobre o estabelecimento de outros mecanismos. Nesse sentido, Gestores dos CARs e Vice-prefeitos em Porto Alegre consideram que essa ausência de discussão sobre mecanismos alternativos está associada ao papel que cumpre o OP como principal ferramenta democrática no município. Para esses atores, a maioria das decisões e obras a serem executadas nas comunidades ou bairros em Porto Alegre são objetos de discussão no OP, além das obras institucionais que são executadas em parceria com o governo federal. Para eles, pelo menos $80 \%$ das demandas em geral passam por dentro do OP, sendo que, como norma preestabelecida, a prefeitura realiza poucos serviços que não tenham passado pela instância.

Por outro lado, para certos Conselheiros que colaboraram com a atual pesquisa e que também reconheceram as capacidades mencionadas do OP, a ausência de debates sobre outros mecanismos tem motivos de diferente natureza. Nesses termos, eles afirmam que no marco do OP se discutem procedimentos para aprimorar o seu funcionamento no que tange ao fomento de uma maior participação popular nos assuntos públicos. No entanto, esses atores consideram desnecessárias as tentativas de criar outros mecanismos, principalmente por ser uma realidade que não é comumente vivida por eles. Os trechos de falas seguintes constatam esse argumento:

Eu não vejo necessidade de criar outro mecanismo e nunca ouvi falar dessa necessidade. Incluso no próprio COP se discute muito a ideia de fazer com que a coisas funcionem, mas dentro do OP. Não. Outro mecanismo para ser criado não. Nunca ouvi falar algo parecido. (...) acredito que o OP em sim, tem muito a melhorar e evoluir. E os debates tem estado orientados para isso. A gente sempre procura 
melhorar a qualidade do OP. E nesse sentido executamos mecanismos para fortalecer ele. Cada ano que passa o OP muda algumas coisas.

No entanto a esses argumentos, existe um pleno reconhecimento de que o instrumento em questão deve ser aprimorado paulatinamente, considerando seu papel central para os debates e a tomada de decisões. Especificamente, em âmbitos como: a transcendência de um debate meramente orçamentário (onde já se tem avançado consideravelmente); as relações entre o OP e a prefeitura na gestão dos assuntos públicos; e as possíveis estratégias para socializar o OP e facilitar uma maior incorporação da população (por exemplo, consultas mediante a internet). Ao redor desses assuntos, efetivamente se produzem debates nos marcos do OP, podendo-se assumir que o mesmo tem certas influências na definição das condições da tomada de decisões, mas não precisamente mediante a colocação de novos procedimentos:

Tem-se discutido mecanismos para ampliar os horizontes e as formas de atuação do OP, para que não esteja vinculado apenas a uma questão orçamentária. A gente tenta trazer mais pessoas para o $\mathrm{OP}$ e ao mesmo tempo se desenvolve uma análise sobre o OP, com o objetivo me melhorar ele. De repente o que sim poderia a gente imaginar é o aprimoramento paulatino dele. Eu acredito que o OP tem muito a melhorar e evoluir. E os debates têm estado orientados para isso ${ }^{45}$.

No caso de outros atores municipais que foram entrevistados em Porto Alegre e que têm uma maior ligação com a população (Delegados do OP, população em geral e alguns Conselheiros), os dados recolhidos oferecem informações que nem sempre reafirmam os argumentos dos discursos anteriores dos Gestores do CARs, Vice-prefeitos e certos Conselheiros. Alguns Delegados e habitantes assíduos ao OP apresentaram vários argumentos mais críticos em relação às capacidades que o resto dos atores reconheceu no OP, como mecanismo que propicia debates sobre o estabelecimento de procedimentos para favorecer o debate público e a toma de decisões.

\footnotetext{
${ }^{45}$ Falas de Vice-prefeitos, Gestores dos CARs, Conselheiros do OP.
} 
Nesse sentido, o primeiro argumento colocado por esses habitantes é que o OP tem servido para legitimar os partidos políticos (realidade reconhecida por outros atores: Gestores dos CARs, Conselheiros) e, além disso, constitui um mecanismo com amplo reconhecimento no nível internacional, questões pelas quais o governo pode não ter interesse em acabar com OP. O segundo aspecto é que o debate sobre a criação de outros mecanismos não tem sido uma realidade alheia ao município de Porto Alegre.

Consequentemente, segundo esses atores, se criaram mecanismos paralelos ao OP, como as Comissões regionais de Assistência Social (CORAS), a Voz de Usuários e o Comitê Popular da Copa. As CORAS tinham como propósito contribuir para o aprimoramento da assistência social no território. A Voz de Usuário pretendia ser um encontro entre todas as entidades, as comunidades, a prefeitura e as secretarias para debater as necessidades das comunidades, sobre a base de um debate mais espontâneo a partir das comunidades e sem mediações do OP. Por último, foi mencionado o Comitê Popular da Copa, criado por alguns moradores da região que inclusive participavam do $\mathrm{OP}$, mas que tentavam fazer coisas por fora do mesmo.

Sobre esse último mecanismo, um dos Delegados expressa que ele trazia um olhar diferente, porque seus integrantes não visualizavam no OP uma representatividade na luta ${ }^{46}$ para enfrentar situações criadas pela prefeitura e que violavam certos direitos. Um exemplo ilustrativo dessas problemáticas foi a condução das obras da Copa que, em muitos casos, implicou a demolição de moradias sem a construção de novos locais para essa população afetada. Tal cenário,

\footnotetext{
${ }^{46} \mathrm{Um}$ dos exemplos dessa pouca representatividade no OP por parte de certo setor da população foi ilustrada pelos habitantes e por um dos Delegados entrevistados, com o caso da Vila Hípica. Sobre isso, expressa um dos atores mencionados: "Eles foram os únicos que conseguiram moradias, mas não foi mediante o OP. Eles batalharam junto com o OP até um tempo. Depois decidiram sair do OP e fazer as coisas por fora dele. Por isso eles hoje não legitimam o OP. Eles sozinhos, mediante a sua liderança comunitária (Cândida) correram detrás de um vereador e conseguiram as suas moradias".
} 
segundo certos habitantes e Delegados, implicou a precarização da vida de muitas famílias, além da tensão social, do aumento da violência e da incerteza ${ }^{47}$.

Paralelo às vivências em Porto Alegre, relacionadas com os motivos que têm sustentado os debates (ausentes ou não) sobre outros mecanismos mediante ação do OP, em Cárdenas se visualiza uma realidade parcialmente similar. Para os atores entrevistados neste município, a ausência dessas discussões está associada ao papel que são chamados a cumprir as Rc, as SeAMPP e os Dc, como principais ferramentas democráticas.

O "dever ser" desses mecanismos construídos pelas regras oficiais e das formas históricas da consciência social nos processos participativos, na prática tem produzido um efeito adverso. Basicamente se tem minimizado as capacidades das Rc e da AMPP para democratizar as decisões e a configuração dos procedimentos que sustentam esses processos, contribuindo assim para que essas incapacidades sejam naturalizadas. Por isso, entre outros fatores, ocorre a omissão de debates para promover a criação de mecanismos que fortaleçam os debates públicos e a tomada de decisões, apesar das evidentes limitações existentes das Rc e SeAMPP como espaços democráticos.

Como reflexo dessas limitações, percebe-se que nenhum dos entrevistados apresentou exemplos concretos onde se tenha debatido a criação de procedimentos que favoreçam os processos citados, nos marcos das Rc e SeAMPP. Embora com suas particularidades, tais resultados têm algumas coincidências com falas de certos entrevistados em Porto Alegre.

O conjunto de aspectos antes mencionado deriva no reconhecimento da necessidade de melhorar os mecanismos em questão, como instrumentos centrais para os debates e a tomada de decisões, principalmente em âmbitos como a erradicação de debates sem posteriores efeitos práticos na gestão governamental e o papel desses instrumentos numa maior democratização da gestão dos assuntos

\footnotetext{
${ }^{47}$ Alguns dos lugares mais críticos que nesses termos foram identificados são as Vilas: Cristal, Tronco Neves, Divisa e Cruzeiro.
} 
públicos. Ao redor desses assuntos, evidencia-se a falta de produção de debates nos marcos das Rc e SeAMPP, podendo-se assumir que as mesmas têm limitações para influir na definição das condições da tomada de decisões, sobre tudo mediante a colocação de novos procedimentos e do aperfeiçoamento dos mecanismos existentes. Como exemplo desses argumentos, pode se considerar essa ausência de relatos narrados pelos entrevistados sobre experiências de debates e/ou execução de novos mecanismos alternativos ou não.

Uma segunda subdimensão a ser tratada como base analítica para examinar as capacidades do OP e da AMPP para facilitar que a população influencie nas condições da tomada de decisões está relacionada às regras que fundamentam os processos decisórios. Nesse sentido, se faz necessário analisar as contribuições que essas ferramentas fazem para impulsionar discussões onde a população possa aceitar ou refutar regras a serem estabelecidas para a tomada de decisões.

\subsection{As normativas que sustentam os processos decisórios sobre os assuntos públicos.}

Em relação às normativas dos processos decisórios dos assuntos públicos, constatou-se que, em geral, os entrevistados em Porto Alegre deram uma opinião favorável, se baseando no papel que cumprem o RI o COP nesse processo de discussão. Sobre o RI, tanto os Gestores dos CARs quanto os Conselheiros do OP e alguns membros da prefeitura expressaram que este constitui a principal contribuição que faz o OP para a discussão e a criação de regras que sustentem a tomada de decisões. Ele é discutido e modificado todos os anos, em função dos constantes debates entre a prefeitura e as comunidades em distintos espaços (FROP, COP). Essas mudanças, na maioria das vezes, estão orientadas a normativas vinculadas com a condução das temáticas ou com o funcionamento do próprio OP como um "todo" regional. Portanto, nos marcos do mencionado mecanismo, são definidas diretrizes de organização do $\mathrm{OP}$ e do próprio governo em relação às decisões através desse RI. 
O COP, por sua vez, constitui o principal espaço que facilita o OP cumprir a missão de democratizar as decisões sobre os assuntos públicos, analisando e debatendo anualmente as normativas que regem e regerão a forma como se tomam as decisões no município. A partir dos acordos tomados no COP (onde participam todos os conselheiros do OP, além de um membro da prefeitura que atende este mecanismo), se elabora o RI que regula todo o funcionamento do OP e sua relação com o governo.

Por conseguinte, considerando as falas de alguns entrevistados, pode-se observar que, basicamente, as regras que determinam a forma como se tomam as decisões são estabelecidas a partir de uma parceria entre o governo e o OP nos marcos do COP, na qual, mediante votação, são aprovadas ou refutadas as possíveis alterações normativas. Sobre isso alguns Gestores dos CARs e Conselheiros do OP expressam que

(...) em relação com a definição das normativas que determinam a forma em que são tomadas as decisões, é importante dizer que anualmente esses assuntos são discutidos no COP, e as decisões tomadas coletivamente são colocadas no RI do OP. Neste RI são expressas normativas de funcionamento relativas ao governo quanto à população, ao OP etc. Nós temos um RI com regras relativas à população e ao governo. E entre as coisas estabelecidas nele está a forma de tomar as decisões. As regras para a tomada de decisões são resultado de um acordo entre o governo e o OP. Esse RI é analisado, debatido e alterado anualmente e as mudanças são aprovadas no COP. O OP contribui para o estabelecimento e a discussão de regras para a tomada de decisões. O próprio RI cumpre com essa função. Isso faz com que qualquer decisão que seja tomada no município passe pelo OP. E essa decisão ou acordo entre o governo e a população é executada sobre a base de regras nas quais o OP tem incidido. Regras que estão presentes no RI. Basicamente as regras que determinam a tomada de decisões são estabelecidas a partir de uma pareceria ente o governo e o OP, como representante do povo.

Do que tange às experiências em Cárdenas sobre a dimensão que se analisa, se percebe que, em geral, os entrevistados não deram uma opinião favorável. Essa opinião se baseia no papel que, na prática, cumprem os Dc, as Rc e as SeAMPP nesse suposto processo de discussão. 
Como foi declarado anteriormente, os Dc promovem debates sobre as principais inquietudes da população nas suas comunidades. Para isso, utilizam espaços como as próprias Rc, além dos despachos ${ }^{48}$ estabelecidos uma vez por semana.

Nessas Rc, os Dc oferecem para a população as respostas que foram dadas pelo governo sobre as demandas e problemáticas colocadas nas reuniões anteriores. Além disso, esse ator também terá o dever de responder aos questionamentos pertinentes feitos pela população, no caso de conhecer as situações concretas colocadas no debate. As problemáticas colocadas nesses espaços fundamentalmente estão associadas aos serviços, particularmente a questões como eletricidade, saneamento, iluminação, entre outros. Posteriormente, nas SeAMPP se produzem debates similares, segundo a ordem do dia.

Assim sendo, esses espaços não são reconhecidos entre os atores entrevistados como mecanismos que contribuem para estabelecer debates, aceitar ou refutar normativas para definir a tomada de decisões. Isso implica, portanto, que as regras que sustentam os processos de tomada de decisões usualmente não são objeto de debates entre a sociedade civil e o governo nos marcos das Rc e SeAMPP. De tal modo, se revelam as limitações desse mecanismo para democratizar as decisões sobre os assuntos públicos, a partir da sua incidência na definição das regras que estruturam os processos decisórios. Basicamente, o estabelecimento dessas regras é competência do governo central, e não necessariamente sobre a base de um compartilhamento do poder com a sociedade civil, pelo menos no nível prático. Sobre isso, se expressam alguns atores entrevistados:

En las asambleas a nivel de circunscripciones no se han planteado normativas para regular la toma de decisiones. Es el gobierno quien toma las decisiones y así está establecido. Las reglas para tomar las decisiones ya están establecidas desde el nivel central. A veces, ni siquiera los gobiernos municipales pueden cambiarlas, así que las SeAMPP menos todavía podrían cambiarlas ${ }^{49}$.

\footnotetext{
${ }^{48}$ Reunião de coordenação e intercâmbio entre as partes.

${ }^{49}$ Falas de Dc, habitantes, Pcp em Cárdenas.
} 
Retomando a análise sobre a maneira como o OP favorece a discussão de normativas para regularizar a tomada de decisões sobre os assuntos públicos, vários atores apresentaram exemplos que constatam essas capacidades. Um deles é o tempo para a conformação das chapas dos Conselheiros para suas eleições. Antigamente, para homologar essas chapas tinham que ser apresentadas as propostas com 48 dias antes. Atualmente são sete (7) dias.

Outro aspecto ilustrativo são as discussões que tiveram lugar para aprovar que, a partir de dezembro, todos os planejamentos das Secretarias passem pelos FROP. Esse fato contribui para evitar que as Secretarias façam ações ou empreendimentos distintos daqueles demandados pela comunidade. Essa determinação é um fator importante que mostra as capacidades do OP para incidir na configuração de normativas para a tomada de decisões ${ }^{50}$.

De igual modo, outro exemplo colocado por esses atores foi a aprovação das Leis Orçamentária Anual (LOA) e de Diretrizes Orçamentária (LDO), que funcionava de modo distinto. Hoje a LDO é encaminhada para a câmara de vereadores, onde são feitas as votações, retornando para o OP para ser discutida novamente. Há outras regras relacionadas à tomada de decisões que passam pelo OP, como a aprovação da discussão pelo OP tanto das grandes obras demandadas pelas comunidades como dos serviços oferecidos pelas secretarias do governo:

\footnotetext{
${ }^{50}$ Em relação às capacidades do OP para a discussão de regras a serem estabelecidas, um dos Conselheiros expressou não concordar com a ideia de que o OP tenha, num momento determinado, poder para legislar Lei e/ou normativas: "Eu não vejo como positivo que o OP deva discutir ou estabelecer normativas ou leis. Para isso a gente tem a Câmara de Vereadores. Se nos começáramos a fazer com que o OP possa legislar ou interferir na legislação, acho que não seria positivo. Propostas para esse processo já são feitas. O próprio o OP não está legislado. Ele é um pacto social, uma ferramenta e forma de governo para dialogar e proporcionar um maior debate entre as comunidades. Não existe uma lei que determine a existência do OP. Existe na verdade uma orientação do governo para que o OP possa existir e também se pede que o OP de a sua opinião. Então, eu não vejo com bons olhos o OP como legislação ou como ferramenta que legisla, porque ai se desconsideraria totalmente a Democracia representativa, que de fato é importante para a nossa cidade. As pessoas que estão lá foram eleitas pela cidade. Agora nos sim precisamos uma maior qualificação da Câmara dos Vereadores. Mas essa qualificação deve se dar pela participação das pessoas, lá nas campanhas eleitorais, escolhendo bons candidatos que estejam capacitados para o cargo".
} 
Por exemplo, a gente conseguiu aprovar que não só as grandes obras demandadas pelas comunidades passem pelo OP. Mas também os serviços oferecidos pelas secretarias do governo tem que passar pelo OP. Ou seja: destelhou o telhado numa escola e tem que votar um telhado novo? Antigamente as secretarias iam lá, prestavam esse serviço e pronto. Hoje não, hoje elas têm que passar pelos FROP e os delegados para ser aprovado. Também para acontecer uma obra institucional (obra de saúde da secretaria da saúde, por exemplo), tem que passar pela região dentro do FROP e ser aprovada lá. Estas mudanças foram feitas desde há um mês mais ou menos. Porque antigamente as secretarias faziam essas obras sem contar com a população, e a gente descobriu que existiam politicagem e favoritismo nas obras. Porque as secretarias faziam obras onde tivessem interesses políticos. E isso desmotiva e desmobiliza as pessoas ${ }^{51}$.

A influência desse mecanismo na determinação de normas latentes relacionadas com a tomada de decisões é um aspecto importante a ser observado. Para demonstrar esse fato, a maioria dos gestores colocaram outros exemplos onde a prefeitura tem contemplado o OP para tomar decisões sobre assuntos importantes. Os casos mais emblemáticos foram a Licitação do Transporte Público e o Viaduto da Igreja São Jorge, que anteriormente não visavam a passagem de dinheiro ${ }^{52}$.

Levando em consideração os exemplos apresentados que demonstram a relação entre a prefeitura e o OP na tomada de decisões no município, os atores mencionados até aqui consideram positivamente as capacidades de incidência do OP na definição das regras para a tomada de decisões. Eles afirmam que o fato do OP ser um pacto entre o governo a população, onde está determinado que as ações do governo devam ser discutidas com a população, significa um passo de avanço na democratização das decisões (pelo menos em relação com o aspecto em questão).

No referente à exemplificação das capacidades que se examinam, se constatou que entre os entrevistados em Cárdenas não se reconhece uma clara parceria entre o governo e a sociedade civil, de modo que, mediante mecanismos

\footnotetext{
${ }^{51}$ Falas de Gestores dos CARs e Conselheiros.

${ }^{52}$ No entanto, devem-se destacar as críticas que alguns moradores fizeram nesse sentido, por causa das limitações e da posição passiva frente às tentativas de mudar decisões que, sobre a base de normas federais, visavam prejudicar um conjunto de pessoas para favorecer certos setores econômicos. Esse foi o caso das tentativas de Remoção no Morro Santa Teresa.
} 
como as Rc e as SeAMPP, possa-se influir na definição das normativas que sustentam os processos de tomada de decisões. Como resultado dessa realidade, conheceram-se algumas experiências de decisões que sendo tomadas no território, têm afetado a população sem esta apresentar capacidades para mudar as normativas que sustentam esses processos decisórios.

As experiências colocadas para ilustrar essas limitações foram várias e, fundamentalmente, estão relacionadas à localidade de Varadero ${ }^{53}$. Entre os exemplos colocados se destacam a estratégia executada há alguns anos para combater as ilegalidades relacionadas com as moradias no município e as leis que proíbem a divisão de propriedades privadas em Varadero, neste caso, as moradias.

Sobre a estratégia de combate às ilegalidades, sua execução consistiu em demolir as construções ou ampliações construtivas feitas pelos cidadãos de Varadero, inclusive dentro dos limites das suas propriedades. $\mathrm{O}$ argumento da ação sustentou-se no argumento de que eram proibidas pela lei a construção e a ampliação das moradias nessa região, mesmo estando nos marcos das propriedades privadas ${ }^{54}$. Considerando as falas dos entrevistados, essa foi uma decisão tomada somente nos marcos governamentais, sobre a base de normativas que têm sido configuradas sem o necessário debate com a população que posteriormente se veria afetada ${ }^{55}$.

A insatisfação da população em relação às leis que proíbem a divisão das propriedades de moradia em Varadero é evidente. Nenhum dos cidadãos entrevistados conhece a maneira como essas normativas foram aprovadas, tampouco

\footnotetext{
${ }^{53}$ Varadero é um território (península) pertencente atualmente ao município de Cárdenas, localizado no norte da província de Matanzas, a $130 \mathrm{~km}$ no este da capital de Cuba, "La Habana". No ano 2010, a ANPP decidiu reestruturar a divisão político-administrativa do país, fazendo perder esse território sua condição como município.

${ }^{54}$ Apesar da proibição pela Lei, houve cidadãos que foram autorizados pela "Dirección Municipal de Vivienda" (Direção municipal de Moradia) para fazer suas construções nas suas propriedades, diante do normal crescimento do núcleo familiar. Mesmo com o consentimento da mencionada entidade estatal, as construções forma demolidas trazendo incômodos e preocupações para população.

${ }^{55}$ Neste caso, as ANPP constituem o espaço democrático com poder legislativo onde participam os Delegados eleitos pelos cidadãos, de onde poderia ter saído a definição dessas regras, nos marcos de um sistema político Socialista e centralizado que define o Estado como poder do povo (ANPP, 2010). No entanto, nenhum dos entrevistados comentou ter tido conhecimentos sobre a existência de algum debate público sobre essas decisões nem sobre as bases normativas para sustentá-las diretamente.
} 
tem conhecimentos claros sobre as particularidades das mesmas, porquanto elas não têm sido previamente debatidas nos espaços democráticos estabelecidos no nível municipal. Só conhecem que essas proibições foram estabelecidas nos estratos superiores do Estado e que se sustentam no caráter estratégico que, para a economia nacional, tem o território de Varadero, junto com outras localidades no seu redor.

Como resultado dessas normativas, tem-se produzido no âmbito social realidades complexas, que inclusive se contradizem com alguns princípios históricos da Revolução cubana: igualdade, justiça, ao tempo que violam o direito de propriedade reconhecido universalmente. Existem hoje em Varadero moradias onde habitam mais de três gerações, sem oportunidades não só de ampliar suas construções, senão também de dividir suas propriedades entres os moradores.

Apesar destas propriedades não poderem ser divididas, as moradias em sentido físico podem. Mas isso implica um necessário entendimento entre as partes que a maioria das vezes não se aplica. Quando é aplicada, em muitas ocasiões, não responde ao que poderia ser feito em termos legais e justos, porquanto a "lei do mais forte" tem maior liberdade para se impor. Essa situação sugere, portanto, assumir certa ausência do Estado para cumprir com suas funções de fazer valer a justiça.

Outro aspecto necessário para ser tratado é a relação de convivência desse mecanismo com algumas normativas tácitas relacionadas com a tomada de decisões. Mediante as falas dos entrevistados, além de se perceber que as SeAMPP não facilitam a discussão, refutação e ou aceitação de normativas para regularizar os processos decisórios, também se constatou que elas não conseguem desmontar normativas implícitas associadas a esses processos. Entre alguns Dc, habitantes e Pcp., se reconhece que como pauta geral o governo se assume como máximo e único responsável pela tomada de decisões, sendo essas decisões difíceis de questionar ou contradizer. Para eles, questionar certas decisões pode levar à construção de imagem negativa do ponto de vista político e social, que conduziria à discriminação de suas possíveis contribuições como atores locais: 
En ocasiones el consejo de la administración toma decisiones y no se le informa al delegado, por tanto no llega a los electores. (...) Las instalaciones de carácter histórico del municipio de cárdenas están destruidas totalmente y no se proyectan decisiones para su restauración; en tal tema el pueblo pudiera participar; sin embargo los órganos decisores son a nivel de gobierno en provincia. El gobierno es quien toma las decisiones. No quisiera tener problemas a raíz de lo que he expresado. Me gustaría que no dijeras mi nombre para así no herir a nadie y evitar desavenencias. Desearía que esta conversación fuese anónima para evitar que mis críticas sean malinterpretadas y ser cuestionado por los dirigentes.

De maneira geral, os argumentos relatados sobre as experiências das AMPP em Cárdenas constituem não só exemplos de incapacidade para incidir na configuração das regras que sustentam os processos de decisórios sobre os assuntos públicos, como também ilustram a autonomia do governo central para estabelecer normativas sobre os espaços municipais, diante das quais os governos locais e a população se encontram limitados para agir em defesa de certos interesses dos cidadãos.

Mas, paralelamente aos aspectos favoráveis descritos em Porto Alegre e desfavoráveis expostos em Cárdenas, alguns outros entrevistados também admitiram limitações relacionadas ao OP e às capacidades em questão. Essas limitações, assumidas nas posturas mais críticas de alguns sujeitos entrevistados na capital gaúcha, podem ser consideradas um ponto de contato com a experiência cubana que se analisa.

De forma colateral às capacidades reconhecidas para que a população portoalegrense incida nas normativas que definem os processos decisórios, também se admite que elas podem ser afetadas em algum momento. Isso decorre da sua dependência do gestor público que preside o governo municipal, e também em virtude de um possível aumento do número de ações governamentais sem passar pelo $\mathrm{OP}^{56}$.

\footnotetext{
${ }^{56}$ A maioria dos gestores reconhece que na prática nem sempre são discutidas todas as ações e decisões nos marcos do COP, sobretudo quando se trata de questões mais gerais do município. Embora tenham existido ações que mesmo nesse âmbito tenham passado pelo OP.
} 
No entanto, entre habitantes da população e alguns Delegados do OP, as limitações reconhecidas do OP adquirem um caráter mais crítico. Para esses sujeitos, o OP atualmente está distante de poder incidir significativamente na definição de regras para a tomada de decisões. Por um lado, isso está condicionado pelo tipo de população que acostuma participar do OP. O fato de ter uma classe média ausente desse tipo de debates limita o OP de contribuir para esses propósitos. Por outro, a condição de Porto Alegre como município também limita esses assuntos, sobretudo no que tem haver com decisões que afetam o território e que não podem ser mudadas porque apresentam uma dependência Federal.

De igual forma, esses entrevistados expressaram sua relativa desconfiança nesse processo de definição de regras, argumentando que, além de existir descumprimentos com algumas normativas pautadas ${ }^{57}$, existe certa manipulação em função de interesses pessoais e/ou políticos para definir algumas regras. Tais questões coincidem com as expressões de um dos habitantes entrevistados, para quem os debates sobre esse tema são produzidos, mas com poucas implicações no ponto de vista prático. Sobre esses assuntos, versam as seguintes citações:

\begin{abstract}
Eu vejo o OP muito distante de poder influir na tomada de decisões para definir as regras sobre as quais serão tomadas as decisões. E isso tem uma relação direita com a condição do município. Não há mais um processo coletivo nesse sentido. Por exemplo, a classe média não participa hoje do OP. E ela era quem levava muito mais um processo crítico dentro do OP. Era uma classe média progressista, mais interessada na construção do poder público, do controle social. No OP existem regras que regulam o processo de tomadas de decisões. Essas regras são o RI e ele é transformado todos os anos. Então todos os anos tem esses debates. Às vezes essas regras que eles mudam até melhoram ou pioram as coisas. Porque já tem interesses ai, uns manipulam a outros e por ai vai. A questão dos mandatos dos conselheiros é uma dessas manipulações, que é favorecida pela pouca motivação que têm as pessoas por ocupar cargos como esses. Eles fazem esses debates para regularizar o processo de tomada de decisões. Mas isso não tem futuro, fica ai nesse momento e pronto. Agora no marco regulatório tem algumas coisas que vão ter que ser mudadas. Você pode até debater, mas daí não vai sair ${ }^{58}$.
\end{abstract}

\footnotetext{
${ }^{57}$ Neste caso o descumprimento consiste em que, segundo um dos habitantes, no próprio RI diz que as obras aprovadas devem ser efetuadas até o próximo ano e, se não o forem, deve-se justificar por escrito. Isso não acontece, sendo que, muitas vezes, o governo nem informa sobre esse assunto.

${ }^{58}$ Falas de habitantes, Delegados e alguns Conselheiros, que também coincidem com algumas falas dos especialistas entrevistados, no referente às limitações do OP para influir significativamente na definição de normativas para a tomada de decisões, apesar da existência do RI e sua natureza.
} 
Um último aspecto a considerar nesse capítulo, a fim de analisar as capacidades do OP e da AMPP para facilitar que a população influa nas condições da tomada de decisões, é a agenda dos debates públicos, particularmente, com a maneira como essas ferramentas facilitam a influência da população nos modos de definir a agenda dos debates públicos e, além disso, supervisionar a definição dessa agenda.

\subsection{A agenda dos debates públicos, seus modos de definição e supervisão.}

A realidade deste tema em Porto Alegre é favoravelmente valorizada quando se leva em consideração as falas da maioria dos entrevistados. Segundo eles, a agenda dos debates públicos se estabelece dentro do conhecido ciclo do OP, que começa pelas preparatórias para as PR e, por conseguinte, pelos FROP.

Em cada região são realizadas as chamadas PR, nas quais se estabelecem as quatro prioridades dessa região que receberão financiamento e o conjunto de demandas focadas nessas prioridades. Do mesmo modo são eleitos pela população os Conselheiros (4) e os Delegados ${ }^{59}$ de cada região. Assim, a agenda dos debates se configura nos marcos das PR e suas preparatórias e, nelas, se estabelecem os aspectos mencionados para posteriormente continuar os debates nos marcos dos FROP.

Cada região de Porto Alegre tem seus FROP, que são realizados com certa frequência (varia dependendo da região: 15 dias, um mês, etc.), reunindo lideranças, conselheiros, delegados eleitos de cada região e demais pessoas que quiserem participar. Objetiva-se, dessa forma, discutir diferentes problemáticas das comunidades junto aos secretários da prefeitura, quando necessário.

\footnotetext{
59 A quantidade de delegados depende da quantidade de pessoas que assistam às PR. Por cada dez participantes vinculados a uma comunidade, se tira um delegado que seria uma representação popular frente ao FROP.
} 
Em virtude dos FROP ter como prerrogativa inicial verificar o andamento das obras do OP e discutir sobre os interesses da população, a realização de certos debates é facilitada. Esses debates se estabelecem sobre a base de uma agenda configurada a partir das demandas feitas pela população nas PR, ou a partir do diálogo entre o povo e seus Delegados eleitos. Portanto, nas sessões dos FROP são estabelecidas pautas que facilitam os debates e guiam o cumprimento dos acordos, que depois são informados à população. Esse é um dos passos fundamentais na definição da agenda dos debates públicos, onde o OP é o principal gestor.

Nesses espaços o poder público é cobrado sobre os mais variados assuntos. Por exemplo, se houver problemas com a execução de uma obra de esgoto, ou se os conselheiros locais quiserem discutir o saneamento básico, convoca-se o DEMAE ou o Secretario do departamento da prefeitura responsável por esses assuntos, a fim de discutir, entre outras questões, os motivos do descumprimento com os acordos e as alternativas a serem executadas para solucionar esses problemas.

Posteriormente, essas temáticas discutidas são levadas para o COP, que reúne os Conselheiros do OP responsáveis por diferentes temáticas: cultura, transporte público, etc. Aqui também participam Gestores do OP, Delegados e atores da prefeitura (sem voto e com voz somente se for autorizada pelos conselheiros), além de qualquer pessoa que quiser participar, por ser uma reunião aberta ao público. Os Conselheiros do OP têm o dever de, sobre a base de suas relações com os Delegados e a população em geral, definir os temas a serem discutidos com as Secretarias da prefeitura. Para isso podem até convocar para as sessões do COP os secretários, o prefeito, os vice-prefeitos e outros funcionários que atendam aos temas de interesse.

De outro lado, os CARs também cumprem um papel importante no processo de definição de debates sobre as problemáticas da população e de definição de estratégias. Nos FROP, são avaliadas pelos Conselheiros, lideranças e demais pessoas presentes as demandas da população (de creches, obras, postos de saúde, etc.), para serem transmitidas para o governo ou para as Secretarias especificas (de governança, de saúde, de educação, etc.), por mediação dos CARs. A partir desse 
processo, os CARs devolvem as respostas para a população, sobre tudo mediante os Conselheiros e líderes comunitários, tentando assim articular essas demandas com a gestão do governo.

No consenso geral, as capacidades do OP para incidir nos modos de definir a agenda dos debates públicos ficam demonstradas no fato de que toda essa forma de materializar e conduzir os debates resultam dos acordos estabelecidos mediante o diálogo e a colaboração entre o governo e a população que participa junto ao OP. Esses acordos, segundo os gestores dos CARs entrevistados, são incluídos anualmente no RI, onde aparecem regras relacionadas à população e ao próprio governo $^{60}$.

Sobre as capacidades anteriores, alguns Conselheiros do OP, juntamente com os Gestores dos CARs, concordaram em reconhecer que esse mecanismo contribui para que a população influencie as formas de definir a agenda de debates. Desse modo, confirmou-se que o processo de debate público mencionado é resultado da evolução do OP, como proposta do próprio OP e da população, para aprimorar esse mecanismo. Por conseguinte, reafirma-se que a maneira como hoje se desenvolvem esses debates tem sido definida pelo próprio OP junto às comunidades, permitindo assim inferir que a população tem capacidades para incidir diretamente nas normativas que regulam a definição da agenda dos debates públicos.

Igualmente, as declarações dos habitantes e dos Delegados entrevistados resultam coincidentes com os argumentos anteriores. Desse modo, constitui esse aspecto da democratização um dos principais pontos onde se percebe uma unanimidade de critérios entre os diferentes atores entrevistados (Gestores dos CARs, Conselheiros, Delegados, Habitantes e Vice-Prefeitos):

Apesar das dificuldades de todo esse processo, o OP incide na definição da agenda pública, porque essa agenda é feita precisamente nos marcos do OP. E essa forma de definir a agenda tem sido decidida também nos marcos do $\mathrm{OP}$. Ou seja, é a própria população representada pelos delegados e conselheiros os que têm decidido esta

\footnotetext{
${ }^{60}$ Fundamentalmente, Título I (Capítulos I, II, III e IV) e Titulo II (Capítulos I, II, III, IV e V).
} 
forma de definir a agenda de debates públicos. Esse processo organizativo que falei antes permite acompanhar precisamente a definição da agenda. Porque essa agenda é feita pela própria população e desenvolvida pelos representantes que a população escolheu (...). E a partir destas figuras a população vai acompanhando os debates que estão sendo feitos em cada espaço de debates.

Por outro lado, as conversas dos atores entrevistados sobre as experiências em Cárdenas acerca das capacidades da população para influenciar os modos de definir a agenda dos debates públicos e para supervisionar tal definição não mostraram uma realidade satisfatória. Entre outros aspectos, foi notável a necessidade de garantir a articulação de debates que nascem espontaneamente da população.

Os debates públicos em Cárdenas se realizam mediante dois espaços fundamentais interligados entre si. Um deles são as próprias SeAMPP e o outro são as Rc dos Delegados aos seus eleitores.

A agenda de debates das SeAMPP é definida pelo próprio governo a partir dos seus interesses e enviada para os Dc com não menos de 10 dias, com a finalidade de avaliar e discutir com a população a inclusão de outros temas. Posteriormente, o Presidente da AMPP recebe as propostas e confecciona a agenda de debates, que será aprovada no início da Sessão. Nessa agenda, também podem ser incluídos os acordos que foram tomados nas Sessões anteriores:

El proyecto de Orden del Día de las sesiones ordinarias de la AMPP es elaborado por el presidente, según la situación concreta que dé lugar a la convocatoria, quien lo somete a la aprobación de la Asamblea. El Orden del Día puede incluir asuntos como los siguientes: a) el estado de cumplimiento de los acuerdos y disposiciones adoptados por la Asamblea Municipal en sesiones anteriores, $(\ldots)$; b) las decisiones de carácter general adoptadas por el presidente que deban ser consideradas por la Asamblea, (...); d) los temas que con antelación hayan presentado los delegados al presidente (...); f) los relacionados con aspectos económicos, sociales y otros que por su importancia, trascendencia y actualidad deban ser examinados por la Asamblea (...) (AMPP, 1995, art. 37). 
Essa forma de definir a agenda de debates no município de Cárdenas é o resultado de tentativas governamentais para aprimorar os processos participativos em nível municipal, conforme consta no conjunto de modificações ocorridas paulatinamente a partir da conformação dos governos municipais em $1976^{61}$. Não obstante, os cidadãos não se incluem subjetivamente como participantes do processo decisório que deu lugar à existência das atuais maneiras de definir a agenda dos debates no território. Inclusive, as próprias SeAMPP e Rc não têm promovido debates sobre o estabelecimento e/ou aprimoramento dos modos de definição dessa agenda:

No recuerdo ningún momento en el que las SeAMPP se haya discutido algo sobre cómo definir el orden del día. La forma en que eso se hace ya está definido en los reglamentos. La forma en que se establece el orden del día de las SeAMPP ya está definida por el gobierno y las leyes correspondientes. Nosotros como población no hemos discutido sobre eso. No recuerdo momento así en el que las Rc y SeAMPP se haya dado un debate sobre cómo definir el orden del día, ni se haya llevado propuestas para aprobar o renovar la forma en que hoy se hace eso.

A limitações também são visíveis sobre a questão das capacidades do mecanismo que se analisa para facilitar que a população supervisione a definição da agenda dos debates públicos. Nenhum dos atores entrevistados expressou ter conhecimentos sobre as temáticas que o Presidente da AMPP recebeu como propostas dos Dc. Portanto, também não tem conhecimentos sobre as propostas excluídas da agenda de debates e suas justificativas.

61 Especificamente sobre o funcionamento dos Órgãos Municipais do Pode Popular existem várias modificações no transcurso da sua existência. Sem pretender ser exaustivo e profundo nessa descrição histórica sobre as modificações mencionadas, pode-se começar falando sobre a aprovação da "Lei 1269 do Conselho de Ministros", do dia 3 de maio 1974. Também da aprovação em agosto de 1982 das "Normas Regulamentarias das Assembleias Provinciais e Municipais do Poder Popular". Essas normativas foram substituídas em 1995 pelo "Regramento das Assembleias Provinciais e Municipais do Poder Popular". Posterior a esse Regramento têm sido aprovadas outras normativas e acordos, como foram: o "Acordo $N^{o} .4047$ do Comitê Executivo do Conselho de Ministros. Regramento das Administrações Municipais e Provinciais do Poder Popular". Regramento, que ulteriormente foi substituído pelo "Acordo $N^{o} .6167$ do Comitê Executivo do Conselho de Ministros. Regramentos das Administrações Locais do Poder Popular". 
O desconhecimento dos atores sociais sobre essas demandas revelam limitações importantes para que a população consiga supervisionar a agenda de debates. Dessa forma, o presidente da AMPP tem maior oportunidade de incluir nos debates públicos somente aqueles temas do seu interesse, mesmo que essa agenda deva ser aprovada posteriormente no início da Sessão ${ }^{62}$. Tal aprovação não implica necessariamente uma distribuição de poder entre o governo e a sociedade civil na definição e supervisão dessa agenda. Além disso, não está estabelecido que o presidente tenha que informar os temas que recebeu e descartou, e os Dc's não têm liberdade para incluir uma temática concreta, se ela não foi previamente informada ao presidente da AMPP (ANPP, 1995).

Um último ponto em relação à dimensão analisada vincula-se a certas capacidades do OP que ainda não descritas e que constituem mais um aspecto divergente em comparação com a experiência cardenense. Esse ponto é precisamente o papel do OP e da AMPP no oferecimento de capacidades para acompanhar a definição da agenda dos debates, aspecto esse no qual, novamente, coincidem os critérios dos atores entrevistados em Porto Alegre.

Os próprios participantes do OP são os que, em maioria, colocam os temas que se discutem em cada espaço de debate e de participação, segundo os próprios atores. Esse processo se materializa mediante o trabalho dos Delegados e dos Conselheiros do OP, os FROP, e mediante o COP, instâncias de debates com as distintas Secretarias da prefeitura, que funcionam sobre a base dessas temáticas colocadas pela população e apresentadas por seus representantes eleitos:

O OP na verdade, tem hoje essas capacidades (supervisar, acompanhar). A população que participa do OP consegue acompanhar a definição das agendas de debates. Ele tem um ciclo e essa agenda vai se conformando a partir desse ciclo. Isto é o que talvez mantenha no OP algum grau de importância. Esse processo organizativo que falei antes permite acompanhar precisamente a definição da agenda. Porque essa agenda é feita pela própria população e desenvolvida pelos representantes que a população escolheu. Ou seja, os delegados

\footnotetext{
${ }^{62}$ As SeAMPP são dirigidas pelo presidente da AMPP, que tem a potestade para propor o encerramento do debate sobre determinada temática. Para isso, deverá outorgar a palavra para duas falas a favor e duas contra essa proposta, para posteriormente proceder com as votações (ANPP, 1995).
} 
são representantes das comunidades e os conselheiros são os representantes das regiões aonde pertencem essas comunidades. E eles são os responsáveis por acompanhar essa agenda e ao mesmo tempo por cumprir com essa agenda de debates. E a partir destas figuras a população vai acompanhando os debates que estão sendo feitos em cada espaço de debates ${ }^{63}$.

Assim sendo, esses debates posteriormente ficam registrados no site do OP e no PI anual, permitindo o acompanhamento popular dos assuntos tratados (a agenda) e das posturas adotadas pelos atores participantes e pela prefeitura. Além disso, os Delegados e líderes comunitários não só têm o dever de propiciar uma agenda de debates acorde com as necessidades dos cidadãos, mas também tem o dever de passar todas as informações para a população relativas às demandas, respostas, debates, etc.

Portanto, acerca desse ponto se conclui que essa agenda de debates vai se conformando em cada um dos espaços ou das instâncias de debates em cada região, assim como os delegados e líderes comunitários devem passar todas as informações para a população relativas às demandas, respostas, debates, etc.

Além dos FROP, outros espaços de participação dentro do OP foram reconhecidos pelos Conselheiros como forma de contribuir para que a população supervisione a definição da agenda dos debates em Porto Alegre. Novamente esses espaços são as reuniões do COP e o PI. Nas reuniões do COP, que são as "portas abertas" da população e de seus representantes, há a oportunidade de avaliar, discutir e/ou cobrar acerca das demandas feitas em função dessas prioridades.

Por outro lado, o PI, que é o documento público que recolhe as demandas populares e mostra as etapas de materialização dessas demandas, permite também que a população acompanhe as demandas e debates colocados por seus representantes:

\footnotetext{
${ }^{63}$ Falas de Vice-prefeitos, Gestores dos CARs, Conselheiros, Delegados e habitantes.
} 
(...) essas demandas vão para o plano de investimento e por aí a própria comunidade acompanha o processo do que foi debatido, entre outras coisas. Por esse plano a população chega a saber se as suas demandas foram debatidas, porque elas estão presentes no plano, é porque foram debatidas nos diferentes espaços de debates. Se não estiverem, eles pedem explicações dos seus delegados, conselheiros etc $^{64}$.

Dessa forma, observa-se que, segundo as experiências dos entrevistados, o OP contribui para que a população consiga acompanhar a definição da agenda de debates públicos. $\mathrm{O}$ argumento que sustenta essa ideia é que, em maioria, a própria população é a responsável por colocar os temas discutidos nos espaços de debate e de participação, como os FROP. Este espaço é reconhecido entre os atores como o principal mecanismo onde o povo é comunicado acerca dos diferentes processos pelos quais transitam suas demandas e prioridades e onde se estabelecem acordos e pautas para serem discutidas posteriormente ${ }^{65}$.

Perante as informações expostas relativas às três subdimensões que se analisaram, é possível observar que as experiências do OP e da AMPP não resultam tão distantes entre si, apesar de serem desenvolvidas em regimes políticos diferentes. Elas apresentam vários pontos em comum naquilo que se refere à facilitação de capacidades para que a população incida na configuração das condições da tomada de decisões. Por um lado, essas similitudes se fazem evidentes no fato de que, com suas particularidades, nenhuma das duas ferramentas tem sido eficiente na promulgação de debates referentes ao estabelecimento de mecanismos alternativos. Sendo assim, tanto as principais causas dessa ineficiência quanto alguns dos seus resultados, também exibem semelhanças.

Em ambos os casos, a não promulgação de debates sobre a criação de procedimentos alternativos está sustentada na ideia de que não é necessária essa

\footnotetext{
${ }^{64}$ Todos os atores entrevistados em Porto Alegre coincidiram em reconhecer as capacidades que oferece esse documento para o acompanhamento da gestão pública.

${ }^{65}$ Em cada Sessão do FROP, se realizam atas que são lidas nos encontros posteriores. Além disso, no início de cada encontro, os delegados e/ou conselheiros trazem informes sobre os processos das problemáticas ou demandas da região, com os debates que se têm realizados junto com o governo, etc. Esses informes são lidos, maiormente, quando tem FROP ordinários.
} 
ação, devido à centralidade que ambas as ferramentas adquirem no processo de debates nos seus territórios. Como resultado se observa, portanto, que o OP e a AMPP terminam monopolizando os processos democráticos, apesar das suas insuficiências, o que tem sustentado o reconhecimento do necessário aprimoramento destas experiências em relação ao fortalecimento do debate público e da tomada de decisões.

Somam-se a isso certas similitudes relativas às contribuições para favorecer discussões (refutação e ou aceitação) sobre normativas para regularizar a tomada de decisões sobre os assuntos públicos. Nas falas de atores mais vinculados à sociedade civil (habitantes e Delegados do OP e da AMPP respectivamente), foi comum a ideia de que as ferramentas em questão não facilitam uma distribuição de poder entre o Estado e a sociedade civil, diante da definição do marco normativo da tomada de decisões importantes sobre o território. As normativas que podem ser influenciadas são aquelas vinculadas a assuntos considerados "paliativos" das falhas do sistema social em geral. Dessa forma, tanto em Cárdenas quanto em Porto Alegre, os governos mantêm seu domínio sobre as lógicas que definem a tomada de decisões relativas às questões que constituem as determinantes das demandas mais recorrentes da população.

Por último, em relação às capacidades da população para influenciar nos modos de definir a agenda dos debates públicos e de supervisionar a definição dessa agenda, foram encontradas mais diferenças que semelhanças entre as ferramentas. Nessa comparação, o OP se mostra uma experiência com melhores resultados, como bem será aprofundado no último capítulo do presente estudo.

Em Porto Alegre se constatam melhores condições para que a população defina as condições sobre as quais será definida a agenda de debates, enquanto que, em Cárdenas, não há experiências dessa índole. O motivo dessa inexistência é que o governo tem sido responsável pela configuração dessas normativas pela própria agenda de debates. De igual maneira, em relação às capacidades para supervisionar a definição da agenda de debates, o OP apresenta melhores resultados, tanto pelo 
papel que cumprem nesse processo não só os diferentes espaços de debates dentro do ciclo do OP junto com os Delegados e Conselheiros, quanto pela função do conhecido PI. Essa situação se visualiza de forma limitada na experiência da AMPP em Cárdenas, apesar de, desde o ponto de vista normativo, os Dc tenham a obrigação de acompanhar o desempenho dos diversos assuntos públicos no município. 


\section{OP E AMPP EM PERSPECTIVA COMPARADA: CONTROLE DOS ATORES POLÍTICOS E DAS DECISÕES}

Enfatizando a comparação das contribuições que o OP e a AMPP fazem à democratização das decisões sobre os assuntos públicos, é necessário desenvolver uma segunda fase analítica na atual pesquisa. Dessa forma, os conteúdos que se apresentam nessa seção mostram uma comparação entre o OP e a AMPP, no que se refere às capacidades que tais instâncias oferecem para que a população exerça controle sobre os atores políticos e sobre as decisões relativas aos assuntos públicos. Esta ação se sustenta na concepção de um dos objetivos específicos previstos: analisar as similitudes $e$ diferenças nas capacidades de controle sobre os atores políticos e sobre as decisões que, mediante a execução do OP e da AMPP, exercem diferentes atores locais em Porto Alegre e Cárdenas, respectivamente. Para tanto, analisar-se-á o papel do OP e da AMPP na socialização de informações e nas capacidades instaladas para que a população avalie a gestão governamental em função dos assuntos públicos, bem como as capacidades de sanção que essas ferramentas promovem sobre os atores políticos.

Serão analisados, também, três aspectos essenciais das similaridades e diferenças entre OP e AMPP no que concerne às capacidades para o controle das decisões. No primeiro momento descrevem-se as capacidades que ambas as ferramentas oferecem para que a população influencie na definição das políticas públicas. Posteriormente, se apresentam essas semelhanças e diferenças em relação às contribuições do $\mathrm{OP}$ e da AMPP para facilitar que os cidadãos sejam informados e possam debater sobre as decisões a serem adotadas e executadas. Por último, descrevem-se como ambos os mecanismos contribuem para supervisionar a execução das decisões tomadas no território. 
No fim da atual seção, apresenta-se também um breve resumo dos pontos comuns entre ambas as experiências democráticas, embora eles sejam abordados mais profundamente no último capítulo.

\subsection{Socialização de informações e avaliação da gestão governamental em função dos assuntos públicos}

O controle sobre os atores políticos, dimensão analisada neste capítulo, se dá de formas diversas em ambas as instâncias analisadas. Em Porto Alegre, os sujeitos entrevistados (Gestores dos CARs, Vice-prefeitos, Conselheiros, Delgados e habitantes) ofereceram valorações positivas no que tange às capacidades instaladas pelo OP para que a população seja informada sobre a gestão dos atores políticos (relacionadas com as demandas púbicas) e as suas justificativas e, além disto, possa avaliar essa gestão.

Foram reconhecidas duas formas mediante as quais o OP contribui para o mencionado processo. A primeira forma é através dos Delegados, Conselheiros, e/ou líderes comunitários, que têm acesso à prefeitura e podem ser convidados para participar de algumas reuniões do governo. Além disso, podem solicitar despachos pertinentes diretamente com os membros da prefeitura. Tais papéis favorecem o acesso às informações sobre a gestão do governo, que posteriormente deverão ser passadas para a população. Deve-se, no entanto, ressaltar o principal papel que cumprem os FROP e o COP, como espaços onde essas informações são socializadas e onde, inclusive, os atores do governo são convidados para prestar contas da sua gestão e suas justificativas.

Sobre a função dos FROP e do COP no processo em questão, Conselheiros, Delegados, Vice-prefeitos, habitantes e Gestores dos CARs declaram que nesses espaços a população consegue ter informações diretas acerca da gestão do governo e as justificativas de suas ações devido à própria dinâmica que ali se desenvolve. Nos FROP, por exemplo, as distintas Secretarias da prefeitura são chamadas regularmente para prestar contas em relação à sua gestão. No COP, por sua vez, são discutidas e avaliadas 
essas ações, as decisões tomadas, as grandes normativas e a forma como foram executadas, entre outros assuntos. Esse processo conta com a participação ativa dos Conselheiros $^{66}$ (representante do povo) que têm voz, voto e devem passar todas as informações relacionadas com a gestão do governo para as suas comunidades:

\begin{abstract}
Os delegados e conselheiros têm a missão de cumprir com essas funções. Por exemplo, os Conselheiros que participam no COP conseguem ter informações acerca da gestão do governo e depois passam as informações para as comunidades e/ou os delegados que, inclusive podem até assistir às reuniões no COP, porque elas são abertas. Também as secretarias quando a população precisar são chamadas para os FROP para elas prestar contas sobre algumas situações de interesse para a gente. Os conselheiros têm capacidades até para solicitar reuniões com o prefeito. E isso favorece ter informações sobre a gestão do governo. Nas reuniões do COP, onde se discutem as grandes normativas, os Conselheiros participam ativamente e ai eles devem passar todas as informações para as suas comunidades, relacionadas com a gestão do governo. Sim. Disso não posso reclamar. O OP facilita ter informada a população, pelo menos a população que frequenta o OP. Os FROP e o COP fazem com que a população tenha as informações necessárias sobre a gestão governamental em função das demandas que eles fizeram. (...) Os Conselheiros têm que trazer para o COP o que está acontecendo lá na sua região e nos FROP, como também levar para os seus representados o que está acontecendo no COP.
\end{abstract}

Outra forma para o OP potencializar as oportunidades descritas é o Plano de Investimento (PI), onde evidenciam-se as obras previstas e em processo de execução, bem como as que foram entregues. Por tais motivos, o documento em questão constitui, além de uma referência para a gestão governamental em termos de execução de investimentos, uma ferramenta de apoio à prestação de contas da administração municipal nas Assembleias. Igualmente representa uma forma de constatação das demandas públicas e um mecanismo de transparência e controle social do governo por parte da população. Todas essas questões favorecem o fluxo de informações sobre a gestão dos atores políticos e as suas justificativas.

\footnotetext{
${ }^{66}$ Um dado importante sobre o papel dos Conselheiros nesse processo é que, no caso de não participarem em três ocasiões consecutivas no COP, podem ser substituídos por algum dos conselheiros suplentes, com o objetivo de garantir a obtenção de informações e potenciar a participação popular nos assuntos públicos.
} 
O conjunto de sujeitos que foram entrevistados na experiência em Cárdenas (Dc, habitantes, Pcp.), por sua vez, ofereceu argumentos aceitáveis no que tange às capacidades da AMPP para facilitar que os/as cardenenses sejam informados/as sobre a gestão dos atores políticos (relacionadas com as demandas públicas) e as suas justificativas e, além, possam avaliar essa gestão. No entanto, sem descartar certas limitações existentes.

Desse modo, foram reconhecidas várias formas mediante as quais se contribui para o mencionado processo no caso de Cárdenas. A primeira forma é através dos Dc, os quais têm acesso à prefeitura e participam de diferentes reuniões no governo. Além disso, podem também solicitar despachos pertinentes diretamente com os membros da prefeitura. A outra forma são as próprias Rc e as SeAMPP, como espaços onde são socializadas informações e onde, inclusive, os atores do governo podem ser convidados para prestar contas da sua gestão e apresentar as justificativas de suas ações. Esses três procedimentos, junto com as funções do Dc, favorecem o acesso da população às informações sobre a gestão do governo:

Desde la formación de los Gobierno se creó una estructura y por esta se le da conocimiento a la población del estado del gobierno y la solución de los planteamientos. Se obtienen las informaciones y justificaciones a través de la gestión del delegado. El espacio de las Rc y las Sesiones de la AMPP es buena porque propicia intercambio entre la población y puede tener conocimiento en general de que sucede en el municipio $(\ldots)^{67}$.

Nesse cenário, os DC aparecem como atores centrais no processo de socialização de informações sobre a gestão governamental, como se pode constatar através das normativas que regem suas funções e pelo reconhecimento das pessoas entrevistadas.

Os Dc têm como principal dever trabalhar no Órgão do Poder Popular que ele integra, procurando soluções para as problemáticas colocadas pela população. Além disso, compete-lhe o conhecimento periódico sobre a gestão da AMPP, do

\footnotetext{
${ }^{67}$ Falas de habitantes, Dc e Pcp em Cárdenas.
} 
Conselho de Administração Municipal e sobre a projeção do trabalho no território para, entre outras questões, cumprir eficientemente suas funções. Entre elas destacam-se tramitar à AMPP as opiniões, necessidades e dificuldades dos seus eleitores e, simultaneamente, informar para eles sobre sua gestão do governo em relação ao tratamento das problemáticas do território (ANPP, 1999, 1995).

Os principais espaços onde as funções dos Dc se materializam são as Rc e as SeAMPP. As Rc, por exemplo, são destacadas normativamente como a principal via para socializar informações relacionadas às problemáticas da população e para promover a análise coletiva das mesmas na procura de possíveis soluções:

"El delegado está obligado a reunirse con sus electores por lo menos dos veces al año, con el objeto de rendirles cuenta de su gestión personal, previa programación aprobada por el presidente de la Asamblea Municipal. Estas reuniones constituyen, además, una vía para informar a los electores sobre la situación en que se encuentra la circunscripción, el Consejo Popular, el municipio, la provincia y el país, promoviendo el análisis colectivo en la búsqueda de soluciones en la participación popular" (ANPP, 1995, Art. 60).

As SeAMPP, que também se configuram como um mecanismo central nos processos de socialização de informações sobre a gestão governamental, são definidas pelas normativas assim como as Rc. Entre outras questões, elas têm a missão de dar a conhecer os resultados conseguidos mediante as atividades de determinadas instituições locais, assim como informar sobre o cumprimento dos acordos e disposições adotados pela AMPP em sessões anteriores. Além disso, é da sua competência notificar sobre os estudos realizados pelas Comissões de Trabalho que se considerem pertinentes a serem submetidos à AMPP, e promover a prestação de contas dos Delegados à AMPP e o Conselho de Administração Municipal, quando corresponda (ANPP, 1995). Por último, mais um elemento que falicita as funções descritas das SeAMPP, é o dever de serem publicados nos órgãos locais de divulgação (rádio, imprensa, etc.) os acordos de interesse geral adotados pela Assembleia e nas suas sessões. 
"El Orden del Día puede incluir asuntos como los siguientes: a) el estado de cumplimiento de los acuerdos y disposiciones adoptados por la Asamblea Municipal en sesiones anteriores; b) las decisiones de carácter general adoptadas por el presidente que deban ser consideradas por la Asamblea; c) el informe de rendición de cuenta del Consejo de la Administración Municipal, cuando corresponda; (...)”. (ANPP, 1995).

Tais argumentos mostram certas similaridades relacionadas ao papel do OP e da AMPP no assunto que se trata; no entanto, também é possível apreciar algumas limitações em ambos os casos. Particularmente sobre a experiência em Porto Alegre, se constatou que as pessoas que participam dos debates nos marcos do OP são uma baixa porcentagem (aproximadamente 1\%) em comparação com a densidade populacional dessa cidade, sendo usualmente pessoas com maiores desvantagens socioeconômicas.

Essa situação faz com que grande parte da população de Porto Alegre não se encontre bem informada sobre a gestão dos atores políticos e suas justificativas, sobretudo aquela parte da população com melhores condições econômicas, porquanto as populações dos bairros "periféricos" são as que têm uma relação mais cotidiana com o poder público.

Por esses motivos os entrevistados em questão afirmam a necessidade de maior divulgação do OP, seja por internet ou por outras vias. Essa maior divulgação se daria não só com o objetivo de tentar envolver mais pessoas e facilitar assim a renovação das lideranças, mas também para aumentar as possibilidades de serem priorizadas as demandas de certos bairros, pela quantidade de pessoas que as sustentariam.

Por outro lado, e embora não tenha sido uma situação recorrente nas falas dos entrevistados, também existem alguns atores que mostraram certo grau de discordância com o papel que cumprem os Conselheiros, especialmente no que tem a ver com a tomada de decisões em função dos interesses do povo e com a 
socialização de informações nas comunidades. Essa situação foi registrada na fala de alguns Delegados e habitantes de Porto Alegre:

Nem sempre a população se manteve informada. Os conselheiros participam das reuniões onde podem ter acesso às informações sobre a gestão pública (o COP e as próprias reuniões com as secretarias), mas tem conselheiros que nem sempre trazem as informações para as comunidades. Tem alguns que se acham donos do processo e até tomam decisões sozinhos sem consultar os FROP. O maior problema do OP é que muitos delegados, conselheiros e etc., que supostamente devem responder aos interesses do povo, são confiscados pela política. A política consegue envolver eles. E estou falando das pessoas que são remunerados e não remuneradas. Para aqueles que não são remunerados a estratégia é mediante a visibilidade. A política tenta fazer sentir importantes as nossas lideranças, dão boas atenções (comprometem eles com favores) e ai eles depois não têm coragem para brigar com o governo. Eles não vão comprar uma briga com aquele lado onde estão se sentindo bem. E até porque eles então passariam a ser vistos como desagradáveis pelo governo depois dessas atenções, e isso eles não querem. Então são poucos os líderes que não estão desse lado. O compromisso do OP com uma política comunitária que deveria unificar as pessoas independentemente da natureza das associações, não existe mais. E muitas lideranças comunitárias acabam sendo cooptadas pela institucionalização.

No caso de Cárdenas, as limitações mais reconhecidas têm uma natureza diferente. A primeira delas é que, na prática, os altos funcionários do governo municipal não estão habitualmente presentes em espaços como as Rc. A frequente ausência dos atores do governo nestes espaços limita as capacidades da população para receber de primeira mão as informações e justificativas pertinentes sobre a gestão do governo, bem como para avaliá-la. A outra limitação é que nem sempre os Dc são informados completamente sobre a gestão governamental em função dos assuntos públicos:

En la última rendición de cuentas las personas exigieron ser escuchadas y que las instituciones que estaban inmiscuidas en las problemáticas tenían que estar en las asambleas, fueron muy críticas. Las Rc y las Sesiones de la AMPP es buena porque propicia intercambio entre la población y puede tener conocimiento en general de que sucede en el municipio, solo que queda inconcluso porque la personas que deben dar respuesta no están presente en las rendiciones de cuenta y demás. (...) me siento herida cuando los electores te dicen cosas que no han llegado a ti. (...) siento que la toma de 
decisiones debe mejorar y nos deben decir las cosas en tiempo. En ocasiones el consejo de la administración toma decisiones y no se le informa al delegado, por tanto no llega a los electores ${ }^{68}$.

Diante dessas circunstâncias, os entrevistados colocaram exemplos nos quais se observa como as capacidades da população para obter informações relacionadas com os assuntos públicos são afetadas. Um desses exemplos foi a nova divisão político-administrativa que unificou os antigos municípios de Cárdenas e Varadero para formar um único município (Cárdenas). Os habitantes revelaram não ter conhecimentos claros sobre os argumentos que sustentaram este acontecimento em particular, nem sobre o papel dos atores políticos e seus representantes perante esse processo. Segundo os sujeitos que buscaram informações a respeito, a resposta dada por seus representantes foi que essa política se configura como uma decisão de nível nacional.

Hoy por hoy yo no sé que por qué unieron Cárdenas con Varadero. Algunos dicen para ayudar económicamente a Cárdenas. Otros porque la población en Varadero es muy poca como para conformar un municipio. Pero en realidad, no sé. Cuando he preguntado a Delegados sobre la decisión de unir Cárdenas con Varadero, me dicen que eso fue una decisión de 'arriba' y que eso no nadie lo discute ${ }^{69}$.

Outro exemplo similar foi a política de demolição de moradias (ou partes delas) no próprio território de Varadero. A população e alguns Dc também desconhecem a gestão do governo em relação a esse ponto no que concerne aos seus fundamentos e às ações do governo (pesquisas, diálogos com população, etc.) para chegar à sua execução.

Um último aspecto a ressaltar sobre as limitações da $\mathrm{AMPP}^{70}$, no âmbito da socialização de informações e do favorecimento à avaliação da gestão governamental, é a necessidade de oferecer uma maior divulgação sobre a realização das mesmas. No âmbito comunitário, as Rc geralmente têm suficiente divulgação,

\footnotetext{
${ }^{68}$ Falas de habitantes, Dc e Pcp em Cárdenas.

${ }^{69}$ Esse trecho resume as falas de habitantes, Dc e Pcp em Cárdenas.

${ }^{70}$ Sobre a base da execução de um dos seus principais espaços de debates: SeAMPP.
} 
mas não é a mesma realidade no caso das SeAMPP. Para a maioria dos entrevistados, uma maior divulgação da realização das Sessões favoreceria não só possíveis debates sobre as problemáticas do território, mas também uma maior socialização das informações, o que beneficiaria as avaliações sobre a gestão governamental.

Dessa forma, Porto Alegre apresenta maior viabilidade pelo ponto de vista prático no que se refere às capacidades oferecidas para avaliar a gestão dos atores governamentais, apesar de que as funções dos atores que facilitam esse processo sejam similares em ambas as latitudes ${ }^{71}$. Nesse sentido, mais uma vez e de forma unanime, os entrevistados em Porto Alegre manifestaram que essa avaliação se materializa a partir do momento em que os Secretários da prefeitura, quando necessário, ofereçam respostas para os Conselheiros e Delegados de cada região no que concerne às suas ações em função das demandas populares. Esse processo é possível devido ao papel dos Conselheiros e a possiblidade de terem contato direito com a prefeitura. Um exemplo se encontra nas seguintes palavras de alguns dos entrevistados:

O OP é uma ferramenta fundamental para facilitar a avaliação dos atores políticos frente às demandas populares. Devido a que tudo passa pelo OP, aí tem facilidades para saber o que está sendo feito e o que não está sendo feito. O que se vai fazer e o que não. Além de que essas relações próximas entre as comunidades, os seus líderes, o OP e o governo facilita também que a população faça essa avaliação. Acredito que o OP vai funcionar como um termômetro para o governo. (...) a gente tem o respaldo e vai lá com peso para bater a porta do governo e reclamar explicações para a população e ao mesmo tempo explicar para eles que a coisa não é do jeito que eles falam. Como Conselheiros temos a função de acompanhar a gestão do governo e de avaliar eles em função do que fazem com as demandas

\footnotetext{
${ }^{71}$ Em Cárdenas, do ponto de vista normativo, o governo tem o dever de informar para os representantes do povo (Dc e Pcp) sobre sua gestão em função dos assuntos públicos. Em função desse processo, esses atores também têm poder para estabelecer vínculos com o governo e facilitar a obtenção de informações. Em Porto Alegre, se visualiza a mesma realidade, através dos Delegados e Conselheiros do OP. A diferença consiste em que, em Porto Alegre, o processo é mais eficiente e tem mais recursos para que a população obtenha essas informações e possa avaliar, independentemente das formas da cultura política nesta última cidade, que facilita também o mencionado processo.
} 
populares. Participamos do COP, podemos solicitar reuniões direitas com a prefeitura, etc. ${ }^{72}$.

Entretanto, a possível falta de informações por parte da população para avaliar a gestão dos atores políticos pode ser suprida nos espaços de debates anteriormente descritos, os FROP e os COP. Tais espaços, conforme já foi mencionado anteriormente, contribuem para socializar informações relativas à gestão governamental, sendo também o local onde os diferentes secretários responsáveis por certas temáticas podem ser chamados para prestar informações sobre as sua gestão, de acordo com a necessidade da população:

O FROP e o COP funcionam como ferramenta para acompanhar e fiscalizar o andamento das obras, projetos e demandas. Além de que neles se cobra do governo pela execução dessas coisas. Também nesse COP se discutem e analisam entre outras coisas a forma em que estão acontecendo as obras ou o funcionamento do governo. E tudo isso oferece capacidades para avaliar sobre a base das informações que vão nós chegando ${ }^{73}$.

Por outro lado, as capacidades outorgadas pelo OP para a referida avaliação, também são assistidas pelo já mencionado PI. Esse documento, realizado anualmente como base para o ano seguinte, é um plano de acesso ao público, onde constam as obras que foram escolhidas para serem financiadas e executadas (além de informações sobre o estado de cumprimento das mesmas). Assim, é possível que a população tenha argumentos para avaliar a gestão pública em função das demandas populares.

(...) o PI facilita isso porque é um documento onde estão todas as obras que deveriam ser feitas num período determinado e em qualquer espaço de debate você pedir para o governo ou para os representantes do governo presente, informações sobre esse andamento e ai avalia a gestão governamental. O PI é a principal ferramenta. Este regimento é feito pelas comunidades e não pelo governo, através dos Conselheiros regionais que veem para o COP. Nesse COP é discutido, debatido,

\footnotetext{
${ }^{72}$ Respostas de Conselheiros, Gestores dos CARs, Delegados, Secretários da Prefeitura e habitantes da população que participam do OP.

${ }^{73}$ Falas de Conselheiros, Vice-prefeitos, Gestores e Delegados em Porto Alegre.
} 
alterado e decidido esse regimento. Embora tenha coisas nesse regimento que são relativas ao governo, e que ele também altera. Mas somente é colocado no regimento ou aprovado se passar pelo COP. $\mathrm{Ou}$ seja, se governo quiser mudar alguma coisa que de critérios técnico ou outro aspecto, que pode afetar a comunidade, o COP não aprova. (...) além do acompanhamento que fazemos pelo Plano de Investimento, que facilita avaliar a gestão da prefeitura ${ }^{74}$.

Outros indicadores da existência dessas capacidades do OP podem ser visualizados a partir da criação do Observatório de Porto Alegre (OBSERVAPOA) ${ }^{75}$ e das cobranças realizadas ao governo através do OP. Entretanto, sobre as cobranças ao governo por parte da população em decorrência das deficiências ou insatisfações encontradas, já foi declarado que no OP elas são concebidas como parte do processo de democratização. Isso, segundo as opiniões dos atores que expressaram suas experiências, é o resultado das avaliações políticas diretas que a população pode fazer através do OP sobre a gestão do governo e em relação às demandas e aos acordos estabelecidos. Sobre o aspecto em questão, expressou um dos Secretários da prefeitura:

Ele (o OP) é um termômetro do estado geral de animo das comunidades. Inclusive é importante até como ferramenta de manutenção ou derrubamento do governo. E essa manutenção ou não, são realizadas sobre a base das avaliações que a população faze dos atores políticos em função das suas demandas ${ }^{76}$.

\subsection{Capacidades de sanção sobre os atores políticos}

Prosseguindo com a análise sobre o funcionamento dos mecanismos em questão e seus papéis no controle dos atores políticos, é preciso examinar a maneira

\footnotetext{
${ }_{75}^{74}$ Falas de atores como: Vice-prefeitos, Gestores, Conselheiros e Delegados.

${ }^{75}$ OBSERVAPOA é uma ferramenta criada pela própria prefeitura que analisa e publica informações sobre tudo o que está acontecendo em cada região do OP na cidade. Para obter mais informações sobre OBSERVAPOA, visitar o seguinte endereço: WWW.obervapoa.com.br

${ }^{76}$ Falas de Conselheiros, Vice-prefeitos, especialistas.
} 
como oferecem capacidades para que a população exerça sanção ${ }^{77}$ sobre tais atores. Como bem se conhece o OP não é um mecanismo reconhecido juridicamente. Por conseguinte, ele não tem capacidades para estabelecer sanções aos atores políticos a partir de um ponto de vista legislativo. No entanto, como acordo e forma democrática estabelecida entre o governo e a população, tem capacidades para estabelecer outros tipos de sanções baseadas nas pressões políticas.

As cobranças feitas pela população ao governo sobre determinados temas implicam certas pressões políticas que por vezes deixam em estado de constrangimento os atores governamentais. Os delegados, Conselheiros e demais representantes do OP, tem força para pressionar os atores governamentais frente à gestão em função das demandas populares e, assim, conseguem estabelecer certas tensões:

Hoje o OP é uma grande força dentro do governo. O OP tem um poder político muito grande, mesmo que não tenha um poder legislativo. Ele consegue tencionar para que sejam debatidas e solucionadas algumas demandas e problemáticas da população, que inclusive algumas vezes estão pendentes. Então isso é a forma em que eu vejo que o OP sanciona aos atores políticos. (...) se o governo trabalhar direitinho com o OP, esse governo vai maiores possibilidades de se manter no poder. A gente volta pressão neles e sanciona desde um ponto de vista político, porque a cooperação com a gente pode definir a aceitação ou não do governo na população. Nada é perfeito, porque temos que lutar muito, mas a gente tem esse poder. A outra forma de sancionar é mediante a mídia, a internet, etc. As coisas mal feitas o governo sabe que vão ser promovidas e a população vai terminar sabendo. E isso pode afetar o seu governo. O OP é tão forte que pode até derrubar um governo, se ele quiser. A população consegue fazer algum tipo de sanção, $\operatorname{sim}^{78}$.

Segundo os atores entrevistados, essas capacidades de sanções políticas têm produzido ou facilitado o afastamento do cargo de vários funcionários do governo,

\footnotetext{
${ }^{77}$ Entre os gestores entrevistados destaca-se a imprensa como outro mecanismo de sanção, além do OP: "Outra forma de sanção tem sido a imprensa. Sempre reconhecendo que ela não é imparcial, que ela responde a certos interesses dos políticos, econômicos etc., mas sem dúvidas deve ser vista como uma ferramenta de sanção porque ela muitas vezes também cobras dos atores políticos. No caso da licitação do transporte público, por exemplo, a imprensa cobrou muito disso".

${ }^{78}$ Falas de Vice-prefeitos, Gestores, Conselheiros, Delegados e especialistas.
} 
como governadores, Secretários, vereadores, etc., sendo esta a principal forma de sanção que o OP dispõe. É por isso, entre outros aspectos, que a prefeitura tenta estabelecer boas relações com o OP e fazer uma boa gestão sobre a base das demandas e necessidades do povo. Inclusive, o poder do OP nesse sentido faz com que qualquer governo que queira concorrer nas eleições não declare planos de extinção do OP. Do contrário, seria difícil sua manutenção na concorrência:

\begin{abstract}
Através da pressão que a população exerce no governo, acho que se dá essa sanção. Eles sabem que se as coisas não marcham bem com o OP, podem ter dificuldades para exercer seu cargo ou perder legitimidade como um bom governo. Ele (o OP) tanto te coloca nas alturas quanto te derruba. (...) tenho colegas de trabalho que têm sido afastados ou trocados do cargo porque não correspondiam â comunidade e esta não queria mais interagir com eles. O governo que hoje deseje acabar com o OP não teria êxito na sua campanha. Se o governo está trabalhando direito com o OP, ele vai ter uma gestão mais fácil. Se fosse o contrário o OP vai dar trabalho. Então o OP sanciona desde o ponto de vista político, social. (...) no meu entender o OP foi essencial para manter o PT durante tantos anos no poder e também para fazer perder ele a eleição ${ }^{79}$.
\end{abstract}

As capacidades de sanção descritas também têm contribuído para estabelecer certas condutas no âmbito governamental. As Plenárias anuais, por exemplo, constituem um espaço onde o perfeito, os Secretários da prefeitura e os diretores de departamentos, entre outros, não se dispõe a participar se não tiverem feito uma boa ou pelo menos uma aceitável gestão dos assuntos públicos. Por esses motivos, a maioria dos atores expressou que o governo geralmente tenta resolver os problemas levantados antes de chegar nessa assembleia, evitando, assim, a pressão e o controle que exerce a população frente ao descumprimento dos acordos estabelecidos:

(...) na aquela assembleia anual, onde está toda a cúpula do governo e onde as comunidades vão reivindicar tudo ao mesmo tempo, se o governo descumprir com o que foi prometido, teria uma forte manifestação com batucadas, bandeiras, barulho e as comunidades vão vaiar ao prefeito, secretários etc. E o governo sabe disso e não querem passar por esses momentos. Por isso, o governo sempre vai tentar

\footnotetext{
${ }^{79}$ Falas de Vice-prefeitos, Gestores, Conselheiros, Delegados e especialistas.
} 
fazer ou iniciar as obras e cumprir com demandas antes de chegar esse dia.

A outra conduta que o OP consegue pautar tem a ver com o posicionamento dos agentes governamentais frente às críticas e aos enfrentamentos da população. Mesmo que em espaços como as Plenárias anuais, Sessões do COP e os FROP, esses agentes levem fortes críticas, isso não implica algum questionamento dos seus ideais políticos. Esse fato demonstra que o OP facilita a convivência e o debate político na base do respeito, mesmo com as criteriosas diferenças, o que é fundamental para o desenvolvimento de qualquer sistema democrático.

Essa forma de convivência faz com que as críticas feitas pela população ao governo não sejam entendidas de forma subversiva por parte da administração. Isso demonstra que a administração, cientemente ou não, reconhece que a população possui seus direitos de expressão e de questionamento, ao mesmo tempo em que reconhece seus próprios deveres e obrigações de governar o município a partir das necessidades e interesses do povo.

Desse modo, com base nessas capacidades de sanção, o OP tem facilitado uma interação entre governo e sociedade civil, em que a população mais humilde consegue graus de empoderamento que facilitam o diálogo e o relacionamento direto com o governo. Da perspectiva dos entrevistados, esta situação seria impossível em outros cenários políticos e sociais, devido ao elitismo que usualmente caracteriza os espaços governamentais em distintas sociedades. Sobre isso, expressa um dos Conselheiros:

O OP é além de uma ferramenta política, uma ferramenta social, porque faz um empoderamento a pessoas que em outros momentos ou espaços não teria como ter o poder para falar de frente com o governo. Pessoas sem estudos, que moram nos piores bairros, até com piores aparências em termos de vestimenta, mas são os nossos lideres comunitários que contribuem com o governo de uma maneira tremenda para melhorar as nossas vidas. Ou seja, o OP da um protagonismo para eles. 
Assim sendo, essas formas de sanção exercidas sobre os atores políticos em Porto Alegre, mostraram poucas similaridades com experiências em Cárdenas. Nesta cidade, a partir das formas de funcionamento da AMPP e das características empíricas das suas Sessões e das Rc, os sujeitos entrevistados demonstraram que não concebem essas ferramentas com capacidades para estabelecer sanções diretas aos atores políticos. Entre as poucas ideias expressadas pelos entrevistados sobre esse ponto, se ressaltou que particularmente as SeAMPP, seus Dc, Pcp e a população em geral não tem capacidades para exercer essas sanções; os entrevistados nem sequer associam as SeAMPP e as Rc com oportunidades para, do ponto de vista subjetivo e/ou político, construir uma base crítica que possa, posteriormente, decorrer em sanções:

No está instituido dentro de los reglamentos de la Asamblea que los electores, delegados ni presidentes de consejos populares sancionen. $\mathrm{Ni}$ las SeAMPP ni las Rc son espacios que brindan oportunidades para que la población sancione a los gobernantes. A los gobernantes los sancionan los mismos gobernantes desde los niveles superiores ${ }^{80}$.

A ausência dessa associação faz com o grau de cobranças que, no caso de Porto Alegre, se efetuam mediante o OP e que constituíam as principais formas de sanção sobre o governo, não seja uma realidade comum na execução das SeAMPP em Cárdenas. Portanto, na prática, as Sessões não constituem uma força política em mãos da população, que potencialize capacidades para sancionar os atores governamentais por meio do estabelecimento de certas tensões e pressões a fim de fazê-los cumprir com o dever de governar desde e para o povo.

No entanto, apesar das citadas barreiras na ordem democrática, existem certos meios para que a população controle de alguma forma os atores políticos. Esses meios são configurados a partir de um ponto de vista estrutural e normativo e se concretizam na figura dos Dc eleitos pelo povo. Nesse sentido, as sanções consistem basicamente no afastamento dos cargos governamentais.

\footnotetext{
${ }^{80}$ Falas de Pcp, Dc e habitantes em Cárdenas.
} 
De forma concreta, na figura dos Dc constam as capacidades da população para exercer sanções, propondo a destituição dos seus cargos de: Dc; deputados à ANPP, Presidente e Vice-presidente da AMPP e da APPP; Presidente, Vicepresidente e Secretários da ANPP, assim como membros do Conselho de Estado (ANPP, 1999, art. 3). As revocações são independentes de qualquer procedimento em matéria penal, civil administrativa ou laboral e, particularmente, sobre o nível organizativo e governamental que ocupa neste trabalho, o municipal, tem-se os seguintes motivos pelos quais podem ser destituídos os Dc, os deputados da ANPP e o Presidente e Vice-presidente da $\mathrm{AMPP}^{81}$ : por descumprimento reiterado das obrigações derivadas do seu cargo; por incorrer em fatos que o façam desmerecer o bom conceito público e/ou por manifestar conduta incompatível com a honra de representar o povo num órgão do Poder Popular (ANPP, 1999: art. 5) ${ }^{82}$.

As propostas para revogar o mandato dos Dc podem ser feitas por mais de $25 \%$ dos eleitores e/ou por petição de outro Delegado à AMPP. Neste caso, as capacidades de sanção são exercidas diretamente pela população sobre seus representantes eleitos. Para revogar os deputados à ANPP, as petições podem ser realizadas pelo Conselho de Estado, por outro deputado ou pelos 25\% (como mínimo) dos Delegados do município onde esse deputado foi eleito. Finalmente, a revogação do mandato do Presidente e do Vice-Presidente da AMPP se dá por solicitação do Presidente ou Vice-Presidente da APPP ou por um Delegado da própria AMPP. Ou seja, para esses dois últimos cargos mencionados, a população exerce suas capacidades de sanção e destituição por meio dos seus representantes eleitos, os Delegados. Para isso, eles deverão seguir os trâmites pertinentes que variam segundo os atores que fizeram a solicitação.

\footnotetext{
${ }^{81}$ Para uma análise das obrigações desses atores governamentais, ver ANPP (1995, 2010).

${ }^{82}$ Não foi possível encontrar outros documentos que explicitem mais as implicações das citadas causas para a revocação. Mais informações nesse sentido, podem oferecer dados importantes sobre as capacidades de sanção que a população pode exercer por meio das SeAMPP. Particularmente, seria necessário identificar se a falta de respostas às preocupações do povo, a tomada de decisões sem contar com a população ou o as atitudes de desrespeito ou de represália aos cidadãos por motivo das suas críticas ou ideias referentes à gestão do governo são considerados aspectos que fazem incorrer nas causas estabelecidas para a revocação.
} 
"Los facultados para promover el inicio del proceso de revocación del mandato hacen la solicitud mediante escrito fundado y según el caso puede ser propuesta: 1) Cuando se trate de un delegado a la Asamblea Municipal por: a) otro delegado a la Asamblea Municipal; b) un veinticinco por ciento, como mínimo, de los electores de la circunscripción por la que fue elegido. 3) Cuando se trate de un diputado a la Asamblea Nacional, por: a) el Consejo de Estado. b) otro diputado, c) un veinticinco por ciento, como mínimo, de los delegados a la asamblea del municipio por donde fue elegido. 4) Cuando se trate del Presidente o el Vicepresidente de la Asamblea Municipal o de ambos a la vez, por: a) el Presidente de la Asamblea Provincial, b) un delegado a la propia Asamblea Municipal (ANPP, 1999, p. 4-5).

Como prova da projeção prática das capacidades anteriores, alguns entrevistados declararam que em algumas ocasiões tiveram conhecimento de destituições de atores políticos, como resultado do funcionamento da própria AMPP. No entanto, nenhum deles conseguiu lembrar algum exemplo concreto.

Colocadas as capacidades e limitações associadas ao papel das SeAMPP como veículo da população para exercer sanção sobre atores governamentais, é necessário destacar mais um dado interessante. $\mathrm{O}$ posicionamento dos entrevistados em relação às suas capacidades para sancionar aos atores políticos mediante as Sessões está associado a uma maneira específica desses atores se apropriarem do mecanismo em questão. Essa maneira é precisamente o motivo pelo qual as relações entre a população e os atores governamentais em Cárdenas não estão profundamente marcadas por enfrentamentos físicos e/ou verbais, que por vezes podem representar crises de estabilidade política.

Assim sendo, essas formas de apropriação dos Dc, Pcp e habitantes em geral sobre as SeAMPP consistem em assumi-las como um dever do governo, já executado de maneira formal, no lugar de assimilá-las como um direito (instituído além) de todo cidadão cubano, de exercer suas capacidades para controlar os atores políticos e sancioná-los. Esse movimento se configura como um genuíno reflexo das capacidades democratizantes que devem ter a sociedade civil sobre a gestão governamental, em função dos assuntos públicos. 
Uma última questão a ser tratada sobre as capacidades de sanção do OP e da AMPP sobre os atores governamentais é que as limitações nesse sentido não estão exclusivamente presentes na experiência em Cárdenas. Em Porto Alegre também foram apresentadas algumas deficiências, pese às capacidades de sanção que a maioria dos atores tem reconhecido no OP. Entre os Delegados do OP e moradores de Porto Alegre, se percebe certa insatisfação com as capacidades do OP para sancionar os atores governamentais por causa dos habituais descumprimentos e/ou irregularidades.

A primeira insatisfação tem haver com a quantidade de atrasos na execução de obras ou demandas populares que, inclusive, datam de anos (às vezes por responsabilidade do governo, outras por responsabilidade das empresas). Frente a essa problemática, alguns Delegados e moradores alegam que o OP não tem tido suficiente poder para exigir que as demandas sejam cumpridas no tempo estabelecido por meio de outra forma que não seja com tensão. Alegam que, mesmo provocando tensão no governo, existem questões não resolvidas que afetam os interesses do povo, como é o processo burocrático (ou "burro-crático" segundo expressão do entrevistado) que dificulta a execução de obras: as secretarias têm funções dividas (uma coloca os postes, outras as lâmpadas, outra traz a terra, etc.) e às vezes nem dialogam entre si.

A outra insatisfação está relacionada com certas irregularidades no âmbito financeiro, o que tem afetado a execução de obras e frente a qual o OP tem-se visto limitado. Segundo os atores mencionados, essas questões demonstram que as capacidades de sanção política e social que hoje tem o OP não são suficientes para fazer com que sejam respeitados os interesses do povo ${ }^{83}$.

\footnotetext{
${ }^{83}$ Em relação a essas limitações existem critérios divergentes sobre a forma como poderiam ser resolvidas. A principal limitação está dada, segundo a maioria dos atores entrevistados, pelo fato de o OP não ser reconhecido legalmente. Sobre esse fato, alguns atores pensam que é viável legalizar esse mecanismo e, assim, conseguir maiores capacidades de sanção sobre o governo. No entanto, outros não acham viável essa opção e alegam duas questões fundamentais. A primeira é que o governo conseguiria cooptar o OP, se ele chegasse ser legalizado. Quer dizer, ele deixaria de ser um mecanismo popular e independente do governo. E a segunda é que alguns afirmam que essa legalização entraria em conflito com as funções da Câmara de Vereadores.
} 
(...) eu acho que se a população se unisse mais com o OP, tudo fosse melhor. O OP é respeitado, é forte e muito vendido. Mas eles mesmos não se valorizam (...) ao mesmo tempo são corrompidos. Um exemplo foi que a gente ganhou a iluminação pública da nossa comunidade (que é do município, e mediante o OP tinham sido liberados 300 mil reais para colocar as lâmpadas). Mas: cadê elas? Sumiram! Perguntei para Buzzato e ele não sabe. Perguntei para os Conselheiros do OP e ninguém deu respostas, falando: a gente vai ter que ver; esse dinheiro está perdido. E isso tinha sido incluído inclusive no Plano de Investimento $^{84}$.

Como definido no início do capítulo, outra área a ser analisada no que concerne às capacidades de controle que o OP e a AMPP outorgam aos cidadãos é o campo das decisões tomadas. O primeiro aspecto a considerar nos marcos das capacidades de controle das decisões sobre os assuntos públicos é precisamente o papel das mencionadas ferramentas na definição das políticas públicas, o que será analisado no tópico a seguir.

\subsection{Definição das Políticas Públicas}

A forma como as políticas públicas são definidas e a participação das instâncias analisadas nessa definição possuem aspectos que devem ser destacados. No caso de Porto Alegre, constata-se que o OP oferece certas capacidades à população para incidir na definição de políticas públicas. No entanto, entre os sujeitos entrevistados as avaliações sobre o reconhecimento dessas capacidades não resultam homogêneas. Mais uma vez, se acharam diferenças de critérios entre Gestores dos CARs, Conselheiros, Vice-prefeitos e habitantes e Delgados do OP.

Na perspectiva dos Gestores dos CARs, Conselheiros e Vice-prefeitos, na maioria das regiões de Porto Alegre há obras que provavelmente não teriam sido construídas se o OP não existisse. Nesse sentido, Gestores alegam que esse processo de execução de políticas públicas associadas à construção de obras tenha sido

\footnotetext{
${ }^{84}$ Falas de Delegados e habitantes.
} 
mediado por técnicos que não vivenciam a realidade do local e que, dentro de uma sala, olhariam as estatísticas, achando talvez que:

Por exemplo, em certo bairro se precisaria de creches porque existe certa quantidade de crianças. Mas esquecendo de que poderia ser que esse bairro, pelas suas características socioeconômicas, já esteja suprido de escolas. Sendo assim que outra comunidade poderia não entrar nesse mapa de avaliação, mesmo que precisar essa creche. Então é ai quando o OP interfere nesse processo para orientar a execução dessas possíveis obras, fazendo com que exista uma colaboração e com que as decisões do governo, algumas delas, passem pelo OP.

As falas dos Conselheiros e Vice-prefeitos, por exemplo, coincidem com as falas dos Gestores, alegando que o OP tem esse tipo de capacidades, o que facilita uma visão mais real sobre as comunidades, necessária para o governo e suas políticas. Portanto, nesse sentido, destacam a importância do OP como processo que consegue dar voz à população para que as políticas sejam feitas em função das suas necessidades:

O governo tem uma visão de cima e nós daqui de baixo. E por isso o governo pede para a gente participar da construção das políticas públicas. Em geral, eu acho que o OP é uma ferramenta fundamental. (...) Então, basicamente, não tem definição de políticas públicas sem o OP. Hoje, Porto Alegre não tem condições de sobreviver sem o OP. É uma coisa que está enraizada na população. O próprio governo se sente meio perdido sem o OP. Porque ele é um norte para o governo. Então existem muitas coisas que demonstram que o OP tem capacidade para incidir diretamente na definição de políticas ao nível do bairro e às vezes até ao nível municipal.

Para argumentar sobre essas capacidades que os atores mencionados reconhecem no OP, foram apontados vários fatos ilustrativos: a troca de ônibus em Porto Alegre, a colocação de Delegacias no município (fato que tem uma dependência Estadual), construção de creches, reformas de postos de saúde, a troca de paradas de ônibus para que as pessoas desçam em lugares mais seguros e 
próximos das suas casas, além da colocação de lâmpadas de iluminação para uma maior segurança à noite.

Somados a esses exemplos, foram mencionados outros por parte dos Viceprefeitos, como a construção do Porto que, mesmo sendo uma obra institucional, teve que passar pela LOA e ter um aval do OP (FROP e COP). Em relação à questão do Porto, um dos Vice-prefeitos afirmou:

Qualquer coisa (demanda ou obra) que vai ser feita no município, inclusive as obras institucionais, tem que passar por dentro do OP. Por exemplo, tem uma obra que vai sair agora, que é o caso do Porto, ela teve que passar pela Lei Orçamentária Anual (LOA), pelas temáticas, ou seja, pelo OP. Mesmo que o dinheiro não seja da prefeitura, tem que ter o aval do OP. Então essa é uma forma de incidir na definição de políticas públicas.

Também foi mencionada a Licitação do Transporte público ${ }^{85}$, onde se discutiu sobre algumas linhas de ônibus e sobre o fato de colocar ou não ar acondicionado nesses ônibus, entre outros aspectos como a criação do Conselho de Usuário. No referente a essa Licitação, os Vice-prefeitos expressaram que inicialmente a posição do governo foi de resistência, pois esta ação deveria encarecer mais o valor da passagem (que já se encontra cara). Mas, diante dessa posição do governo, houve reações por parte da população, porque consideravam (90\%) que os ônibus deveriam ter ar acondicionado, mesmo que houvesse aumento da passagem.

Considerando isso, a prefeitura pediu para o OP que o assunto fosse debatido em cada região para, ulteriormente, tomar decisões. Finalmente, defini-se no projeto de Licitação do transporte público que os ônibus deveriam ter ar acondicionado. Esse processo demonstrou para esses atores que as capacidades do OP para incidir

\footnotetext{
${ }^{85} \mathrm{Na}$ colocação desse exemplo, também coincidiu a maioria dos Conselheiros do OP, junto com os Viceprefeitos e Gestores dos CARs. Os debates sobre esse fato foram levados para OP e realizados nas 17 regiões para depois fazer parte duma discussão mais ampla em toda a cidade, numa audiência pública. E ao fim das contas se decidiu que os ônibus deveriam ter ar acondicionado, além de outras outras decisões como, por exemplo, o passe livre uma vez por mês.
} 
na definição de políticas públicas existem não somente no nível microssocial (bairro, comunidade), mas também ao nível macrossocial (melhorar a qualidade do transporte coletivo na cidade).

Outro exemplo colocado por esses últimos atores mencionados foi a própria estrutura territorializada do OP, que consiste em dividir a cidade em 17 regiões administrativas. Esta ação existe por causa dos debates realizados nos marcos do OP que alterou a gestão da prefeitura na definição das políticas públicas, segundo os critérios dos Vice-prefeitos. Dessa forma se facilitou um governo mais descentralizado, levando a prefeitura a cuidar obrigatoriamente das "periferias" ou das áreas mais vulneráveis da cidade.

Ao mesmo tempo, todos os atores reconheceram que desde o momento em que o OP é chamado para discutir sobre a execução de certas decisões (como a licitação do transporte público), já é um passo na incidência da população na definição das políticas. Não é uma população muito ampla (porque, maiormente, participam aquelas pessoas mais humildes e carentes de certos recursos), mas de qualquer modo existe uma incidência nesse processo, que poderia ser maior se participassem mais pessoas. Além disso, existem várias Comissões ${ }^{86}$ que debatem constantemente com o governo as decisões ou políticas a serem executadas, tendo inclusive acesso direto ao governo, o que facilita a influência nas decisões.

De forma mais concreta, se constatou também que o fato de os Conselheiros poderem apresentar as demandas e inquietudes das suas regiões nos diferentes espaços de debates possibilita criar uma tensão nas pautas no governo, permitindo que as demandas sejam debatidas e materializadas. Também as PR constituem uma base para a definição de políticas públicas do governo, cujos resultados são evidentes a partir de certas conquistas: postos de saúdes (Vila Graciana, Glória, etc.) creches, escolas de ensino infantil (obras entregues para instituições sem fins lucrativos e que funcionam em pareceria com o setor privado), construções de

\footnotetext{
${ }^{86}$ No RI se definem as formas em que elas são criadas, assim como a sua relação com o COP e os Delegados (PMPA, 2015).
} 
moradias (Programa "Minha casa minha vida", ações de cooperativismo no âmbito habitacional - COMPHA), saneamento básico, pavimentação, etc.

Outros exemplos que demonstram as influências do OP na definição de políticas se fazem visíveis na demarcação de obras de zona 30 (parte da cidade onde se diminui a velocidade dos carros) e, ainda, destacam os grandes empreendimentos que são realizados como contrapartidas em diferentes regiões. Um exemplo desses empreendimentos é a construção do Shopping no CAR Cristal, sobre a base de discussões para decidir onde seria executada a obra, entre outros assuntos.

O conjunto de elementos até aqui mostrados sobre o OP e a definição das políticas públicas oferecem uma ideia concreta das capacidades que tem esta ferramenta para incidir no mencionado processo. Entretanto, o caso de Cárdenas não apresenta as mesmas características, podendo ser destacas duas questões importantes. A primeira delas é que os dois principais espaços da AMPP (Rc e as SeAMPP) não oferecem capacidades suficientes à população para incidir na definição de políticas públicas, como afirmam alguns entrevistados. A segunda é os entrevistados apresentaram impressões homogêneas sobre o reconhecimento da limitação dessas capacidades.

No entanto, antes de explorar essas falas, é necessário destacar os fatos que chamam a atenção enquanto reflexos das potenciais capacidades das SeAMPP para incidir na definição das mencionadas políticas. $\mathrm{O}$ primeiro deles a possibilidade de, através das SeAMPP, dar voz e votos para os Dc como representantes do povo. O segundo fato, ligado ao anterior, são as oportunidades que elas oferecem para que a população, mediante seus representantes (Dc), possam apresentar suas problemáticas e inquietudes. Em terceiro lugar, observa-se a interação entre o governo e a sociedade civil diante dos assuntos públicos para a qual estão destinadas a contribuir as mencionadas Sessões. Por último, se destacam as funções das chamadas Comissões de Trabalho (temporais ou permanentes), criadas pela AMPP e integradas por Delegados da própria AMPP, com o propósito de, entre outras questões, realizar estudos sobre a realidade cultural, social e econômica do território 
(ANPP, 1995). Esses quatros aspectos constituem fatores que facilitam uma visão mais real sobre as comunidades, o que pode influir na definição de políticas públicas.

Não obstante, na prática se percebe que esses fatores não conseguem provocar tensões suficientes no governo, levando-o a orientar as políticas em função de algumas necessidades e preocupações da população. De acordo com a perspectiva dos Delegados e habitantes, isso está evidente no conjunto de deficiências que ainda persiste na execução de algumas políticas públicas e na prestação de certos serviços públicos. Entre essas políticas e serviços se destacam: saneamento em alguns bairros de Cárdenas; a demolição parcial e/ou total de moradias em Varadero; injustiças no pagamento da eletricidade em algumas moradias em Varadero ${ }^{87}$; entre outros. Por conta dessas insuficiências, os mencionados atores consideram imprescindível aprofundar a participação popular para melhorar a definição e execução de políticas públicas, alegando que elas não deveriam ser impostas pelo governo:

Lo primero es que indiscutiblemente la sabiduría están en las masas. Por ejemplo, si se escuchara lo que dice la población sobre cómo marchan los servicios públicos hoy no estuviesen funcionamiento con tantas deficiencias. Es necesario estimular la participación de la población, sobre la base de buenas decisiones, ello es lo único que hace creíble el sistema. Desde mi punto de vista, el gobierno hace caso omiso de los que se plantea en las SeAMPP y las Rc para definir las políticas públicas. Creo que las facultades para incidir están establecidas, lo que las limita son los estilos y métodos empleados por las personas y los responsables de las instituciones, que ni responden a estas facultades ni garantizan la participación.

${ }^{87}$ Essas injustiças estão associadas á proibição de divisão das propriedades que foi mencionada anteriormente. Devido à diversidade geracional que muitas vezes convivem dentro de uma mesma casa, muitos membros de uma mesma família optam por fazer divisões físicas dentro da própria casa, com o propósito de ganhar maior privacidade. Mas essas famílias têm maiores despesas no pagamento da eletricidade em comparação com outras famílias. Está estabelecido pelo governo, que cada casa deve ter um só medidor de consumo de eletricidade por cada propriedade e os valores aumentam gradualmente na medida em que se aumenta a quantidade de kilowatts consumidos (até os 100 kilowatts o valor é X. Entre 100 e 150 o valor é XX, e assim paulatinamente). Diante dessa situação, é muito mais fácil atingir os níveis de consumo com maiores taxas de pagamento, provocando um descontrole do consumo pelo qual cada fração familiar é responsável. Do outro lado, se cada fração familiar tivesse sua propriedade junto com seu medidor de eletricidade independente, seria mais baixo o pagamento e mais fácil para organizar a responsabilidade pela quantidade de eletricidade que na realidade cada fração familiar consume. 
Em relação às deficiências mencionadas, a realidade de Cárdenas demonstra outros aspectos que limitam as capacidades das SeAMPP para incidir da definição de políticas públicas. Similar ao OP em Porto Alegre, a eficiência desse mecanismo está determinada, principalmente, pela questão financeira, entre outros aspectos. Geralmente os recursos financeiros disponíveis para o município não são suficientes para investir nas problemáticas mencionadas, pois se deve garantir primeiramente a manutenção de políticas públicas básicas e universais como educação (creches, escolas de todos os níveis excetuando o universitário) e saúde (policlínicos, hospital, farmácias, clínicas odontológicas, etc.).

Por outro lado, a pouca autonomia dos governos locais cubanos para dirigir os seus municípios se estabelece como outra das limitações que afrontam as SeAMPP para incidir na definição de políticas. As políticas públicas em Cárdenas e no país em geral não apresentam esferas diversificadas para sua definição, conforme acontece em Porto Alegre: Federal, Estadual, Municipal. Em sua grande maioria as políticas públicas são definidas no nível central do Estado e posteriormente executadas em cada região do país. Não existem fontes variadas de poder para a definição da maioria das políticas.

Portanto, nesse contexto, os governos municipais não têm liberdade plena para defini-las e modificá-las na sua essência, sendo as SeAMPP um espaço limitado e que deriva da estrutura governamental na qual está inserida. Exemplo disso são as problemáticas referentes às políticas executadas em Varadero, associadas à moradia, eletricidade, nova divisão político-administrativa, etc. ${ }^{88}$.

Sobre o caso das demolições em Varadero, por exemplo, tanto a decisão em si mesma quanto a forma de executar essa política refletem as limitações que têm sido declaradas. Numa das SeAMPP, vários Dc expressaram suas inconformidades com vários aspectos dessa política. Em primeiro lugar, a questão das moradias em

\footnotetext{
${ }^{88}$ A política centralizada do Estado cubano na definição de algumas políticas (educação, saúde, esporte, cultura), tem servido para garantir o acesso universalizado a esses bens. No entanto, ela também tem contribuído para minimizar as capacidades democratizadoras de mecanismos como as SeAMPP, bem como para limitar o desenvolvimento de formas da cultura política mais criticas sobre a realidade.
} 
Cuba ainda não é uma problemática totalmente resolvida, apesar da promessa realizada pelo Comandante Fidel Castro desde o ano 1953, no chamado "Programa del Moncada" ${ }^{, 89}$. Diante disso, para muitos Dc, ao invés de demolir as construções já existentes, outras soluções deveriam ser discutidas, sobretudo, e situando o segundo argumento, considerando-se que por detrás dessas construções existia um grande esforço da população para resolver as suas situações, além de um mau funcionamento da "Direção Municipal de Vivenda" 90, órgão governamental encarregado de fazer cumprir as normativas relacionadas com esse assunto no território.

As respostas do governo municipal às colocações realizadas pelos Dc nessas SeAMPP não satisfizeram as expectativas de alguns dos Dc, tampouco tem satisfeito a maior parte dos habitantes de Varadero. Para os funcionários presentes nesse espaço, nada mais havia para se fazer a respeito por ser uma decisão proveniente do nível nacional de governo.

Considerando as ideias expostas, pode-se entender então que as SeAMPP têm certa parcela de poder para influenciar certas linhas das políticas públicas que, como parcela ao fim das contas, tem suas limitações. Essas limitações fazem com que suas capacidades estejam mais ligadas ao âmbito comunitário, e não precisamente vinculadas aos processos de elaboração estratégica da cidade. Como resultado dessa situação, esse mecanismo tem perdido a credibilidade como espaço real de exercício democrático sobre os assuntos públicos.

Quisiera que cambiaran lo métodos y estilos de dirección del territorio en la busca de soluciones, pues estos no potencian la sinergia entre todos los actores. Los espacios que yo conozco (Asambleas Municipales, rendiciones de cuentas), se han convertido en espacios donde se tramitan inquietudes sobre el territorio y se reciben

${ }^{89}$ O "Programa del Moncada" apresentava as principais problemáticas de Cuba antes do Triunfo da Revolução, que seriam o guia dos esforços a serem realizados pela nação cubana toda vez que foram conquistadas as liberdades públicas e a democracia política posterior a esse triunfo. Esse Programa foi declarado por Fidel Castro como autodefesa no seu julgamento por ter assaltado vários quartéis militares, o que tem sido chamado de "La Historia de Absorverá".

${ }^{90} \mathrm{O}$ mau funcionamento consistiu em que pela Lei era supostamente proibida qualquer obra construtiva em Varadero. No entanto, por determinadas razões algumas pessoas obtiveram permissão junto à Direção Municipal de Vivendas é, mesmo assim, foram afetadas mediante a política em questão. 
informaciones acerca de determinadas cuestiones y/o proyectos ya decididos. (...) hay que ir más allá y lograr implementar otros espacios que, aún cuando no sean oficiales sí son necesarios, porque los oficiales ya no son los que mejor o más facilitan la participación ${ }^{91}$.

Apesar dos resultados positivos achados sobre o $\mathrm{OP}$ e as limitações encontradas sobre a AMPP, foi possível visualizar algumas limitações em Porto Alegre através da fala de alguns atores, limitações estas que tem pontos de contato com as experiências em Cárdenas. Para alguns Delgados e habitantes de Porto Alegre, as políticas públicas têm várias esferas: Federal, Estadual, Municipal, bem como os Conselhos ligados a essas esferas: Conselhos de Educação, de Saúde, etc. Todas essas entidades têm poder de decisão nas diretrizes das políticas públicas, sendo este cenário um arranjo complexo.

Portanto, nesse cenário, o OP tem uma parcela do poder para influir em certas linhas das políticas públicas, mas com certas limitações. Assim, as capacidades do OP também estão mais ligadas ao âmbito comunitário, ao espaço mais mediato. E no processo de elaboração estratégica da cidade, o OP não tem influência e nem tem conseguido fomentar esse processo, segundo os atores mencionados. Ou seja, em frente à interrogação “qual é a cidade que queremos?”, o OP não oferece uma resposta à população.

Um exemplo das insatisfações geradas por essas limitações, colocado como um ponto positivo pelos Gestores dos CARs, Conselheiros e Vice-prefeitos, foi a questão dos Shoppings na região Cristal. Entre os habitantes e Delegados que foram entrevistados persiste o questionamento sobre a viabilidade de construir esses Shoppings e/ou Centros Comerciais, quando a própria população dessa região necessita de um condomínio popular. Sobre a base do fato descrito, alegam que, nesse caso, o OP não tem conseguido fazer um enfrentamento com o "capital" no município:

\footnotetext{
${ }^{91}$ Falas de Pcp, Dc e habitantes em Cárdenas.
} 
E no processo de elaboração estratégica da cidade, o OP não tem influência e nem tem conseguido puxar esse processo. Ou seja, que cidade a gente quer? Por exemplo, a questão dos Shoppings. Não tem um enfrentamento com o capital no município. Quando o OP surge, muitas diretrizes das políticas públicas foram geradas dentro do OP (Habitação). E essas coisas têm sido mentidas durante muito tempo e estão sendo inclusive descumpridas. Então o que vale é a grana. Manda quem pode e obedece quem precisa.

Concomitantemente a essas falas, foi destacado pelos sujeitos entrevistados que a questão financeira constitui outra das limitações do OP para provocar grandes impactos na vida cotidiana da população. Sobre isso, afirmam que os recursos financeiros que são destinados para o OP são escassos e não permitem resolver as principais problemáticas do povo. Além disso, segundo esses atores, o conjunto de obras que se consegue fazer dentro das comunidades relacionadas a questões como esgoto, creches, etc., são insuficientes em comparação com o que a população precisa e o OP deve fazer.

Incide muito pouco. A verba que é destinada para o OP é muito pouco é não dá para fazer nada de grande impacto. Se tivesse mais verba de repente até daria um maior impacto nas comunidades mais carentes. Mas antigamente era bem melhor esse processo. O OP era mais dinâmico e mais conversado. O governo só mantém o OP porque dá visibilidade para ele.

Essas questões fragilizaram a credibilidade do OP entre algumas pessoas, provocando tanto o afastamento de alguns habitantes do OP quanto a ideia de que esta instância é mantida pelo governo apenas para buscar visibilidade, ideia esta existente tanto entre os habitantes quanto entre os Delegados.

\subsection{Contribuições para informar e debater (refutar e aceitar) decisões a serem executadas}

Por outro lado, com o propósito de analisar as capacidades que o OP e a AMPP facilitam para o controle da população sobre as decisões relacionadas a 
assuntos públicos, também se faz necessário analisar a contribuição que esses mecanismos fazem no que se refere a duas ações fundamentais. A primeira delas é informar à população sobre as decisões relativas aos assuntos públicos antes de elas serem adotadas e executadas. A segunda é discutir (aceitar e/ou refutar) essas decisões com a população antes das suas respectivas execuções.

Nesse sentido, o OP mostra alguns resultados positivos, conforme expressaram muitos dos entrevistados (Gestores dos CARs, Conselheiros, agentes da prefeitura). Segundo eles, nos espaços de debates estabelecidos (FROP e COP) também se oferecem informações sobre as decisões antes de elas serem executadas. Caso os Secretários não deem as respostas necessárias, esse ponto fica marcado como um acordo a ser debatido no próximo FROP. Esta situação é passível de acontecer com todas as secretarias, porquanto está determinado que todas elas devem passar no transcurso do ano pelos FROP.

Em relação a este processo, ressaltou-se o papel dos Conselheiros como facilitador dessas informações para a população. O fato de esses Conselheiros participarem nos FROP e terem acesso ao governo mediante reuniões, encontros, etc., contribui para que as informações sobre as decisões sejam socializadas antes de serem executadas.

Sem dúvidas contribui. O FROP vai funcionar como um fiscal desses processos também, porque lá são informadas e debatidas as decisões que o governo pretende executar. E são informações que chegam à população mediante os conselheiros que participam no COP e que também tem acesso ao governo. O governo não faz nada, nem decide nada sem passar pelo OP. (...) tudo o que o governo pretende executar, passa pelo OP antes de ser executado, tanto para informar, quanto para debater, decidir, etc.

Igualmente e com a intenção de oferecer uma melhor descrição desse processo, os Gestores e Conselheiros revelam que, normalmente, as decisões do governo não são definitivas, pois passam pelo $\mathrm{OP}$ e são debatidas com as comunidades. Concretamente, depois das demandas da população passar pelos 
FROP, se faz um relatório que é encaminhado para a secretaria de Planejamento orçamentária. Neste ponto se define a disponibilidade de orçamento para a obra, o qual é informado para os Gestores dos CARs e outros representantes do OP, com o objetivo de que essas informações sejam passadas para a população. Às vezes essas informações não chegam até a base, e as deliberações são feitas entre os Delgados e Conselheiros. Mas não é uma situação geral, segundo as falas dos gestores em questão:

Todas as demandas da população passam pelo FROP. Posteriormente, o relatório é encaminhado para a secretaria de Planejamento orçamentária. Aí eles definem a disponibilidade de orçamento para a obra e a gente vai lá, se informa para depois vir e passar as informações para a população. (...) às vezes essas informações não chegam até a base, (...) não é uma coisa geral, mas acontece. (...) dificilmente o governo diz: nós vamos trocar isto de aqui para lá, pronto. Não, isso passa pelo OP primeiramente e aí então se dá essa socialização de informações sobre as decisões antes de elas serem executadas.

Alguns exemplos nos quais se manifestam esses processos são os casos da Estátua do Laçador e do Novo Código Municipal de Limpeza Urbana. A Estátua do Laçador está situada na saída do aeroporto (importante símbolo de identidade da cidade). Em determinado momento o governo decidiu trasladá-la, mas mudou de ideia depois dos debates com a população, estabelecidos a partir das informações previamente socializadas sobre essa decisão.

Em relação ao Novo Código Municipal de Limpeza Urbana os resultados foram similares. O Novo Código foi um projeto de Lei de iniciativa do poder executivo, sobre o qual houve uma ampla discussão com as comunidades e com a sociedade em geral. Uma das instâncias que se procurou foi o OP, não só para a discussão do projeto, mas também para auxiliar na divulgação junto às comunidades $^{92}$.

\footnotetext{
${ }^{92}$ Também foram chamadas as escolas, as entidades de classes, as igrejas etc., instituições que ao final das contas concentram o OP.
} 
Associado às anteriores capacidades do OP para manter informada a população sobre as decisões antes de sua execução, observou-se que também há a viabilização de discussões para aceitar ou refutar essas decisões antes da sua execução. Entre os Gestores dos CARs, Conselheiros, vice-prefeitos e alguns habitantes foi possível notar um consenso em relação às oportunidades oferecidas pelo OP para contribuir no aspecto da democratização das decisões sobre os assuntos públicos. Tais capacidades foram demonstradas sobre a base de experiências concretas onde certas decisões do governo foram refutadas ou discutidas antes de serem aprovadas. Destacou-se também que, em muitas ocasiões, a prefeitura tem inclusive solicitado que o OP se manifeste, opine e discuta sobre as decisões, pois isso constitui certa garantia de aceitação da gestão do governo. Este fato contrasta com as experiências do governo anterior, que esteve envolvido num processo judicial por fazer obras sem antes discutir ou informar ao OP e à população em geral.

(...) se bem o governo não consegue fazer nada ou quase nada (porque ele pode até fazer, só que vai ter briga) sem informar ao OP, ao mesmo tempo a questão não é só informar. O governo pede que o OP se manifeste, opine e discuta sobre as decisões que pretendem ser tomadas. Sim. As decisões sempre são informadas para o $\mathrm{OP}$ e discutidas. E também muitas vezes a gente consegue mudar algumas coisas nesse sentido. Já teve o caso do governo da eleição passada, que fiz obra sem discutir nem informar para o OP e para a população, e ele foi denunciado e entrou num processo judicial. Porque ele usou a "máquina pública" para benefício próprio, em benefícios políticos próprios porque pretendia obter votos a partir da construção dessa obra.

Entre as experiências mais emblemáticas que foram mencionadas estão a Licitação do transporte público ${ }^{93}$, a assembleia na Câmara de Vereadores para

\footnotetext{
${ }^{93}$ Sobre esse processo um dos entrevistados declarou: "tem-se debatido intensamente sobre isso junto à população. Já foram feitos duas licitações e acabou se trocando os termos da licitação em função das demandas da população. O governo entende que deve ser feita duma maneira e a população entende que deve ser feita de outra, como não tem como manter se fosse assim. Até que hoje se chegou ao médio termo. Por exemplo, uma das contradições era a questão do ar acondicionado em todos os ônibus. A população exigia isso. Só que a população não tinha noção do custo que isso teria e que ao final das contas isso ia repercutir no valor da passagem. Até que finalmente e a partir dos debates a população entendeu isso".
} 
regularizar áreas de interesses sociais, as propostas de mudanças de divisões de bairros na região Cristal e as remoções na Vila Chocolatão (região Central) e na Vila Nazaré (região Norte) com base em interesses econômicos e sociais do governo.

No caso das propostas de mudança de divisões de bairros, os moradores não concordaram porque uma parte de certos bairros (ruas, quadras) seria excluída dos seus territórios. Por esses motivos os habitantes dessas áreas demandaram por intermédio do OP a reavaliação dessa situação, o que resultou na modificação do projeto e na anulação da divisão. Essas decisões foram, inclusive, debatidas numa audiência pública. Por outro lado, no que se fere às mencionadas Vilas, as decisões do governo estiveram e ainda estão paralisadas até se conseguir um acordo entre governo e moradores.

Outro exemplo que manifesta o poder do OP para aceitar ou rebater as decisões do governo antes de sua aprovação ou execução foi a própria regulamentação do OP. Segundo os interesses do governo, houve a proposta de regulamentação do OP por parte da prefeitura, que foi rejeitada pela ação da população e do OP. Outro caso foi a tentativa de regulamentar que os Gestores dos CARs tivessem educação superior, como condição indispensável para assumir o cargo. A partir da oposição dos Conselheiros, essa decisão não foi executada, porquanto os próprios Conselheiros e a população consideraram que, para responder aos interesses da população, não era necessária essa condição.

Também, por exemplo, já teve decisões que foram rejeitadas. Uma delas foi a regulamentação do OP. O governo apresentou uma proposta para fazer isso. Mas o OP não aceitou. Eu lembro que o governo queria que os gestores dos CARs tivessem educação superior. Eles queriam fazer com que isso fosse uma condição imprescindível. $\mathrm{E}$ ai os conselheiros não aceitaram, porque na verdade esses CARs tem que responder aos interesses da comunidade e não precisa ser desse jeito. Então os conselheiros se reuniram, bateram a porta do prefeito e isso teve que ser mudado ${ }^{94}$.

\footnotetext{
${ }^{94}$ Falas dos Conselheiros em Porto Alegre.
} 
Não entanto, ainda se encontram restrições em relação às capacidades do OP para contribuir que a população obtenha informações sobre as decisões a serem executadas, bem como propiciar debates para refutar e aceitar as decisões. Atores como Delegados, alguns Conselheiros e habitantes em geral expressaram que, apesar da refutação de algumas decisões pontuais, isso acontece sobretudo em âmbito local, e mais concretamente, no nível dos bairros. No âmbito das políticas macro, no entanto, se torna mais difícil materializar o processo citado. Dentro das políticas macro do município, se distinguem algumas questões essenciais que deveriam ser discutidas e reavaliadas, mas o poder do OP para isso é limitado. Uma dessas questões é o impacto do capital sobre a realidade social e as desigualdades da população.

(...) já aconteceu que o governo quer fazer uma obra e o OP interfere para que ela não seja feita. Agora no âmbito de políticas macro, ai é mais difícil. Aí acontece que dentro dessas políticas macro, algumas questões pontuais podem ser barradas. Que na verdade não seria nem barradas, porque o OP não tem poder de barrar. Muitas decisões se discutem além de ser informadas. Agora, não lembro algum processo inteiro que tenha sido barrado por causa do $\mathrm{OP}^{95}$.

Alguns desses atores expressaram que desconheciam a ocorrência de alguma rejeição de decisões na sua totalidade ${ }^{96}$. A explicação oferecida nesse sentido foi que o governo geralmente indaga entre a população antes de criar, tomar e/ou propor alguma decisão para o OP. Dessa forma, quando as decisões são propostas para debate, geralmente já trazem na sua lógica uma parte das vontades da população, dificultando sua rejeição. Para o governo, é mais conveniente que os lideres populares concordem o máximo possível com as decisões, porque reconhecem que os seus pensamentos serão provavelmente aceitos entre a maior parte da população:

(...) o governo sente que nesse caso o OP é um termômetro. Porque se eles veem que se esses líderes estão pensando de certa forma, então assumem que mais para frente a maior parte da população não vai concordar com certas decisões. A refutação de decisões

\footnotetext{
${ }^{95}$ Falas de Delegados, alguns Conselheiros e habitantes em Porto Alegre.

${ }^{96}$ Foi o caso de um dos habitantes e de um dos vice-prefeitos entrevistados.
} 
governamentais por parte do OP acontece muito pouco. Mas acontece pouco por quê? Porque quando o governo está trazendo alguma coisa ele já teve em conta o OP e a população para trazer alguma coisa que na verdade na gente precise. Ou seja, ele já estudou a proposta ${ }^{97}$.

No que se refere às contribuições da AMPP para informar a população sobre as decisões relativas aos assuntos públicos antes de serem executadas, se discernem detalhes de uma realidade mais limitada, em comparação com a experiência do OP. Tanto as Rc quanto as SeAMPP contribuem para manter informada a população sobre as decisões relativas aos assuntos públicos, mas nem sempre essas informações são oferecidas antes que as decisões sejam adotadas e, só às vezes, se informam previamente à sua execução. Segundo a maioria dos entrevistados, o que geralmente acontece é que o governo informa as decisões depois de serem concebidas, deixando a população expressar suas opiniões e/ou criticas ao respeito, mas sem visualizar necessariamente mudanças posteriores.

Nesse sentido, as experiências dos atores de Cárdenas envolvidos nesta pesquisa não se lembram de momentos em que decisões importantes no território tenham sido adotadas e informadas, tendo como base os critérios e os discursos da população, como se pode constatar na fala a seguir:

En determinados casos se han analizado las decisiones con los electores antes de ejecutarlas, por ejemplo la unión de Varadero con cárdenas, aunque no siempre sucede98. Casi siempre lo que te informan es lo sucedido en la asamblea de lo que ya fue decidido. No se dice por ejemplo que tomando en cuenta los planteamientos tuvimos que decidir tal cosa. No creo que tengamos una incidencia real en las decisiones tomadas en el territorio, porque no se escucha la voz de los Delegados para tomar esas decisiones ni para responder a las necesidades reales de los electores. Esto ocurre en un $70 \%$ de los casos. Algo que se contradice con lo que yo tenía pensado sobre el rol de los delegados.

\footnotetext{
${ }^{97}$ Falas de Vice-prefeitos, Gestores e Conselheiros em Porto Alegre.

${ }^{98}$ Aqui o entrevistado não expressou que foi informado sobre essa decisão antes de ela ser tomada, sendo informado apenas quando já estava decidida a sua execução.
} 
Assim, com base nas expressões de atores como Dc, habitantes e Pcp, em Cárdenas não é usual que as decisões sejam debatidas com a população para depois serem adotadas e executadas. Essa situação constitui o principal motivo pelo qual muitos cidadãos aspiram que em algum momento a tomada de decisões parta verdadeiramente da população e sobre a base de uma explicação das causas e problemáticas que as sustentam:

Esta institucionalizado dentro de los documentos rectores de las AMPP, que el Dc por planteamientos de sus electores puede derogar ciertas decisiones tomadas y este convocar una sesión extraordinaria para ello. A veces creo que los delegados tampoco reúnen las condiciones o no saben trasmitir las informaciones, por lo general lo que hacen es leer un informe del municipio que viene preconcebido y no son explícitos los problemas. En lo que respecta a las SeAMPP e $\mathrm{Rc}$, eso se ha convertido en el lugar donde la gente sólo plantea sus inquietudes, pero no recibe suficientes respuestas. (...) las facultades para incidir están establecidas, lo que las limita son los estilos y métodos empleados por las personas y los responsables de las instituciones, que ni responden a estas facultades ni garantizan la participación. El problema de gobierno y de la toma de decisión, parte del control y tiene que formar parte también la población. Hay que velar porque la toma de decisiones llegue a la población y porque se expliquen las causas por las cuales se toman.

Somente uma minoria de decisões relacionadas a serviços específicos são debatidas com a população antes da sua adoção e execução. Entre essa minoria destacam, por exemplo: o sentido de determinadas vias na cidade, os lugares específicos para a parada dos "coches" ou os planos de investimentos para a instalação hidráulica de determinadas circunscrições.

Os entrevistados apresentaram as decisões diante das quais eles sentem maior indignação por conta dos modos poucos democráticos como foram concebidas e executadas. Entre essas se destacaram: o fechamento da Casa da cultura em Varadero; o fechamento do Estaleiro de Cárdenas para mudá-lo para a cidade de Cienfuegos; as problemáticas associadas às moradias em Varadero e as estratégias para erradicar as ilegalidades nessa matéria, assim como, mais uma vez, a unificação 
dos municípios de Cárdenas e Varadero para conformar o único município de Cárdenas.

\subsection{Papel na supervisão da execução das decisões tomadas no território.}

Outro campo onde o OP e a AMPP têm influenciado em termos de democratização é a supervisão das decisões tomadas nos seus territórios, relacionadas fundamentalmente com serviços e obras. Em Porto Alegre os entrevistados destacaram vários procedimentos e/ou espaços que facilitam não só avaliar onde estão faltando e ou onde foram investidos certos recursos, como também acompanhar e fiscalizar a execução de determinada obra, tanto num bairro, quanto na cidade.

Além das PR e as Assembleias temáticas, considerados espaços importantes para contribuir com o processo em questão, foi reconhecida a importância dos Conselheiros como agentes primordiais na supervisão da execução das decisões tomadas no território. Segundo esses atores, eles ganham um Tablet cedido pelo governo para ser usado durante os seus mandatos. Através desse Tablet, que tem um chip com internet, eles conseguem ter acesso a OBSERVAPOA, que oferece todo o status de acompanhamento das demandas feitas em cada região e que constam no plano de investimento. Ou seja, eles conseguem saber por cada região em que fase estão as obras, os serviços e se a realização dos projetos foi concluída.

Outros procedimentos ressaltados para facilitar a supervisão e/ou fiscalização da execução de decisões foram o PI (citado em seções anteriores) e as diferentes Comissões: Comissões de obras, Comissões de Educação, de Saúde, etc ${ }^{99}$. Essas Comissões são criadas em cada região segundo suas necessidades e são compostas

\footnotetext{
${ }^{99}$ A partir de uma planilha com a descrição da obra, a comissão fiscaliza a execução das obras que foram aprovadas em certas regiões. Alguns entrevistados expressaram que é raro que se faça essa fiscalização em certas regiões. Mas, de qualquer forma, é um mecanismo que está dentro da concepção do OP e segundo o RI a população tem autonomia para fazer essas Comissões e fiscalizar as obras mediante as mesmas.
} 
por um membro da prefeitura e por membros das comunidades: Conselheiros, presidentes de associações, etc., com respaldo governamental e normativo (segundo os entrevistados existem decretos do governo autorizando e institucionalizando a criação das mesmas). Do mesmo modo, as citadas Comissões têm poder para interromper as obras frente a qualquer irregularidade ou contradição com o projeto original que foi aprovado nas regiões (seja em termos de recursos, de formas de fazer, estrutura, etc.).

No município existem comissões compostas por pessoas das comunidades, que tem o dever de fiscalizar a execução de determinadas obras. Ou seja, tem a missão de fiscalizar se está sendo feito aquilo que foi dito ou decidido para fazer. Por exemplo, foi decidido fazer uma escola com dois andares? Por que então nesta fundação cabe só um andar? As comunidades têm capacidades para reclamar dos atores correspondentes que a obra está sendo feita de uma forma ou de outra, em contradição com o que foi definido. Inclusive existem as Comissões de obras que a gente monta nas comunidades. Já aqui houve obras que foram paradas porque não estavam sendo bem-feitas ${ }^{100}$.

Em correspondência com essas capacidades que a maioria dos atores entrevistados reconheceram no OP, alguns exemplos ilustrativos foram apontados, como as decisões relacionadas à Caixa Econômica Federal sobre as obras de habitação, a construção de uma escola na região Nordeste e a construção de uma obra de esgoto na região Norte.

Em relação à Caixa Econômica Federal, o OP definiu junto com o governo o acompanhamento da construção de prédios com probabilidades de serem entregues no final do ano. A construção da obra foi paralisada por petição de um dos moradores que fazia parte da Comissão de obras.

Fato semelhante aconteceu com a construção da escola na região Nordeste, que foi paralisada quando um habitante aposentado, membro da Comissão, percebeu irregularidades na obra que contradiziam o projeto inicial. A obra de esgoto, por sua

\footnotetext{
${ }^{100}$ Falas de Gestores, Conselheiros, Vice-prefeitos em Porto Alegre.
} 
vez, foi reiniciada por conta das reclamações de um dos Conselheiros da Comissão de obras:

(...) há pouco estava sendo construída uma escola aqui perto. E um habitante (...) deu conta que no projeto estava definido que tinham que fazer uns buracos de $11,5 \mathrm{~m}$ de profundidade para a base do prédio. A empresa tinha feito os buracos de 4,5 m. Aí ele registrou isso, veio um engenheiro, confirmaram a situação e a obra foi reiniciada. Por exemplo, aqui na minha rua, foi trocado o esgoto, que era esgoto único para fazer dois: cloacal e pluvial. Isso foi pedido pelo OP. Então fizeram a troca, votaram uns paralelepípedos, mas (...) ficou regular. Eu que estava fiscalizando fui lá à empresa, reclamei, eles tiraram e agora estão fazendo a obra novamente ${ }^{101}$.

Paralelamente à supervisão das Comissões, constatada através das falas dos entrevistados, percebeu-se que em Porto Alegre ainda existem atores locais que advertem certas insuficiências no sentido até aqui descrito. Alguns dos entrevistados expressaram que a fiscalização por mediação das mencionadas Comissões não têm sido frequentes nos últimos dois governos. Além disso, apontaram ainda que as Comissões não são uma realidade generalizada em todas as Regiões, apesar da importância de terem um apoio institucional.

Houve um tempo que dentro das regiões existiam as Comissões de obras. Elas eram criadas para fazer isso. Mas já não, quase ninguém faz as comissões nos seus territórios. (...) isso funcionou no início do OP. Depois que assumiu estes últimos dos governos, isso não tem acontecido mais. Tudo bem, nem todas as regiões tem essas comissões. Mas é uma coisa que pode ser feita, além de que outras sim têm. Isso é raro acontecer, quase nenhuma região fiscaliza as obras, algo que hoje é uma falha do $\mathrm{OP}^{102}$.

No caso de Cárdenas, esse processo de supervisão das decisões por parte da população tem se mostrado de forma mais favorável. Do ponto de vista normativo, o funcionamento da AMPP favorece que a população supervise a execução das

\footnotetext{
${ }^{101}$ Fala de um dos Conselheiros.

${ }^{102}$ Fala de Delegados, alguns Conselheiros e habitantes em Porto Alegre.
} 
decisões tomadas no território através de ferramentas como o Dc, os Pcp, as Comissões de Trabalho, as Rc e as SeAMPP ${ }^{103}$.

No caso dos Dc, existe um conjunto de diligências que necessariamente os convertem em atores responsabilizados por representar a população. Entre essas se encontram: o fato de participar com voz e votos nas SeAMPP e nas Comissões de Trabalho; seu dever de procurar soluções sobre os problemas da população baseados nas análises conjuntas sobre a realidade; e seu dever de passar as opiniões e necessidades dos seus eleitores para o governo, assim como de passar as informações sobre a gestão governamental para seus eleitores (ANPP, 1995, 1999, 2010). Esse conjunto de funções concedidas aos Dc exige a necessária supervisão das decisões executadas nos seus territórios, a fim de poder socializar as informações sobre a realidade:

\begin{abstract}
"Los delegados a las Asambleas Municipales del Poder Popular tienen los derechos y las obligaciones que les atribuyan la Constitución y las leyes y en especial están obligados a: a) dar a conocer a la Asamblea y a la Administración de la localidad las opiniones, necesidades y dificultades que les trasmitan sus electores; b) Informar a sus electores sobre la política que sigue la Asamblea y las medidas adoptadas para la solución de necesidades planteadas por la población o las dificultades que se presentan para resolverlas; c) rendir cuenta periódicamente a sus electores de su gestión personal, e informar a la Asamblea o a la Comisión a la que pertenezcan, sobre el cumplimiento de las tareas que les hayan sido encomendadas, cuando éstas lo reclamen (ANPP, 1995, 2010)".
\end{abstract}

De igual modo, sobre as funções dos Pcp se estabelece o dever de controlar, fiscalizar e exigir a participação ativa do povo, bem como o estrito cumprimento do estabelecido quanto à qualidade dos serviços à população. Para isso, o conjunto de direções administrativas, empresas, unidades de serviços e entidades produtivas, além informar aos Pcp e Dc sobre as questões relacionadas com os assuntos públicos que afetam os interesses da população, também devem criar condições organizativas

\footnotetext{
${ }^{103}$ Sobre as Rc e as SeAMPP, já se declarou indiretamente suas capacidades para facilitar a supervisão das decisões tomadas no território, por constituírem os principais espaços onde se executam debates sobre a realidade social. Não obstante, para maior informação ao respeito, ver $\operatorname{ANPP}(1995,1999)$.
} 
necessárias para facilitar contatos com esses atores, a fim de analisar os assuntos pertinentes. Somado a essas funções, os Pcp também têm poder para propor mudanças na direção das entidades municipais e se dirigir ao presidente da AMPP, da APPP, assim como ao Presidente do Conselho de Estado, no caso de não obter resposta diante das suas solicitações (ANPP, 2000). Sobre essas capacidades, tratam as seguintes citações:

\begin{abstract}
“(...) exigir eficiencia en el desarrollo de las actividades de producción y de servicios a las entidades enclavadas en su área de acción y apoyar, en lo posible, su realización; "controlar y fiscalizar las actividades de las entidades existentes en la demarcación, independientemente de su nivel de subordinación;" "promover la participación de la población, de las instituciones y entidades de la demarcación para desarrollar iniciativas que contribuyan a lograr el mayor avance en las tareas que se propongan, así como cohesionar el esfuerzo de todos"; "Cuando el Presidente del Consejo Popular, en virtud de planteamientos respecto a situaciones que afecten los intereses de la comunidad, haya realizado en sus gestiones todos los trámites posibles en el Municipio, sin obtener respuesta o la que reciba no resulte convincente, de estimarlo necesario, puede dirigirse sucesivamente al Presidente de la Asamblea Provincial, al Presidente de la Asamblea Nacional y al Presidente del Consejo de Estado, para informarle de la situación existente, las gestiones realizadas y las consideraciones que tiene sobre el asunto en particular, a los efectos que procedan". (ANPP, 2000) ${ }^{104}$.
\end{abstract}

As Comissões de Trabalho também se destacam como ferramenta que facilita a fiscalização por parte do povo sobre a execução das decisões. Elas são formadas por Dc eleitos pela população e entre suas funções está a realização de visitas e a sustentação de vínculos de trabalho com os $\mathrm{CP}$, com a finalidade de comprovar o cumprimento do estabelecido na Constituição e nas Leis, assim como para conhecer os critérios dos cidadãos sobre assuntos de seu interesse:

"Las Comisiones de Trabajo de las Asambleas Nacional, Provinciales y Municipales del Poder Popular efectúan visitas y sostienen vínculos de trabajo con los Consejos Populares para contribuir a su funcionamiento y comprobar el cumplimiento de lo establecido en la Constitución y las leyes, e informarse de su labor, conocer los criterios

\footnotetext{
${ }^{104}$ Capítulos III e XI, Artículo 21 (incisos d, f e g) e Artículo 63 respectivamente.
} 
sobre asuntos de interés y lograr su participación en actividades que desarrollan (ANPP, 2000, art. 61)”.

Apesar da existência dessa estrutura participativa que prevê as capacidades antes mencionadas, do ponto de vista prático se visualiza uma realidade diferente. Nesse sentido, os atores entrevistados reconheceram uma discrepância entre o que se diz (se referindo aos discursos oficiais e normativos) e o que se faz na realidade. Para Dc, Pcp e habitantes em geral, esses processos de supervisão se materializam muito pouco principalmente por conta do papel passivo que do ponto de vista prático e subjetivo é atribuído aos DC e Pcp, principais atores encarregados dessa tarefa:

Por el poco papel que se le dado al delegado no se hace, pero según esta establecido debe hacerse. Las decisiones vienen preconcebidas por las direcciones de la asamblea municipal o provincial y el delegado como la población no tienen disposición sobre ellas. La supervisión es más bien parcial, porque generalmente es una cosa lo que se dice y otra lo que se hace en la realidad.

No caso dos Dc e Pcp, essas funções estão relacionadas com a transmissão de informação do governo para a população e vice-versa, assim como com a fiscalização de estratégias executadas e de instâncias que ofereçam serviços no território. No entanto, essas funções, que tem um caráter passivo em termos de tomada de decisões, prejudicam a legitimidade desses atores para fiscalizar certos organismos, como hospitais, empresas como as de produção de pão ${ }^{105}$, mercados agropecuários, etc.

\footnotetext{
${ }^{105}$ Um exemplo disso foi a experiência vivida por um dos Dc. Esse sujeito denunciou uma situação prejudicial para a população na empresa produtora de pão do seu bairro. A empresa produz certa quantidade de pão que não satisfaz à população, entre outros fatores, por conta de que os "trabajadores por cuenta propia" (setor privado que oferece serviços de gastronomia) compram todos os pães para depois serem revendidos nos seus comércios. O governo não havia criado uma empresa para satisfazer as demandas desse setor. Dias depois da sua denúncia, sua casa foi atacada com uma pedra enquanto ele dormia, atingindo o interior da mesma. Perante essa situação, não houve manifestação alguma por parte das autoridades municipais: governo, policiais.
} 
Dessa forma, partindo das experiências narradas pelos entrevistados, se percebe que acompanhar a execução das decisões é um fator que facilita o controle das decisões tomadas, mas que esse acompanhamento ainda possui limitações. Essa supervisão deve estar acompanhada de competências para que a população possa influenciar na retificação das decisões e/ou estratégias, o que acontece simplesmente em decisões associadas a alguns serviços e de forma relativamente extraordinária.

A partir dos diferentes elementos apresentados, pode-se constatar que existem várias similaridades entre o OP e a AMPP no que se refere às capacidades que estas instâncias fornecem para que a população controle tanto os atores governamentais quanto as decisões sobre os assuntos públicos. Essas similaridades consistem em aspectos tanto favoráveis quanto desfavoráveis, relativos ao processo que se examina.

Como características favoráveis no que concerne ao controle dos atores governamentais, se destaca que o OP e AMPP constituem espaços de certo empoderamento dos cidadãos, possibilitando diálogos diretos entre sociedade civil e governo. Esses diálogos simultaneamente disponibilizam oportunidades para que a população seja informada sobre a gestão governamental e suas justificativas, bem como permite a avaliação da gestão. Por último, ressalta-se que através de ambos os mecanismos a população adquire determinadas capacidades para controlar os atores governamentais do ponto de vista político.

De outro lado, como características desfavoráveis, deve-se mencionar que, mesmo sendo o OP e a AMPP espaços de empoderamento dos cidadãos que promovem diálogos diretos entre governantes e governados, foi comum o reconhecimento da necessidade de aprimoramento em vários sentidos. Assim, ressaltou-se a necessidade de divulgação dessas ferramentas democráticas, com a finalidade de garantir uma maior socialização de informações, bem como a incorporação de uma maior porcentagem da população, com o propósito de aumentar as capacidades dos cidadãos para exercer um controle mais integral dos atores políticos. 
Junto com essas limitações, destacam-se igualmente mais duas semelhanças. A primeira é a existência de algumas restrições nas capacidades de sanção sobre os atores políticos por parte da população. A segunda é o conjunto de insatisfações que alguns atores mostraram em relação ao papel dos representantes populares na socialização de informações.

Perante os elementos exibidos relativos às capacidades que o OP e a AMPP proveem para que a população controle as decisões, pode-se verificar que existem várias analogias entre dos dois mecanismos, apesar das suas diferenças. Essas analogias, assim como no eixo anteriormente analisado, envolvem aspectos positivos e negativos.

Como aspecto positivo, o OP e AMPP (através das Rc e das SeAMPP) facilitam à população algumas capacidades para incidir na definição das políticas públicas, sobretudo, ligadas ao âmbito comunitário e mais imediato. As formas mediante as quais se materializam essas capacidades consistem no papel de determinadas Comissões (tem missão de avaliar a realidade e discutir com o governo), assim como nas funções de diferentes representantes populares eleitos pelos próprios cidadãos. Entre essas funções dos representantes se ressaltam, particularmente, o fato de que eles devem apresentar e debater as inquietudes dos seus eleitores com o governo.

Em relação aos aspectos negativos dos processos de controle das decisões por parte da população, há também elementos comuns entre os dois mecanismos. Observam-se, nesse sentido, as limitações da população para incidir no desenho estratégico e mais amplo da cidade, assim como a escassez de recursos financeiros existentes, que constituem importantes limitações para que tanto o OP quanto a AMPP viabilizem um maior impacto dos cidadãos na definição das políticas públicas.

Como resultado das mencionadas restrições, consequentemente se percebe que ambas as experiências padecem de incredibilidade como mecanismos 
democráticos por parte de certa fração da população (Delegados, habitantes). Esse fato deriva no reconhecimento de melhorar a definição e a execução democrática das políticas públicas a partir dos mecanismos analisados.

Outro aspecto positivo presente tanto no OP quanto na AMPP se encontra no âmbito das suas contribuições para informar e debater (refutar ou aceitar) as decisões a serem executadas. Nesse sentido, se observou que através dos dois procedimentos a população se mantém informada sobre decisões relativas aos assuntos públicos, derivando em capacidades para que as mesmas sejam debatidas.

Não obstante, e como bem será tratado na seção a seguir, ainda existem restrições na promulgação de debates para refutar ou aceitar as decisões a serem executadas. Esse fato faz com que tanto em Cárdenas quanto em Porto Alegre a maioria dos atores não reconheçam competências para rejeitar decisões sobre questões “macro". Por último, se observou, ainda, que o OP e AMPP facilitam aos cidadãos capacidades para supervisionar a execução das decisões tomadas no território, sem deixar de reconhecer certas restrições nesse processo. 


\section{OP E A AMPP. REFLEXÕES COMPARATIVAS SOBRE CAPACIDADES DE DEMOCRATIZAÇÃO}

Depois de ter apresentado as principais semelhanças e diferenças entre o OP e a AMPP, relativas às capacidades que disponibilizam aos cidadãos para que incidam em diferentes processos da democratização, se faz necessário prosseguir com outra fase analítica. Desenvolve-se, a seguir, de modo mais profundo, uma série de reflexões conclusivas entorno das implicações dessas ferramentas no processo analisado que, com fins basicamente didáticos, parte do necessário resgate das principais semelhanças que foram apontadas.

As reflexões comparativas que ora faremos se baseiam nos vários eixos analíticos vinculados às duas dimensões que sustentam o desenvolvimento dessa pesquisa, coadunando com o objetivo geral do presente estudo: comparar $o$ funcionamento do "OP" em Porto Alegre e da "AMPP" em Cárdenas, sobre a base das suas atuais contribuições para a democratização das decisões sobre os assuntos públicos.

O primeiro eixo diz respeito ao papel do OP e da AMPP na geração de capacidades para que diferentes atores locais incidam na configuração das condições que sustentam os processos decisórios. Nesse processo, se constataram algumas similitudes, apesar dos diferentes contextos (políticos, sociais, culturais, etc.) nos quais elas se desenvolvem.

As capacidades oferecidas à população para estabelecer mecanismos que fortaleçam os debates públicos e a tomada de decisões constituem uma das áreas onde se refletem as similitudes constatadas. Dependendo dos atores a considerar, até o momento das entrevistas nenhuma das duas ferramentas se configurou como agente ativo na promulgação de debates referentes ao estabelecimento de mecanismos alternativos aos existentes. 
No caso da experiência em Porto Alegre, a maioria dos entrevistados expressou que se tem debatido o aprimoramento do $\mathrm{OP}$, enquanto que outra parte dos próprios entrevistados ${ }^{106}$ declarou ter existido debates sobre mecanismos alternativos, apesar de que sua materialização empírica tenha sido cortada por falta de apoio do governo e do próprio OP. No caso de Cárdenas, não se constataram debates, nem mesmo ao nível de criação de mecanismos complementares à AMPP. No entanto, as instâncias analisadas apresentam similitudes ao se considerar que, embora com graus diferentes, ambas as experiências investigadas conseguem de algum modo retalhar tentativas espontâneas de estabelecimento de mecanismos alternativos. Este movimento tende à monopolização dos processos democráticos ${ }^{107}$, apesar das comuns limitações dessas ferramentas em termos de democratização das decisões sobre os assuntos públicos:

O que tem que existir é só o OP. Ele não considera, autoriza e concorda com outros mecanismos. Ou seja, é o OP e pronto. Essas propostas não tiveram o suficiente apoio do OP nem do governo. Tanto assim que o OP não é hoje um mecanismo da prefeitura dentro da comunidade para conversar, negociar com a comunidade. Ultimamente ele está sendo mais um trabalho remunerado, eles ganhando um dinheiro para se relacionar com a gente. Não é uma coisa que seja obrigação pela comunidade. Eles estão sendo pagos para ouvir a comunidade e, portanto, a situação não vai além. Nunca he escuchado que se haya debatido sobre la implementación de otros mecanismos ni nada por el estilo. Además eso es por gusto, porque aunque se discutiera, el gobierno no le iba a dar alas. No, porque esos mecanismos ya existen y son los que el gobierno ha creado ${ }^{108}$.

Entre os motivos que explicam como tais tentativas de debates acontecem, também se percebem aspectos comuns, apesar das diferenças. Em Porto Alegre, entre alguns atores (gestores, vice-prefeitos e vários conselheiros) essa situação se deve ao fato do OP ser um mecanismo através do qual se debate a maioria das decisões, tornando-se desnecessária a execução de outros mecanismos. Em

\footnotetext{
${ }^{106}$ Essa população tem rasgos similares àquela que em Cárdenas expressaram as mesmas limitações sobre AMPP. Especialmente se caracteriza por ter cenários de socialização mais relacionados com o povo do que com o governo: Delegados, habitantes e alguns Conselheiros.

$107 \mathrm{O}$ governo tem apoiado outros mecanismos ou programas como a Governança Local. Mas o mesmo não é reconhecido como exitoso em todos os setores da população, além de ter sido impulsionado pela própria prefeitura.

${ }^{108}$ Fundamentalmente essas citações se referem às falas de Delegados e habitantes em Porto Alegre.
} 
Cárdenas, a mencionada ausência se deve essencialmente a duas ideias, de acordo com depoimento da maioria dos entrevistados: 1- A população considera impossível que novos mecanismos possam ser materializados; 2- Do ponto de vista normativo, não há necessidade de novos mecanismos, uma vez que eles são criados para favorecer o processo mencionado.

Outro elemento comum entre ambas as experiências é a necessidade de aprimoramento $^{109}$. Tanto em Cárdenas quanto em Porto Alegre, as opiniões sobre como executar melhorias estiveram divididas: enquanto alguns advogavam por criar mecanismos alternativos, outros defendem a criação de mecanismos complementares. Uma representação gráfica das semelhanças até aqui identificadas, constitui o seguinte Quadro:

\section{Quadro 3 - Condições que sustentam os processos decisórios}

\begin{tabular}{|c|c|c|c|}
\hline \multicolumn{2}{|c|}{ Semelhanças OP e AMPP } & \multicolumn{2}{|r|}{ Diferenças OP e AMPP } \\
\hline \multirow{2}{*}{\multicolumn{2}{|c|}{$\begin{array}{l}\text { Reconhecimento de ausência de } \\
\text { debates sobre procedimentos } \\
\text { alternativos. }\end{array}$}} & $\int \mathrm{OP}$ & $\begin{array}{l}\text { - Geralmente todos os atores (Delegados, } \\
\text { habitantes, certos Conselheiros, Gestores } \\
\text { CARs, vice-prefeitos). }\end{array}$ \\
\hline & & AMPP & $\begin{array}{l}\text { - Alguns atores (Delegados, habitantes, e } \\
\text { Conselheiros). }\end{array}$ \\
\hline \multirow{2}{*}{\multicolumn{2}{|c|}{$\begin{array}{l}\text { Reconhece-se a ausência de debates } \\
\text { sobre outros mecanismos se sustenta } \\
\text { em que é desnecessário }\end{array}$}} & \multirow{2}{*}{$\begin{array}{c}\text { OP } \\
\text { AMPP }\end{array}$} & • Por assuntos práticos. \\
\hline & & & $\begin{array}{l}\text { - Desnecessário por assuntos normativos. } \\
\text { - Impossibilidade de materialização. }\end{array}$ \\
\hline \multirow{2}{*}{\multicolumn{2}{|c|}{$\begin{array}{l}\text { Retaliação de tentativas espontâneas } \\
\text { de estabelecimento de mecanismos } \\
\text { alternativos. Tendência à } \\
\text { monopolização dos processos } \\
\text { democráticos }\end{array}$}} & \multirow{2}{*}{$\begin{array}{c}\text { OP } \\
\text { AMPP }\end{array}$} & $\begin{array}{l}\text { - Alguns atores em Porto Alegre (Delegados, } \\
\text { habitantes). }\end{array}$ \\
\hline & & & • Nenhum dos atores em Cárdenas. \\
\hline \multicolumn{4}{|c|}{$\begin{array}{r}\text { Existência de debates em Porto Alegre sobre estabelecimento de mecanismos complementares, } \\
\text { enquanto que em Cárdenas, não foi declarado. }\end{array}$} \\
\hline \multicolumn{4}{|c|}{ Reconhecimento entre alguns atores da necessidade de criar outros mecanismos. } \\
\hline $\begin{array}{l}\text { Reconhecimento de } \\
\text { melhoras a partir de vários } \\
\text { fatores }\end{array}$ & OP & \multicolumn{2}{|c|}{$\begin{array}{l}\text { - Debates que transcenda questão orçamentária. } \\
\text { - Relações entre Prefeitura e OP na gestão dos assuntos } \\
\text { públicos. Socialização. Incorporação de mais atores. }\end{array}$} \\
\hline \multicolumn{4}{|c|}{$\begin{array}{l}\text { Apesar dessa similitude, as áreas onde o OP e AMPP devem melhorar resultam diferentes. Por um } \\
\text { lado: Debates que transcenda questão orçamentária; Relações entre Prefeitura e OP na gestão dos } \\
\text { assuntos públicos; Socialização e Incorporação de mais atores. Por outro: Erradicação de debates sem } \\
\text { efeitos práticos na gestão governamental e Papel desses instrumentos numa maior democratização da } \\
\text { gestão dos assuntos públicos. }\end{array}$} \\
\hline
\end{tabular}




$\left\{\begin{array}{lll}\text { AMPP } & \begin{array}{l}\text { Erradicação de debates sem efeitos práticos na } \\ \text { gestão governamental. } \\ \bullet \text { Papel desses instrumentos numa maior } \\ \text { democratização da gestão dos assuntos públicos. }\end{array} \\ \hline\end{array}\right.$

Fonte: Pesquisa de campo, 2015/2016.

No que diz respeito às capacidades do OP e da AMPP para impulsionar discussões nas quais a população possa aceitar ou refutar regras a serem estabelecidas para a tomada de decisões, também se percebem semelhanças. A primeira delas traz as diferenças que caracterizam as duas experiências e pode ser apreciada nas falas dos agentes locais, em maioria vinculada à sociedade civil: habitantes e Delegados do OP e da AMPP respectivamente.

Para ambos os grupos, as ferramentas democráticas analisadas não constituem uma distribuição equitativa de poder entre o Estado e sociedade civil, diante da definição do marco normativo da tomada de decisões. No caso de Porto Alegre, alguns atores (vice-prefeitos, gestores e certos conselheiros) expressaram valorações favoráveis e críticas moderadas, ao contrário de outros sujeitos que argumentaram críticas mais radicais neste processo valorativo: habitantes e Delegados.

Com base nessas críticas mais impetuosas, o governo de Porto Alegre possibilita capacidades para que a população incida na definição de regras que sustentam a tomada de decisões, mas apenas sobre assuntos considerados "paliativos" das falhas do sistema social em geral: construção de escolas, creches, postos de saúde, pavimentação, esgotos, rotas de transporte, entre outros. No caso de Cárdenas, as regras para a tomada de decisões que nos marcos da AMPP podem ser influenciadas pela população, não se referem aos mesmos assuntos que em Porto Alegre (o sistema político e social cubano tem demonstrado ser mais eficiente para garantir muitos desses serviços). Não obstante, também podem ser classificadas de atenuantes, porquanto são centradas em problemáticas como: iluminação nos bairros, estado higiênico sanitário das instituições de saúde pública (Hospitais, policlínicos), déficit de pessoal especializado no setor da educação, indisciplinas sociais, problemáticas da estrutura das vias na cidade (limpeza, roturas), etc. 
Portanto, considerando essas limitações comuns, pode-se entender que diante de ambas as experiências, os governos ainda mantêm seu domínio sobre as lógicas que definem a tomada de decisões sobre aqueles assuntos públicos centrais, que constituem as principais determinantes das limitações e demandas populares em Cárdenas e Porto Alegre. Dessa forma, a população consegue influenciar apenas nas normativas da tomada de decisões relativas aos assuntos (econômicos, culturais, sociais, políticos) que derivam do modo como se configuram os campos do poder estatal sobre as políticas. Como consequência desse processo, os governos camuflam sua autonomia e disfarçam a incapacidade da população para influenciar as normativas que regem a tomada de decisões sobre assuntos medulares que afetam a população. Esse processo decisório sobre assuntos medulares deveria estar marcado por uma melhor distribuição do poder, como condição essencial da democracia.

Entre esses assuntos medulares, podem-se destacar no caso de Porto Alegre algumas políticas sobre: o pagamento diferenciado dos impostos; as formas de distribuição do pressuposto do município; as políticas de seguranças e de acesso aos serviços públicos (saúde, educação e cultura). Para o caso de Cárdenas é possível incluir: divisão política-administrativa e suas implicações sociais; relação salários e custos de serviços, como transporte, energia, alimentação; controle coativo sobre o governo e as instituições de prestação de serviços públicos (saúde, energia, jurídicos, entre outros). O quadro a seguir mostra uma síntese das semelhanças e diferenças em torno da questão:

Quadro 4 - Regras para a tomada de decisões

\begin{tabular}{|c|c|c|}
\hline \multirow{3}{*}{$\begin{array}{c}\text { Semelhanças OP e AMPP } \\
\text { Negação dos mecanismos como } \\
\text { ferramenta para empoderar cidadãos } \\
\text { diante da configuração normativa de } \\
\text { processos decisórios sobre temas } \\
\text { profundos. }\end{array}$} & \multicolumn{2}{|r|}{ Diferenças OP e AMPP } \\
\hline & & $\begin{array}{l}\text { - Alguns atores (Delegados, habitantes e } \\
\text { certos Conselheiros). }\end{array}$ \\
\hline & & $\begin{array}{l}\text { - Alguns atores (habitantes e certos } \\
\text { Delegados). }\end{array}$ \\
\hline \multirow{2}{*}{$\begin{array}{l}\text { Incidência em marco normativo de } \\
\text { processos decisórios sobre assuntos } \\
\text { paliativos. }\end{array}$} & & - Maioria dos atores em Porto Alegre \\
\hline & AMPP & $\begin{array}{l}\text { - Alguns atores: habitantes e certos } \\
\text { Delegados. }\end{array}$ \\
\hline \multicolumn{3}{|c|}{$\begin{array}{l}\text { Incidência em marco normativo de processos decisórios sobre assuntos que não representam } \\
\text { distribuição de poder do Estado, segundo delegados, habitantes e especialistas. }\end{array}$} \\
\hline
\end{tabular}


Reconhecimento de melhoras.

Fonte: Pesquisa de campo, 2015/2016.

Apesar das semelhanças observadas, em outro aspecto vinculado ao eixo em questão, se identificam mais diferenças que semelhanças. Trata-se da oportunidade do OP e da AMPP de facilitar a influência da população nos modos de definir a agenda que orienta os debates públicos, assim como a supervisão dessa definição.

Em Porto Alegre se constatam melhores condições para que a população defina as condições sobre as quais será formada a agenda de debates, enquanto que, em Cárdenas, não tem existido experiências dessa natureza. O motivo dessa inexistência está no fato de o governo ser responsável pela configuração dessas normativas, além da elaboração da agenda pública.

De igual maneira, em relação às capacidades para supervisionar a definição da agenda de debates, na prática, o OP apresenta melhores resultados, o que se dá pelo papel que cumprem nesse processo não só os diferentes espaços de debates dentro do ciclo do OP junto com os Delegados e Conselheiros, como também pela função do conhecido PI. Essa situação se visualiza de forma limitada na experiência da AMPP em Cárdenas, mesmo que, do ponto de vista normativo, existam diferentes mecanismos para acompanhar o desempenho dos diversos assuntos públicos no município. Entre esses se destacam o papel dos Dc, das Rc e das SeAMPP.

Um segundo eixo analítico a ser desenvolvido, versa sobre o papel do OP e da AMPP na geração de capacidades para o controle dos atores políticos, em particular a população, nos seus respectivos territórios municipais. Nos dois pontos explorados nesta dimensão de análise, constataram-se também diversas semelhanças entre as experiências de Porto Alegre e de Cárdenas.

O primeiro dos pontos semelhantes são as capacidades do OP e da AMPP de facilitar o acesso à informação sobre a gestão dos atores políticos e suas justificativas, o que possibilita melhores acompanhamento e avaliação da gestão. 
Nas duas experiências existem formas estabelecidas para propiciar a difusão de informações sobre a gestão governamental, especificamente relacionada às demandas púbicas. Essas formas consistem no papel de determinados atores e nas concepções de diferentes espaços. No caso de OP se destacam o papel dos Delegados, Conselheiros do OP, assim como as funções dos FROP, do COP e do PI, além da estratégia OBSERVAPOA. No caso da AMPP sobressaem o papel dos Delegados e Presidentes dos Conselhos Populares, além das Rc e as SeAMPP.

Referente aos atores, destaca-se nas duas experiências competências para estabelecer relações com o governo, evidenciando a necessidade de receberem informações que posteriormente deverão ser repassadas para a população. Essas relações se materializam não só em reuniões específicas onde os representantes dos cidadãos podem e devem participar, mas também em despachos diretos que esses representantes têm direito de solicitar para os governantes.

Os espaços, por sua vez, favorecem o acesso às informações sobre a gestão do governo, pois foram criados e executados como mecanismos profundamente voltados para esse processo. Além disso, contribuem para favorecer que a população avalie a gestão governamental sobre os assuntos públicos.

Um dos aspectos que facilitam a informações e a avaliação por parte dos cidadãos é a participação que deve existir dos atores do governo nesses espaços, prestando contas da sua gestão e mostrando as justificativas para suas ações. No entanto, partindo das falas dos cidadãos entrevistados, se constata que, na prática, o OP tem tido melhores resultados em relação a esse processo, pois as informações nesse contexto têm um caráter mais amplo: se informa sobre ações e atitudes do governo, as decisões tomadas, as grandes normativas e a forma como são executadas, entre outros temas.

O outro aspecto comum entre o OP e a AMPP é a necessidade de aprimorar esses mecanismos em função da socialização de informações, uma vez que o aprimoramento se baseia no imperativo de dar maior divulgação para essas 
ferramentas. Em Porto Alegre, o imperativo anterior é evocado porque a maioria da população participante no OP tem maior desvantagem socioeconômica. Em Cárdenas, por sua vez, nas SeAMPP geralmente participam os Dc e demais diretivos do município. Dessa forma, a população em geral tem uma grande sub-representação nessas Sessões, fundamentalmente por causa da falta de divulgação e por conta da desmotivação da população em participar do mencionado procedimento, desestimulando a procura sobre as datas de realização das mesmas ${ }^{110}$.

Um último elemento comum dentro dessa segunda reflexão são as insatisfações percebidas nas falas de determinados atores no que se refere ao papel que, na prática, desenvolvem os representantes populares nos processos de socialização de informações. Em Porto Alegre, essa situação foi caracterizada através de certas falhas existentes na prática cotidiana de alguns desses representantes, especificamente entre os conselheiros. Em Cárdenas, a realidade descrita foi marcada pelo fato de que, em certas ocasiões, o governo não divulga informações específicas para os representantes do povo (Dc) ou simplesmente não informam os momentos oportunos, que correspondem com os interesses da população. O quadro 5 apresenta uma síntese das similitudes descritas em relação às capacidades de controle que os mecanismos analisados oferecem para os cidadãos:

Quadro 5 - Controle dos atores políticos (1)

\section{Semelhanças entre OP e AMPP}

Oportunidades para que a população seja informada sobre gestão governamental e suas justificativas (Delegados, Conselheiros, espaços).

Existência de oportunidades para que a população avalie a gestão governamental.

${ }^{110} \mathrm{Um}$ dos principais motivos dessa pouca motivação é o sentimento de cansaço e de frustração que alguns autores experimentam atualmente por considerar que os mecanismos como as Rc e as SeAMPP não constituem espaços eficientes de participação popular nas decisões no município. Para mais informação, ver Guach e Negri (2016). 
Necessidade de mais divulgação dos espaços, para favorecer maior socialização de informações.

Uma porcentagem mínima e específica da população é assídua aos espaços de socialização de informações ${ }^{111}$.

Certas insatisfações com o papel dos representantes populares na socialização de informações.

Fonte: Pesquisa de campo, 2015/2016.

No segundo ponto analisado no eixo relativo ao controle dos atores governamentais, que versa precisamente sobre as capacidades de sanção sobre os atores políticos, também se constataram tanto semelhanças e diferencias. Primeiramente, nenhuma das duas experiências tem capacidades para aplicar sanções do ponto e vista legislativo. No caso de Porto Alegre, especialmente, alguns atores expressaram não concordar com a possibilidade de que algum dia o OP tenha tais capacidades. Dessa forma, as capacidades de sanção se aplicam essencialmente do ponto de vista político e se materializam no poder dos cidadãos para promover a remoção dos atores governamentais dos seus cargos.

No caso do OP, essas capacidades se amparam nas cobranças que a população usualmente faz do governo, assim como nas tensões e pressões políticas que os cidadãos estabelecem diante de inconformidades relacionadas à gestão governamental. Nos marcos da AMPP, por sua vez, as mencionadas capacidades se baseiam no conjunto de normativas que outorgam à população poder para destituir seus representantes e governantes. Esses últimos, por meio dos seus representantes eleitos.

Ao mesmo tempo, como resultado dessas capacidades (outorgadas por vias diferentes) emergem os necessários diálogos diretos entre a sociedade civil e o governo, diante dos assuntos públicos. Sobretudo em Porto Alegre, esse diálogo foi

\footnotetext{
${ }^{111}$ Em Porto Alegre, segundo as falas de atores como Gestores dos CARs e Vice-prefeitos, a população que participa do OP oscila aproximadamente entre 1 e $2 \%$ da população. Em Cárdenas, não foi possível acessar as informações oficiais. Sem embargo, as três Rc e as duas SeAMPP que foram observadas pelo autor do presente trabalho no ano 2011, assim como a as duas Rc e a única SeAMPP onde se conseguiu participar no ano 2015, mostraram uma baixa porcentagem.
} 
colocado como um exemplo dos graus de empoderamento que a população tem adquirido durante o desenvolvimento do OP, em comparação com épocas anteriores onde era notável a separação entre ambos os estratos.

Apesar desses aspectos positivos em termos de capacidades de sanção que essas ferramentas possibilitam, os atores entrevistados expressaram argumentos críticos que têm pontos de contato. Verificaram-se nos dois casos investigados limitações para que os cidadãos exerçam "verdadeiras" sanções.

Essas limitações se apoiam em argumentos diferentes para ambos os casos. Em Porto Alegre, as limitações se baseiam nos constantes descumprimentos dos acordos estabelecidos entre a população, o OP e o governo, o que têm levado à quantidade de demandas não executadas mesmo depois de seus respectivos financiamentos terem sido aprovados. Para atores como Delegados do OP e habitantes em geral, os constantes descumprimentos constituem reflexos da incapacidade do OP para executar sanções em relação aos atores políticos.

Em Cárdenas, os argumentos se sustentam numa dimensão mais subjetiva que deriva sutilmente das falas dos entrevistados. Diante das distintas insatisfações que se tem mostrado em relação às capacidades democratizadoras da AMPP, a maioria dos sujeitos que ofereceram seus argumentos não se percebe como entes ativos na configuração da realidade política que deriva da gestão governamental (GUACH e NEGRI, 2016).

Esse modo de autopercepção dos sujeitos entrevistados mostra que os mecanismos em questão constituem um dever do governo, convertendo-se numa rotina através dos anos e perdendo seu caráter de direito dos cidadãos para exercer o controle coativo e as sanções políticas e morais pertinentes. Como resultado, eles não percebam como viável alguma possibilidade de exercer sanções como ocorre em Porto Alegre, mediante confrontos e cobranças exaltadas. 
O Quadro 6 sintetiza os últimos elementos descritos, relativos às capacidades de sanção sobre os atores políticos.

Quadro 6 - Controle dos atores políticos (2).

\begin{tabular}{|c|c|c|}
\hline Semelhanças OP e AMPP & & Diferenças OP e AMPP \\
\hline \multirow{2}{*}{$\begin{array}{l}\text { Graus de empoderamento que } \\
\text { facilitam diálogos diretos } \\
\text { entre sociedade e civil e } \\
\text { governo. }\end{array}$} & \multirow{2}{*}{$\begin{array}{c}\text { OP } \\
\text { AMPP }\end{array}$} & $\begin{array}{l}\text { - Mediante capacidades de sanção e coação da } \\
\text { população. }\end{array}$ \\
\hline & & - Mediante regras de funcionamento do governo. \\
\hline \multirow{2}{*}{$\begin{array}{l}\text { Capacidades de sanção } \\
\text { políticas consistem em } \\
\text { afastamento dos cargos do } \\
\text { governo. }\end{array}$} & $\mathrm{OP}$ & $\begin{array}{l}\text { - Mediante cobranças do povo e do } \\
\text { estabelecimento de tensões e pressões políticas. }\end{array}$ \\
\hline & - АMPP & $\begin{array}{l}\text { - Mediante normativas que regulam } \\
\text { funcionamento do governo (representantes } \\
\text { populares eleitos). }\end{array}$ \\
\hline \multirow{2}{*}{$\begin{array}{l}\text { Limitações nas capacidades } \\
\text { de sanção sobre os atores } \\
\text { políticos. }\end{array}$} & \multirow[t]{2}{*}{$\mathrm{OP}$} & 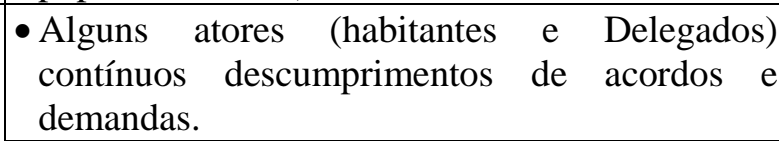 \\
\hline & & $\begin{array}{l}\text { - Formas de apropriação das Rc e das Se AMPP } \\
\text { como dever do governo e não como direito do } \\
\text { povo. }\end{array}$ \\
\hline
\end{tabular}

Fonte: Pesquisa de campo, 2015/2016.

O último eixo analítico concebido para desenvolver reflexões sobre o objeto de estudo do presente trabalho aborda o papel do OP e da AMPP na geração de capacidades para o controle das decisões sobre os assuntos públicos. Os três aspectos que foram tratados nesse eixo, assim como os anteriores, apresentam evidentes semelhanças, embora sejam variáveis as características que identificam o exercício das mencionadas capacidades entre os dois casos.

No primeiro desses aspectos, as capacidades que o OP a AMPP oferecem para que a população incida na definição das políticas públicas, evidenciou-se que as duas ferramentas oferecem certas capacidades no citado processo, mas com implicações e condicionamentos diferentes. Tanto em Cárdenas quanto em Porto Alegre existem, por exemplo, Comissões de trabalho integradas por lideranças populares que funcionam como mecanismo de análise da realidade social e de 
diálogo com o governo. Esse diálogo, em teoria, é o que facilitaria certo grau de incidência na definição de políticas públicas.

Não obstante, a partir de uma perspectiva prática, as ferramentas funcionam de forma diferente nas realidades pesquisadas. As Comissões que são criadas nos marcos do OP em Porto Alegre conseguem propiciar diálogos e debates entre a população e o governo, sobre as decisões e políticas a serem executadas. No caso de Cárdenas, essas Comissões são criadas nos marcos da AMPP e têm como algumas das suas principais funções procurar informações sobre temas específicos da realidade social e fiscalizar o funcionamento institucional, entre outros aspectos de tipo administrativos ${ }^{112}$.

Essas Comissões, junto com os diferentes espaços e mecanismos concebidos dentro do OP e da AMPP (FROP, COP e Rc e SeAMPP respectivamente), funcionam supostamente como estratégias por meio das quais a população coloca suas inquietudes e, dessa forma, influenciam nas políticas públicas. Sendo esse processo uma realidade mais notável na experiência em Porto Alegre.

A maior visibilidade da influência da população na definição das políticas publicas, mediante as inquietudes que conseguem colocar através do OP, se percebe

112 "La Asamblea Municipal del Poder Popular designa y denomina las comisiones permanentes de trabajo, por el término de duración de su mandato". "Para el ejercicio de sus funciones la Asamblea Municipal del Poder Popular se apoya en las comisiones de trabajo (...)". "Las comisiones de trabajo se forman por delegados de la propia Asamblea Municipal y están compuestas por un presidente, un vicepresidente, un secretario y un número determinado de miembros, designados por ella". "Las comisiones permanentes formadas por la Asamblea Municipal del Poder Popular, tienen las funciones siguientes: a) auxiliar a la Asamblea en la realización de sus actividades y especialmente en ejercer el control y la fiscalización de las entidades radicadas en su territorio; b) auxiliar a la Asamblea en el control del cumplimiento de las leyes y otras disposiciones legales vigentes por la entidades de subordinación municipal y por las de otros niveles de subordinación, que se encuentran radicadas en su territorio; c) obtener las informaciones que consideren necesarias de las empresas y unidades presupuestadas de subordinación municipal y de otros niveles de subordinación que radican en su territorio, y, a ese fín, podrán hacer fiscalizaciones directas, citar a sus funcionarios; d) realizar estudios y elaborar proyectos tendentes a lograr el perfeccionamiento de la producción y de los servicios, al mejor aprovechamiento de los recursos humanos, materiales y financieros, o acerca de la vida cultural, social y económica del territorio, los cuales someten a la consideración del presidente de la Asamblea Municipal y, de estimarlo éste necesario, a la propia Asamblea; e) emitir opiniones acerca de los informes que se rindan a la Asamblea; f) coadyuvar en el control del cumplimiento de las decisiones de la Asamblea y evaluar la eficacia de lo acordado. g) informar a la Asamblea de la labor que realiza, cuando ésta o su presidente lo estimen pertinente" (ANPP, 19955, artículos 4, 15 e 23). 
no âmbito das decisões governamentais. Em Porto Alegre, o OP consegue estabelecer certas tensões políticas que acabam facilitando a materialização de determinadas políticas, enquanto que, em Cárdenas, nem sempre os espaços e mecanismos mencionados têm implicado tensões que promovem essa materialização.

No entanto, as políticas que ambos os mecanismos conseguem influir são aquelas essencialmente ligadas ao âmbito comunitário e mais imediato. Entre essas se destacam: postos de saúde, creches, escolas, moradias, saneamento, esgotos. Em Porto Alegre elas são impulsionadas através das tensões estabelecidas pela população; em Cuba, são materializadas a partir da ênfase do Estado em garantir serviços básicos que em Porto Alegre resultam carentes. Neste caso se destacam, precisamente: postos de saúde, creches, escolas, moradias, saneamento, esgotos ${ }^{113}$.

Apesar das capacidades descritas, também foram identificadas limitações comuns nesse ponto. Tratam-se dos obstáculos que implicam os recursos financeiros para conseguir um maior impacto na configuração das políticas públicas, inclusive no próprio âmbito comunitário e mais imediato.

Vinculado a essas limitações, tanto o OP quanto a AMPP apresentam restrições para incidir na elaboração estratégica da cidade em termos de políticas públicas. As configurações e transformações mais importantes no âmbito social, político e econômico são aquelas que as ferramentas ainda não conseguem empoderar os cidadãos. Em Porto Alegre, por exemplo, questões como distribuição de oportunidades para o acesso a serviços fundamentais (educação, saúde, esporte, lazer), políticas de impostos, assim como o poder do "capital" na configuração da cidade e contra alguns interesses dos cidadãos, constituem os principais aspectos a considerar. Em Cárdenas, sobressaem as políticas de demolição de moradias, divisão política administrativa, situações adversas no pagamento da energia em Varadero associadas às políticas da vivenda, e outros.

\footnotetext{
${ }^{113}$ Em Cárdenas a questão do esgoto não está totalmente resolvida. Ainda existem bairros com problemas nesse sentido, segundo depoimento de alguns entrevistados.
} 
Como resultado dessas limitações comuns, derivam mais duas similitudes entre o OP e a AMPP. Nos dois casos, os Delegados e alguns habitantes mostraram sinais de incredibilidade em relação aos mecanismos democráticos analisados. E, com base nisso, visualiza-se um comum reconhecimento sobre a necessidade de melhorar na definição e execução democrática das políticas públicas, seguindo não só os discursos dos sujeitos mencionados, mas também a fala da maioria dos entrevistados.

O Quadro 7 sistematiza as informações oferecidas referentes aos mecanismos em questão e seus papeis na definição das políticas públicas.

\section{Quadro 7 - Definição das políticas públicas}

\begin{tabular}{|c|c|c|}
\hline $\begin{array}{l}\text { Semelhanças OP e } \\
\text { AMPP (Rc-SeAMPP) }\end{array}$ & & Diferenças OP e AMPP \\
\hline \multirow{2}{*}{$\begin{array}{l}\text { Comissões que tem missão } \\
\text { de discutir com o governo } \\
\text { sobre: }\end{array}$} & \multirow{2}{*}{$\begin{array}{c}\text { OP } \\
\text { AMPP }\end{array}$} & • Decisões ou políticas a serem executadas. \\
\hline & & $\begin{array}{l}\text { - Realidade social em geral; funcionamento } \\
\text { institucional }{ }^{114} \text {. }\end{array}$ \\
\hline \multirow{2}{*}{$\begin{array}{l}\text { Representantes apresentam } \\
\text { inquietudes da população } \\
\text { que influem nas políticas }\end{array}$} & \multirow[t]{2}{*}{ OP } & $\begin{array}{l}\text { - Acabam tencionando algumas pautas para que sejam } \\
\text { materializadas nas políticas públicas. }\end{array}$ \\
\hline & & $\begin{array}{l}\text { - Nem sempre tencionam pautas para que sejam } \\
\text { materializadas nas políticas públicas. }\end{array}$ \\
\hline \multirow{2}{*}{$\begin{array}{l}\text { Capacidades de definição } \\
\text { de políticas públicas, } \\
\text { ligadas ao âmbito } \\
\text { comunitário e mediato. }\end{array}$} & \multirow{2}{*}{$\begin{array}{c}\text { OP } \\
\text { AMPP }\end{array}$} & - Postos de saúde, creches, escolas, moradias, esgotos, etc. \\
\hline & & $\begin{array}{l}\text { - Saneamento, qualidade e manutenção dos serviços: } \\
\text { saúde (Hospital), escolas, esgotos. }\end{array}$ \\
\hline \multirow{2}{*}{$\begin{array}{l}\text { Os recursos constituem } \\
\text { limitações para um maior } \\
\text { impacto do OP e da AMPP } \\
\text { nas políticas públicas }\end{array}$} & \multirow[t]{2}{*}{$\mathrm{OP}$} & - Postos de saúde, creches, escolas, moradias, etc. \\
\hline & & $\begin{array}{l}\text { - Saneamento, transporte público, qualidade dos serviços } \\
\text { de saúde (Hospital). }\end{array}$ \\
\hline \multirow{2}{*}{$\begin{array}{c}\text { Limitações na incidência na } \\
\text { elaboração estratégica da } \\
\text { cidade }\end{array}$} & \multirow{2}{*}{$\begin{array}{c}\text { OP } \\
\text { AMPP }\end{array}$} & • Enfrentamento ao capital, política de impostos, etc. \\
\hline & & $\begin{array}{l}\text { - Política de demolição de moradias, divisão política } \\
\text { administrativa, política da energia em Varadero, etc. }\end{array}$ \\
\hline \multicolumn{3}{|c|}{$\begin{array}{l}\text { Incredibilidade do OP e da AMPP como mecanismos democráticos, por parte de certa fração da } \\
\text { população (Delegados, habitantes). }\end{array}$} \\
\hline
\end{tabular}

Fonte: Pesquisa de campo, 2015/2016.

\footnotetext{
${ }^{114}$ As distintas Comissões podem funcionar em algum momento para contribuir na definição de políticas a serem executadas. No entanto, os entrevistados não reconhecem momentos nos quais isso tenha acontecido.
} 
O segundo aspecto relacionado com o papel do OP e da AMPP na geração de capacidades para o controle das decisões sobre os assuntos públicos são suas respectivas contribuições para informar e debater (refutar e aceitar) as decisões antes de serem aprovadas e executadas, aspecto esse onde também foram achadas mais diferenças do que semelhanças.

Conforme expressaram certos atores em PA (Gestores dos CARs, Conselheiros, agentes da prefeitura), o OP oferece capacidades para que a população seja informada sobre as decisões antes de serem tomadas e executadas. As ferramentas que facilitam esse processo são os FROP, o COP, assim como as funções dos Conselheiros do OP. Igualmente, esses atores afirmaram que, ligado a esse processo, o OP viabiliza discussões para aceitar ou refutar as decisões antes da sua adoção e execução. Sem embargo, outros atores (Delegados e habitantes) declararam algumas restrições nas capacidades da população para discutir e rejeitar decisões.

Esses sujeitos expressaram que, embora algumas decisões pontuais tenham sido refutadas, isso não acontece usualmente no cenário macrossocial do território e em relação a assuntos mais profundos da realidade em PA. Acontece, principalmente, no âmbito mais concreto, como nas comunidades e bairros, também relacionados com aspectos paliativos, conforme já se falou em seções anteriores.

$\mathrm{Na}$ experiência em Cárdenas, também se reconheceu que nos marcos da AMPP possibilitam que a população se mantenha informada sobre as decisões realtivas aos assuntos públicos. Porém, essas informações geralmente não são oferecidas antes da adoção e execução. Como um possível reflexo dessas limitações, poder-se-ia considerar o fato de que os sujeitos entrevistados não colocaram exemplos concretos que demonstrassem as capacidades em questão. Somente um dos entrevistados assinalou a experiência de unificação de Cárdenas com Varadero, como decisão que foi informada antes da sua execução, mas não antes da sua adoção. 
Outros pontos a serem tratados em relação à AMPP e que têm uma convergência com o OP, são, por um lado, falta de capacidade para rejeitar decisões sobre questões macro; por outro, as restrições na promulgação de debates para refutar e aceitar as decisões a serem executadas, embora nesse ponto a experiência do OP mostre uma realidade mais favorável.

Enquanto que nos marcos do OP a rejeição de decisões acontece sobretudo associada ao âmbito local (bairros, comunidades), segundo Delegados e habitantes de Porto Alegre, no âmbito das Rc e SeAMPP, essa rejeição geralmente não tem acontecido nem sequer nesse âmbito local, julgando pelas experiências dos atores cardenenses. Constata-se essa limitação no fato de que nenhum dos sujeitos entrevistados em Cárdenas apresentou exemplos onde determinada decisão tenha sido rejeitada. Essa realidade tem uma conotação diferente em PA, onde foram apontados exemplos de rejeição de decisões em vários dos aspectos.

De igual forma, mais um aspecto que marca a diferença entre o OP e AMPP e foi apontado pela maior parte dos atores entrevistados é o papel do governo antes de adotar e executar determinadas decisões. Em PA se reconhece que o governo indaga previamente a população ao tomar decisões, de modo que elas possam ter maior aceitação entre os cidadãos. Em Cárdenas não houve declarações sobre o reconhecimento desse papel do governo diante das decisões a serem adotadas.

O Quadro a seguir reflete de forma sintetizada os aspectos tratados, referidos às contribuições do OP e da AMPP para informar e debater as decisões a serem tomadas e executadas.

\section{Quadro 8 - Debater, refutar e aceitar decisões antes de serem tomadas e executadas.}

\begin{tabular}{c||c|c|}
\hline $\begin{array}{c}\text { Semelhanças OP e AMPP (Rc- } \\
\text { SeAMPP) }\end{array}$ & \multicolumn{2}{c}{ Diferenças OP e AMPP } \\
\hline \hline $\begin{array}{c}\text { Mantém a população informada } \\
\begin{array}{c}\text { sobre decisões relativas aos } \\
\text { assuntos públicos: }\end{array}\end{array}$ & $\{$ OP & $\begin{array}{l}\text { - Geralmente antes de serem tomadas e } \\
\text { executadas. } \\
\bullet \begin{array}{l}\text { Colocaram exemplos onde a população foi } \\
\text { informada antes de executar decisões. }\end{array}\end{array}$ \\
\hline
\end{tabular}




\begin{tabular}{|c|c|c|}
\hline & AMPP & $\begin{array}{l}\text { - Nem sempre são informadas antes de serem } \\
\text { tomadas e executadas. } \\
\text { - Não colocaram exemplos. }\end{array}$ \\
\hline \multirow[b]{2}{*}{$\begin{array}{l}\text { Restrições na promulgação de } \\
\text { debates para refutar e aceitar as } \\
\text { decisões a serem executadas. }\end{array}$} & \multirow{2}{*}{$\begin{array}{c}\mathrm{OP} \\
\text { AMPP }\end{array}$} & $\begin{array}{l}\text { - A rejeição de decisões acontece sobretudo no } \\
\text { âmbito local, e mais concretamente, ao nível } \\
\text { dos bairros (segundo Delegados e habitantes). } \\
\text { - Alguns atores desconhecem a ocorrência de } \\
\text { rejeição de decisões na sua totalidade. } \\
\text { - Reconhece-se que o governo indaga na } \\
\text { população antes de tomar decisões. }\end{array}$ \\
\hline & & $\begin{array}{l}\text { - A rejeição de decisões usualmente não } \\
\text { acontece nem sequer no âmbito local, e mais } \\
\text { concretamente, ao nível dos bairros (segundo } \\
\text { Delegados, habitantes, Pcp). } \\
\text { - Atores desconhecem a ocorrência de rejeição } \\
\text { de decisões (Delegados, habitantes, Pcp). } \\
\text { - Não houve declarações sobre se o governo } \\
\text { indaga ou não na população ao tomar } \\
\text { decisões. }\end{array}$ \\
\hline \multicolumn{3}{|c|}{$\begin{array}{l}\text { Não se reconhecem pela maioria dos atores capacidades para rejeitar decisões sobre questões } \\
\text { "macro". }\end{array}$} \\
\hline
\end{tabular}

Fonte: Pesquisa de campo, 2015/2016.

O terceiro e último aspecto que sintetiza as principais semelhanças que, entre suas diferenças, apresentam o OP e a AMPP, é o papel desses mecanismos na supervisão da execução das decisões tomadas nos seus respectivos territórios, evidenciando certo equilíbrio entre ambos os casos. Segundo a maioria dos entrevistados em Porto Alegre, o OP contribui para que a população acompanhe e fiscalize a execução das decisões, principalmente aquelas relacionadas à construção de obra nos bairros e na cidade. As formas estabelecidas para materializar esse processo são precisamente: as PR, as Assembleias temáticas, os Conselheiros, o PI, as diferentes Comissões (de obras, de Educação, de Saúde, entre outros), assim como o projeto OBSERVAPOA.

Coincidentemente, em Cárdenas também se apreciam formas destinadas a facilitar o acompanhamento por parte da população da execução das decisões tomadas, embora os sujeitos entrevistados não tenham sido abrangentes nas suas respostas. As capacidades que têm a população para concretizar o processo que se 
trata recaem sobre: os papéis dos Dc, dos Pcp, as Comissões de Trabalho, as Rc e as SeAMPP.

Apesar das mencionadas capacidades observadas nas duas cidades investigadas, existem algumas falhas que constituem mais uma similitude reconhecida por certos atores. Do ponto de vista prático, tanto o OP quanto a AMPP atualmente não conseguem ser suficientemente eficientes na disponibilização de capacidades para que a população fiscalize as decisões, segundo os discursos de Delegados e habitantes.

No caso de Cárdenas, essas ineficiências estão relacionadas aos modos de construção social que historicamente se têm configurado sobre os principais agentes encarregados por executar os processos de fiscalização. Essas formas definem um ator com pouca legitimidade como autoridade popular para fiscalizar determinadas decisões. Isso está relacionado aos papéis que, na prática, eles têm assumido, como intermediários entre o governo e os cidadãos para "levar" e "trazer" informações.

Em Porto Alegre, no entanto, as limitações estão apoiadas em outro aspecto e recaem basicamente no papel das Comissões. Alguns atores expressaram que elas não têm sido uma realidade universalizada em toda a cidade e, ainda, nos últimos anos a fiscalização não tem funcionado sobre a base dessas Comissões. Esse argumento revela que, mesmo com a relativa deficiência desse último procedimento, o OP oferece capacidades mais evidentes para supervisar a execução das decisões.

O Quadro 9 apresenta uma síntese do papel do OP e da AMPP para facilitar que a população supervisione a execução das decisões tomadas: 
Quadro 9 - Supervisão da execução das decisões tomadas

\begin{tabular}{|c|c|c|}
\hline $\begin{array}{c}\text { Semelhanças OP e AMPP } \\
\text { (Rc-SeAMPP) }\end{array}$ & & Diferenças OP e AMPP \\
\hline \multirow{2}{*}{$\begin{array}{l}\text { Capacidades para } \\
\text { supervisionar a execução das } \\
\text { decisões no território. }\end{array}$} & \multirow{2}{*}{$\begin{array}{c}\text { OP } \\
\text { AMPP }\end{array}$} & $\begin{array}{l}\text { - PR, as Assembleias temáticas, os Conselheiros, o } \\
\text { PI, as diferentes Comissões (de obras, de Educação, } \\
\text { de Suade, etc.), projeto OBSERVAPOA. } \\
\text { - Reconhecidas pela população. }\end{array}$ \\
\hline & & $\begin{array}{l}\text { - Dc, dos Pcp, as Comissões de Trabalho, as Rc e as } \\
\text { SeAMPP. } \\
\text { - Reconhecidas fundamentalmente no nível } \\
\text { normativo. }\end{array}$ \\
\hline \multirow{2}{*}{$\begin{array}{l}\text { Falhas nas capacidades para } \\
\text { supervisionar a execução das } \\
\text { decisões no território }\end{array}$} & \multirow[t]{2}{*}{ OP } & $\begin{array}{l}\text { - A não universalização das Comissões. } \\
\text { • Falhas no seu funcionamento. }\end{array}$ \\
\hline & & $\begin{array}{l}\text { - Sustentadas no papel prático historicamente } \\
\text { cumprido por Dc e Pcp, que os fazem perder } \\
\text { legitimidade como autoridade popular. }\end{array}$ \\
\hline
\end{tabular}

Fonte: Pesquisa de campo, 2015/2016.

A partir das similitudes e diferenças referentes aos mecanismos analisados e suas capacidades democratizadoras das decisões sobre os assuntos públicos, pode-se estabelecer um conjunto de reflexões que permitem retroalimentar as bases teóricas que sustentam a presente pesquisa. Simultaneamente, essa comparação coloca vários argumentos que facilitam dialogar com determinadas pesquisas realizadas sobre o objeto de estudo em questão, permitindo assim identificar as particularidades dos resultados mostrados.

Os resultados mostrados anteriormente corroboram a ideia de WHITEHEAD (2011) sobre a democratização constituir uma ferramenta conceitual e analítica susceptível de ser reconsiderada, em função das distintas experiências empíricas. Essa reconsideração se baseia numa série de elementos, derivando da comparação anterior, o que permite complementar alguns dos aspectos teóricos utilizados até o momento. 
Inicialmente, foi declarado que a democratização não constitui um estado final e predeterminado das relações entre os cidadãos e o Estado. Ela se configura como um processo de resultados a longo prazo que, por um lado, transforma constantemente as relações entre o Estado e a sociedade civil; por outro, modifica o equilíbrio entre as forças políticas e os poderes fáticos. Sem embargo, atendendo à comparação previamente exposta, se percebe uma realidade que favorece o aprofundamento das características do mencionado processo transformativo.

Nem sempre os processos de democratização implicam transformações constantes nas relações entre o Estado e a sociedade civil ou modificações no equilíbrio entre as forças políticas e os poderes fáticos. Conforme podem acontecer retrocessos (desdemocratização) nos processos de democratização, alguns dos resultados aqui mostrados demonstram que também podem acontecer estancamentos sustentados na manutenção de requisitos mínimos de democratização ${ }^{115}$, sem que isso implique necessariamente um retrocesso ${ }^{116}$.

Diante dessa problemática, que foi visualizada essencialmente na experiência cubana, qualquer leitor poderia arguir ao declarar que não se estaria na presença de um processo de democratização, senão de desdemocratização. Porém, valorizando as semelhanças achadas entre ambas as experiências, se colocariam contradições para assumir o inegável caráter democratizante do $\mathrm{OP}$, baseado nas suas conquistas em termos democráticos (SANTOS e AVRITZER, 2002; MARQUETTI, 2002; LUCHMANN, 2002; GONZÁLEZ, 2007; AVRITZER, 2014) que simultaneamente não desmerecem reconhecer certas limitações, associadas ao pouco empoderamento da população perante decisões vinculadas a determinadas áreas da sociedade.

O que se percebe no caso da experiência cubana é que as relações de poder entre o Estado e a sociedade civil ante as decisões, assim como esse suposto

\footnotetext{
${ }^{115}$ Essa ideia também tem relação com algumas reflexões sobre Democracia, onde se reconhecem que certos regimes políticos na prática funcionam sobre a base de princípios democráticos mínimos (DAHL, 2005).

116 Esse estancamento em algum momento poderia ser considerado como retrocesso (ou desdemocratização), dependendo das lógicas de interconexão entre Estado/sociedade civil e os diferentes contextos sociais.
} 
equilíbrio entre as forças políticas e os poderes fáticos, há algum tempo se mostra mais favorável ao governo. A estrutura democrática no nível local (Dc, Pcp, SeAMPP, Rc, etc.) tem adquirido um caráter mais formal que lacera as reais capacidades democratizadoras das decisões sobre os assuntos públicos, o que facilita maior autonomia governamental diante dessas decisões. O resultado disso é um relativo estancamento, mais do que um retrocesso ${ }^{117}$, das capacidades dos cidadãos para democratizar as decisões sobre os assuntos públicos, que se visualizam em alguns dos aspectos tratados nos três eixos analíticos desenvolvidos até o momento.

Um desses aspectos se constata nas capacidades que oferecem o OP e a AMPP para que a população incida na definição das condições para a tomada de decisões. $\mathrm{O}$ fato de que existam mecanismos como o OP, as Rc e as SeAMPP (essas últimas nos marcos da AMPP), com orientações vinculadas ao estabelecimento de relações entre o Estado e a sociedade civil para a tomada de decisões, implica um sinal de democratização.

Não obstante, na hora em que ambos os mecanismos consigam tolher tentativas espontâneas da população para estabelecer mecanismos alternativos, se revela a possibilidade de um estancamento em termos de democratização, com diferentes graus de desenvolvimento. Particularmente, esse potencial estado de estancamento se relaciona a uma das implicações da democratização: as constantes transformações das relações democráticas entre o Estado e a sociedade civil ${ }^{118}$, pois ditas relações são estabelecidas essencialmente sobre a base de mecanismos e procedimentos. A principal decorrência dessa retaliação é precisamente a relativa

${ }^{117}$ A ideia do retrocesso não se descarta totalmente nesta análise. Reconhece-se que os dados oferecidos poderiam torná-la mais apropriada para alguns leitores. No entanto, para se ter uma avaliação mais aprofundada que a reafirme ou descarte, seria imprescindível aplicar as categorias analíticas aqui utilizadas a partir de uma perspectiva diacrônica. Portanto, enquanto essa análise diacrônica não seja feita, nesse trabalho se assumirá como válida a ideia do estancamento, sempre lembrando que esse estancamento não tem um caráter linear estável. Ele convive com um processo onde se percebem simultaneamente avanços e retrocessos em termos de democratização. Portanto, esse último também poderia ser considerado um processo híbrido em relação às suas características.

118 É preciso reconhecer que o estancamento pode ser considerado relativo na experiência do OP, pois as discussões sobre mecanismos complementares permitem certa mobilização. Mas de outro ponto de vista é viável considerar esse estancamento, já que a não possibilidade de estabelecer mecanismos alternativos limita as transformações constantes da relação entre o Estado e os cidadãos, em determinadas áreas como bem tem sido visível. 
monopolização democrática que se observa nas duas experiências e que foi reconhecida por vários atores.

Tal monopolização, que tem sido chamada de relativa, pretende destacar que nas duas experiências ela se mostra de forma diferenciada, enquanto mantém o mencionado aspecto comum. Essencialmente, essa diferenciação se observa no fato de que o OP tem maior capacidade para se constituir como um processo autorregulado popularmente, que pode assumir diversas formas (simplificação, complexão e articulação com outras instituições) segundo os contextos sociais (SANTOS, 1998; ABERS, 2000; AVRITZER, 2002a, 2014).

O segundo aspecto, que poderia indicar um estancamento das transformações constantes nas relações entre o Estado e a sociedade civil ou nas modificações no equilíbrio entre as forças políticas e os poderes fáticos, está relacionado às capacidades de sanção sobre os atores políticos que ambos os mecanismos proporcionam, reconhecendo que, nesse ponto, se precisaria de uma análise mais profunda para chegar a conclusões mais objetivas.

Tanto em Porto Alegre quanto em Cárdenas, existem oportunidades para que a população exerça sanção sobre os atores políticos, fundamentalmente a partir de uma perspectiva política. Nesse sentido, o OP apresenta melhores resultados, conforme já foi exposto. No entanto, ao analisar minuciosamente os argumentos oferecidos sobre a temática em questão, se percebem alguns critérios que favorecem a ideia de um possível estancamento.

Apesar das atuais capacidades de sanção dos habitantes de Porto Alegre, obtidas mediante o OP, a população ainda não é considerada ao se tomar decisões mais profundas e gerais dentro da estrutura de poder que envolve a cidade. Essa situação constitui um dos fatores explicativos da quantidade de demandas ainda sem resposta do governo, assim como da reprodução e persistência de problemáticas 
mais globais, como desigualdade, pobreza e violência ${ }^{119}$. Outro aspecto refere-se à pequena quantidade populacional que consegue ser relativamente empoderada mediante o OP. Caso a população participativa fosse maior, aumentariam as capacidades dos cidadãos para democratizar as decisões sobre os assuntos públicos, com base em pressões populares e sanções mais profundas sobre a "máquina" administrativa.

Nas duas realidades se insinua que, em certos aspectos, o OP pode padecer de um estancamento nas transformações e modificações nas relações entre governo e cidadãos e entre as forças políticas e os poderes fáticos, que implicam a democratização. Esse argumento se sustenta na importância que tem a ampliação de espaços a serem democratizados para impulsionar os citados processos, assim como o aumento da quantidade e heterogeneidade da população participante do $\mathrm{OP}^{120}$.

Um último aspecto que sugere considerar a ideia de um estancamento como característica da democratização está relacionado à incapacidade dos cidadãos de Cárdenas para rejeitar decisões sobre determinados assuntos públicos. Essa incapacidade, por um lado, reflete o nível de paralisação que as relações democráticas entre o Estado e sociedade civil adquiriram nesse território. Por outro, elas se instituem como fator que contribui para reproduzir resistências durante o processo de transformações em áreas já mencionadas: relações entre governantes e governados e também configuração das forças políticas e dos poderes fáticos.

Essas limitações da população cardenense permitem dialogar com uma das questões que tem estado muito presente nos debates sobre experiências como o OP e sua relação com a teoria democrática. Trata-se do destacado papel do desenho institucional no êxito da democratização das decisões públicas. Embora autores como Avritzer (2014) reconheçam que o desenho institucional não constitui o fator

\footnotetext{
119 Também deveria ser considerada a questão financeira como outro dos fatores determinantes, de acordo com a maioria dos atores que colaboraram com a atual pesquisa.

${ }^{120}$ Pelo menos no referente a esse ponto, o estancamento em ambas as experiências poderia ser substituído pela ideia de um retrocesso, dependendo das suas referências históricas.
} 
determinante do desenvolvimento democrático local, as restrições para rejeitar decisões em Cárdenas retificam essa afirmação.

Apesar das suas singularidades e limitações, o desenho institucional no nível municipal cubano incorpora certas capacidades para que os cidadãos cumpram um papel fundamental na democratização das decisões através da figura dos Dc, Pcp e das funções Rc e SeAMPP (BRIGOS, 1998; PAZ, 2009; AUGUST, 2015). Não obstante, se percebe que a práxis em termos de reações democráticas entre o governo e os governados fica encoberta por uma realidade normatizada. Sendo assim, os níveis práticos e subjetivos se instituem como umas das principais dificuldades para o aprofundamento paulatino da democratização.

Dessa contradição deriva a confirmação do argumento de AVRITZER (2014) para quem o desenho institucional nem sempre constitui um fator fundamental na consolidação da democratização, pois ela está mediada por outros fatores (como os subjetivos), que dependendo dos contextos podem ter mais influências do que outros. Nesse cenário, aparece um caminho para possíveis pesquisas futuras, que permitam aprofundar o papel da subjetividade nos processos democráticos considerando as experiências examinadas.

Seguindo com os elementos que permitiram complementar alguns dos aspectos teóricos utilizados até o momento, é necessário destacar uma das ideias colocadas por O'DONNELL e SCHMITTER (1991). Os dois autores expressam que num processo de democratização, o governo tem o direito de agir com autoridade e, se for o caso, com medidas coativas, a fim de promover a eficácia das opções eleitas e proteger o sistema político de ameaças que perturbem o seu desenvolvimento. Não obstante, o caso cubano permite discorrer criticamente com esse argumento.

O processo de descentralização em Cuba, que levou à criação dos OMPP (governos municipais) em 1974 e suas posteriores modificações com a criação dos Dc, Pcp, Rc e etc., esteve simultaneamente sustentando numa centralização cujo fundamento se baseia na ideia de proteção do sistema político socialista contra 
ameaças externas e/ou internas ${ }^{121}$. Essa proteção tem aprofundado a centralização do Estado no desenho e execução de decisões sobre os assuntos públicos (CHAGUACEDA e GEOFFRAY, 2013) ${ }^{122}$, e através do tempo tem criado limitações tanto práticas quanto subjetivas nos processos de democratização. Um reflexo dessas limitações práticas é precisamente o estancamento antes descrito, entendido como base das restrições dos cidadãos para incidir na configuração das condições da tomada de decisões, assim como para controlar os atores políticos e as decisões.

Por outro lado, especificamente no âmbito subjetivo, a atitude protecionista do Estado cubano também tem levado à configuração de uma forma de construção social da política, que limita a democratização como processo de transformações constantes nas relações entre o Estado e a sociedade civil. Esse processo de transformações constantes passa pela necessária existência de uma cidadania subjetivamente preparada e firme, permeada de um sentido critico que institua uma força de poder capaz de pressionar, controlar e mobilizar as forças políticas.

Nesse processo de construção subjetiva dos cidadãos favorável à democratização cumprem um importante papel a história (RINGER, 2004) ${ }^{123}$ e o Estado (O’DONNELL, 2008, 2010). Esse último, essencialmente, como entidade responsável por facilitar estruturas que beneficiem a produção e reprodução de elementos cognitivos, afetivos e simbólicos, onde os próprios cidadãos reconheçam seus direitos e se autointerpretem como sujeitos ativos na construção da política.

Perante a imprescindível identificação que deve existir entre as subjetividades construídas e o funcionamento das estruturas (mecanismos, normativas, espaços) nos processos democráticos, a centralização cubana sustentada no princípio de proteção do sistema se configura como limitante para a edificação

\footnotetext{
${ }^{121}$ Para mais informação sobre a centralização/descentralização em Cuba, ver: PAZ (2009).

${ }^{122}$ Esse grau de centralização, caracterizado por uma direção vertical, desde uma perspectiva mais critica é denominado de "monopólio estatal" por esses autores.

${ }^{123}$ Para compreender a configuração da subjetividade política dos cidadãos é importante ter em conta o que RINGER (2004) chamou de "trajetória de dependência": assumir a história como fatos influentes (não de maneira mecânica) dos fenômenos sociais.
} 
das citadas realidades subjetivas. Consequentemente, a ideia de O'DONNELL e SCHMITTER (1991) sobre o direito do governo de agir com autoridade e, se for o caso, com medidas coativas, exige um exame mais cuidadoso, devido aos resultados que podem acarretar na prática democrática, sem esquecer os possíveis vazios gnosiológicos na análise do mencionado processo $^{124}$.

Desde esse último ponto de vista, se recomenda ter uma aproximação aos processos de democratização, considerando o papel que o Estado cumpre historicamente na construção de cidadãos responsáveis e criticamente reflexivos. Qualquer processo de democratização seria restrito sem a existência de cidadãos com essas características, conforme mostram alguns dos resultados exibidos.

Por conseguinte, desconsiderar o papel do Estado na necessária construção subjetiva dos cidadãos em função da democratização pode levar à omissão de elementos relevantes para a avaliação de questões centrais nos processos democráticos $^{125}$. Um desses elementos são as formas históricas de distribuição de poder entre os dois setores, assim como as formas de dominação e legitimação desse poder.

Reconhecer essas realidades pode oferecer melhores condições para identificar as tentativas maniqueístas da democracia, partindo de melhores leituras sobre as reais capacidades dos cidadãos para incidir na democratização no modo aqui assumida. Essas capacidades serão cada vez mais verdadeiras na medida em que se facilitem não só mecanismos sobre os quais os cidadãos possam exercer seus direitos para participar da construção da política, como também condições

\footnotetext{
${ }^{124}$ Em relação à necessária articulação entre o Estado a subjetividade dos cidadãos, nesse caso no relativo aos processos democráticos, KELSEN (1997) adverte uma ideia importante, para pensar nos desafios do sistema político cubano. A não atualização constante dos nexos entre a população e o Estado pode derivar um estado de autoritarismo, que não provém da atuação injusta desse último. Pelo contrário, esse autoritarismo teria suas bases no funcionamento do Estado a partir de contextos de sentidos, que a população reconheceria como próprios.

${ }^{125}$ LECHNER (1986, p. 35) expressou que o principal vazio no debate sobre a democratização reside na ausência de uma reconceptualização do Estado como estado democrático. Essas ideias foram aprofundadas posteriormente por pensadores como O'DONNEL (2004, 2008, 2010). No entanto, nesse sentido, aqui se reafirma que uma via para repensar o Estado nos termos desse autor radica precisamente no seu papel no processo de construção subjetiva (democrática) dos cidadãos.
} 
cognitivas para que esses cidadãos possam fazer um uso adequado e eficiente desses mecanismos.

A presença de um desencontro entre o funcionamento estatal em função da criação de capacidades cognitivas serviria para aprofundar realidades contrapostas à democratização. Uma delas é tirar poder dos cidadãos e facilitar a legitimação da dominação que essa ausência de poder implica. A outra realidade é a desautonomização (AVRITZER, 2014) da sociedade civil ou alguma parte dela (como parece ter ocorrido), porquanto o papel passivo do Estado nesse processo construtivo da subjetividade pode ser considerado uma forma sutil de minimizar as capacidades de autonomização social.

Expostas essas ideias teóricas, é possível apreciar como em ambas as experiências analisadas (o OP em Porto Alegre e a AMPP em Cárdenas) o Estado assume um papel ativo na criação da estrutura democrática no nível municipal ${ }^{126}$. E esse papel pode ser considerado um passo significativo em termos não só da democratização, mas também em termos da construção de cidadãos criticamente responsivos. No entanto, através do tempo, se observam características peculiares nesse sentido, porquanto no desenvolvimento de ditas experiências o Estado foi assumindo atitudes diferenciadas. Em Porto Alegre, o governo assume um modo mais aberto, deixando para a população alguns espaços para a reconfiguração dessa estrutura. No caso de Cárdenas, o governo opta por centralizar as decisões em relação à configuração da estrutura em questão ${ }^{127}$.

Sem dúvida alguma, essa função assumida pelo Estado cubano incide sobre parte da população, propiciando que alguns dos atores e representantes populares

\footnotetext{
${ }^{126}$ Esse papel do Estado em Porto Alegre e em Cárdenas não deve ser homologado totalmente nem visto por uma perspectiva acrítica. Existem critérios de atores entrevistados declarando que o surgimento do OP em Porto Alegre tinha como propósito fundamental legitimar o governo do PT, diante da estrutura de distribuição de poder entre partidos que existia na época. Uma situação similar pode ser assumida a partir da experiência em Cárdenas, porquanto que alguns atores reconhecem que a criação dela entre outras coisas tem facilitado a direção centralizada dos territórios e, portanto, não tem implicado uma real distribuição de poder até a população, perante determinados cenários.

${ }^{127}$ No presente trabalho, não se pretende responsabilizar exclusivamente o Estado pela construção das subjetividades políticas. Essa construção é um processo histórico e multidimensional que inclusive reconhece o papel da própria população nesse processo construtivo. No entanto, não se pode descartar que, no caso de Cuba, o Estado tem uma grande responsabilidade no mencionado processo.
} 
encarregados por impulsionar os processos de democratização tenham subjetividades concretas que limitam suas capacidades democráticas (ESPINA, 2006; SUÁREZ, 2011 ${ }^{128}$; GUACH e NEGRI, 2016). Fundamentalmente, no que tange às suas capacidades para estabelecer mecanismos alternativos e/ou complementares que facilitem os debates e a tomada de decisões em função dos interesses populares; estabelecer normativas para configurar os processos decisórios (incidir na definição das condições para a tomada de decisões); pressionar, rebater e sancionar os atores políticos e suas decisões; incidir na configuração das políticas públicas, assim como aceitar e/ou refutar as decisões sobre os assuntos públicos, antes de elas serem executadas (o controle dos atores políticos e das decisões).

De modo particular, no que diz respeito às capacidades de aplicar pressão popular no governo municipal, sancioná-los e rebater as decisões, observa-se uma diferença significativa entre o OP e AMPP, estando essas capacidades mais claras no caso do OP. Uma das principais determinantes dessas capacidades são as formas subjetivas e práticas apreendidas historicamente, a partir das quais os cidadãos se autopercebem como sujeitos ativos na configuração da política. Essa autopercepção estimula a diferença nas posturas assumidas pelos entrevistados, em relação à pressão que eles poderiam exercer sobre a administração local como importante via para melhorar o desempenho governamental ${ }^{129}$.

Assim sendo, considerando os aspectos antes explicitados relativos ao papel do Estado na construção da subjetividade democrática, é necessário que qualquer teorização sobre a democratização valorize a dimensão subjetiva do processo e suas relações de determinação com outros componentes como, por exemplo, aspectos estruturais $^{130}$, essencialmente, as influências que a gestão governamental tem na

\footnotetext{
${ }^{128}$ Essa ideia concorda com os argumentos de SUÁREZ (2011), que a partir de uma pesquisa sobre os imaginários políticos na província de Matanzas identificou um fraco imaginário da população (sobretudo jovem) como protagonistas na configuração da política.

129 Tal relação entre a pressão popular e o aprimoramento da governabilidade já foi reconhecido por autores como MARQUETTI (2002) como um elemento fundamental para pensar e analisar as necessárias sinergias entre reformas do Estado e formas ampliadas de participação. Isso tudo, a partir das suas análises sobre o OP.

${ }^{130}$ HABERMAS $(1998,2005)$ propõe algo parecido quando se refere à democracia deliberativa.
} 
configuração subjetiva dos cidadãos e nos modos de produzir, reproduzir e legitimar suas incapacidades democráticas ${ }^{131}$.

Sobre a questão da legitimação, ainda é preciso destacar mais alguns elementos que justificam sua necessária consideração numa análise sobre a democratização. As interpretações e os graus de aceitação do governo por parte da população, assim como as justificativas dessas formas de construção social, constituem importantes indicadores da "saúde" do processo em questão.

Tanto em Cárdenas quanto em Porto Alegre, as ferramentas democráticas examinadas contribuem para legitimar a estrutura governamental. Essa legitimação se pode evidenciar nos graus de aceitação que o governo tem entre alguns setores da população. Porém, quando se aprofunda nas lógicas desses processos de legitimação, sobressaem aspectos que permitem assumir uma posição mais crítica sobre a democratização que se desenvolve a partir do OP e da AMPP, assim como das capacidades que são outorgadas à população para fazer parte desse último processo.

A principal estratégia que sustenta a legitimação do governo em Porto Alegre mediante a ação do OP consiste nos vínculos que essa ferramenta promove entre a população e os atores governamentais. Esses vínculos facilitam que determinadas decisões estejam de acordo com os interesses e as necessidades de certa parte da população, fazendo com que o governo adquira legitimação entre alguns setores sociais. Sobre essa sinergia entre decisões governamentais e interesses populares, autores como LUCHMANN (2002, p. 143) e SANTOS e AVRITZER (2002) ressaltam as capacidades do OP para constituir instâncias deliberativas, troca de argumentos e articulação normativa nos processos deliberativos, constituindo umas das principais determinantes da sustentabilidade do próprio OP e das práticas participativas.

\footnotetext{
${ }^{131}$ Sobre a importância da subjetividade nos processos democráticos, NOHLEN (2003), expressou que um dos maiores vetores para a consolidação democrática na América Latina recai sobre a cultura política e, especificamente, sobre a ética política como dimensão axiológica. Isso tudo, visto como o conjunto de valores que guiam o pensamento e as atitudes dos cidadãos, principalmente dos políticos.
} 
Nos marcos do OP, a população porto alegrense, além de conseguir discutir sobre algumas decisões a serem tomadas, também logra discutir as atitudes e as formas de proceder do governo na sua relação com os atores do OP e/ou com a população em geral. De igual modo, essa população ainda obtém capacidades para estabelecer cobranças desses agentes governamentais.

A partir desses dois aspectos, se viabiliza então que a população participante do OP veja, em certa medida, representadas suas demandas nas decisões governamentais e que consiga mudar alguns fundamentos práticos dos atores políticos a partir da vontade popular ${ }^{132}$. Assim sendo, esses processos facilitam por fim que boa parte dos atores que participam do OP assuma o caráter legitimamente democrático do governo no nível local.

Sem embargo, os problemas que essa população tem para exercer cotas mais efetivas de democratização geralmente não são muito reconhecidas em Porto Alegre (pelo menos entre a maioria dos atores entrevistados), como resultante desse próprio processo de legitimação, sem esquecer as declarações de atores como Delegados do OP e alguns habitantes.

Sem desmerecer os êxitos do OP na democratização de decisões sobre aspectos específicos e paliativos (que justificam sua necessária existência), ele se estabelece como uma ferramenta tática para a política dos governos, a partir do qual não se consegue uma reestruturação democrática significativa, no sentido de alguma transformação dentro da estrutura interna de participação e do poder sobre a cidade. Por conta disso, se aprecia uma ferramenta que fundamentalmente discute sobre a organização do espaço urbano e os seus aprimoramentos, a exemplo de saneamento básico, construção de escolas, iluminação pública e outros serviços públicos.

Por outro lado, em Cárdenas, as Rc e SeAMPP (nos marcos da AMPP) também contribuem para legitimar as estruturas governamentais, mas a partir de

\footnotetext{
${ }^{132}$ Constituem-se como um exemplo de fundamentos práticos as próprias inter-relações que, para discutir e decidir sobre certos assuntos do território, se estabelece entre o governo e a sociedade civil nos marcos do OP, sendo esse um simples acordo entre essas frações da sociedade.
} 
lógicas diferentes. A concordância entre decisões tomadas pelo governo e certos interesses populares (educação, saúde, segurança) continua sendo uma ferramenta que outorga legitimidade a essas estruturas. Contudo, não é uma legitimidade que se estabelece a partir de soluções, decisões e/ou da organização de debates críticos e sistemáticos junto às comunidades, senão que se configura através dos papéis históricos assumidos pelo Estado, como máximo responsável e provedor das soluções para as problemáticas sociais ${ }^{133}$.

Dito de outra maneira, a legitimação do governo decorre da imagem construída sobre ele como principal sujeito configurador da política, que minimiza o papel da cidadania nesse processo ${ }^{134}$. Sendo assim, persiste a ideia de que "aqueles são o governo, nos somos o povo", deixando que as problemáticas sociais se resolvam de forma indireta mediante a ação do Estado.

De forma geral, os argumentos expostos relacionados com a legitimação do governo a partir da execução do OP, das Rc e das SeAMPP revelam mais um componente a ser considerado na teorização sobre a democratização. Historicamente, o Estado tem constituído uma estrutura de coerção e centralização do poder, cuja análise em termos de distribuição desse poder com a sociedade civil se faz imprescindível para entender os citados processos. Portanto, com os resultados aqui expostos, se reafirma a importância de considerar o papel das estruturas do Estado (como o próprio governo) na transferência de espaços e de poder que permita à população influir nas decisões importantes sobre os assuntos públicos. Esta ação poderá constituir mais uma forma de diminuir os erros gnosiológicos, derivados de possíveis diagnósticos precipitados da democratização ${ }^{135}$.

\footnotetext{
${ }^{133}$ Associado a essa ideia, SUÁREZ (2011, p. 127) argumentou que o sujeito social cubano é um sujeito de governo não porque sua participação seja direta e ativa, mas porque ele é capaz de expressar suas expectativas sociais e se deixar governar (guiar) por seus lideres governamentais.

${ }^{134}$ Essa problemática está associada precisamente às formas centralizadas de dirigir os territórios, que tem feito da sociedade civil um ator passivo na configuração das decisões e da política.

${ }^{135}$ Essa ação é importante para avaliar a vontade política e os seus impactos na transferência de poder para a cidadania. Essa vontade política, junto a outros fatores (densidade associativa, elementos de desenho
} 
Um último elemento a ser estimado no que tange à teorização e análise dos processos de democratização se relaciona com a contextualização das decisões democratizadas. Quais decisões têm sido democratizadas pelos mecanismos analisados? Quais são os significados e a importância que essas decisões têm para a população e para o governo, em determinados contextos históricos (nacional e internacional)? Quais são as implicações dessas decisões em termos de distribuição de poder entre o Estado e a sociedade civil? Todas essas perguntas e outras possíveis precisam ser respondidas para se identificar e analisar com maior objetividade os processos de democratização, principalmente quando se pretende realizar análises comparativas, sejam sincrônicas ou diacrônicas, por casos diferentes ou similares.

Para BOURDIEU $(1975,1997)$ essa objetividade transcende a concepção positivista baseada na perspectiva desde "acima" e desde "fora" (neutralidade valorativa), insistindo na necessária reflexividade do sujeito pesquisador. Por conseguinte, para os fins analíticos da democratização aqui propostos, a noção de objetividade adquire conotações similares.

Sem pretender adentrar no detalhamento do papel que deve assumir o sujeito pesquisador na produção de conhecimentos sobre seu objeto de estudo (democratização), a objetividade na identificação de processos de democratização sugere assumir uma refletividade com referência nessas decisões que supostamente são democratizadas. Saber identificar os componentes sociais (interesses, subjetividades, estruturas, cojunturas, objetivos e outros) associados às decisões tomadas, seja como condicionantes ou como resultantes, permitirá diminuir equívocos na produção de conhecimentos, condicionados pela lógica do próprio processo $^{136}$.

institucional e capacidade administrativa e financeira), tem sido determinantes para a existência de diversas experiências democráticas e participativas. Entre elas, o próprio OP (AVRITZER, 2014).

${ }^{136}$ Partindo das próprias ideias de BOURDIEU (1997) sobre o campo social, por exemplo, para tentar entender algumas dessas lógicas, se assumiria então que a democratização constitui um conjunto de relações entre diferentes agentes sociais que, colocados em posições específicas dentro de um sistema de inter-relações, implicam relações de poder e tentativas de manutenção ou subversão de uma ordem determinada, sobre a base de estratégias condicionadas por certa distribuição de capitais (sociais, econômicos, culturas, políticos, etc.). 
Assim sendo, o reconhecimento desses possíveis equívocos e a sua superação facilitarão assumir criticamente o caráter democratizante de determinadas experiências, não precisamente pelo fato de promover capacidades para que a sociedade civil incida nas decisões sobre os assuntos públicos. Especialmente, esse caráter democratizante poderá ser determinado pelo tipo de decisões que a população consegue influenciar e suas implicações em dois aspectos fundamentais. O primeiro deles são suas implicações em termos de distribuição de poder. O segundo está vinculado às suas inferências como base das necessárias e paulatinas transformações e modificações nas relações entre governo e cidadãos e entre as forças políticas e os poderes fáticos, que aludem à democratização. Por conseguinte, a consideração do caráter contextualizado das decisões influídas pela sociedade civil institui mais uma ferramenta conveniente do ponto de vista epistemológico, que viabilizará obter visões mais precisas sobre as reais capacidades que a sociedade civil tem para incidir na configuração dos assuntos públicos e da política em geral. 


\section{CONSIDERAÇÕES FINAIS.}

No transcurso das análises referentes ao OP em Porto Alegre e à AMPP em Cárdenas e suas respectivas capacidades para democratizar as decisões sobre os assuntos públicos, foram expostas uma série de informações que, a partir de uma abordagem comparativa, permitiram compreender a lógica de funcionamento dessas experiências. Analisaram-se, particularmente, as capacidades que o OP e a AMPP dispõem para que a população incida em alguns campos dos processos de democratização. Esses campos são, especificamente, as condições que sustentam a tomada de decisões, o controle dos atores políticos e o controle das decisões sobre os assuntos públicos.

$\mathrm{Na}$ configuração das condições que sustentam os processos decisórios, observou-se que o OP apresenta maiores vantagens em relação com a AMPP no que concerne ao estabelecimento de mecanismos alternativos que favoreçam a tomada de decisões e os debates públicos. No entanto, nenhuma das duas ferramentas materializou esse tipo de mecanismos, apesar de certos atores (Delegados e habitantes) tenham expressado essa a necessidade. Decorre, assim, que tanto o OP quanto a AMPP tendem à monopolização dos processos democráticos nos seus respectivos territórios, a despeito das suas limitações para impulsionar o citado processo.

Essa monopolização se manifesta em Porto Alegre através da rejeição de tentativas espontâneas de estabelecimento de mecanismos alternativos, reconhecida por vários Delegados e habitantes. Entre essas tentativas se destacam, por exemplo, o Comitê Popular da Copa e a Voz do Usuário, conforme foi visto. Não obstante, também se observou que o OP ainda mantém uma vantagem em relação com a AMPP por facilitar a execução de procedimentos complementares. Os entrevistados em Cárdenas não reconheceram isso em relação à AMPP e, em Porto Alegre, esse 
processo tem favorecido os debates e a tomada de decisões sobre os assuntos públicos.

Em Cárdenas, a monopolização envolve a inexistência de debates sobre a possibilidade de criar mecanismos alternativos. Três principais fatores auxiliam a compreensão das causas da inexistência do debate. Primeiramente, a gênese da estrutura democrática, no nível municipal, é responsabilidade do governo. Por conseguinte, e derivando daí o segundo fator, cria-se o critério de que a criação de outros mecanismos é desnecessária, tendo como base a estrutura normativa que sustenta as lógicas da AMPP. Associado a esses dois fatores se encontra, por fim, um terceiro, que consiste na percepção dos cidadãos da impossibilidade de conseguir materializar os mecanismos alternativos.

Observaram-se, também, semelhanças em outras áreas associadas ao processo de democratização. Trata-se das capacidades que o OP e a AMPP oferecem para que a população faça parte de debates em que possam ser aceitas e refutadas as normativas para regularizar os processos decisórios sobre os assuntos públicos. Essas semelhanças se verificam nos discursos de alguns atores, como habitantes e Delegados do OP e da AMPP.

Com base nas falas desses atores, o OP e a AMPP são ferramentas que facilitam as capacidades para que a população incida na definição de regras que sustentam a tomada de decisões, mas apenas sobre assuntos bem específicos, como aqueles que podem ser considerados atenuantes das falhas do sistema social em geral que, conforme foi demonstrado, para cada caso tem suas peculiaridades. Por conta dessas limitações do OP e da AMPP, se reconheceu, por fim, que os governos ainda mantêm seu domínio sobre as lógicas que definem a tomada de decisões sobre assuntos públicos centrais, que constituem as principais determinantes das limitações e demandas populares tanto em Cárdenas quanto em Porto Alegre.

Ainda no âmbito das capacidades do OP e da AMPP para facilitar que os cidadãos incidam nas condições que sustentam os processos decisórios, se 
demonstrou que o OP possui melhores resultados no que diz respeito à definição e supervisão da agenda dos debates públicos por parte da população. Em Porto Alegre, as condições sobre as quais se define a agenda de debates tem um caráter mais democrático, pois a população atua de forma mais ativa na configuração dessas condições. Enquanto isso, em Cárdenas, o governo é o maior articulador da configuração dessas normativas, assim como da própria agenda de debates.

De igual modo, em relação às capacidades da população para supervisionar a definição da agenda de debates, o OP adquire um maior destaque, refletindo na variedade de procedimentos que contribuem para esse processo. Entre esses procedimentos se destacam o papel dos diferentes espaços de debates dentro do ciclo do OP, dos Delegados e Conselheiros, assim como a função do PI.

No concernente aos papéis que cumprem o OP e a AMPP na geração de capacidades para o controle dos atores políticos, também foram apresentadas algumas semelhanças entre as ferramentas. Nesse sentido, mostrou-se como estão concebidos nas suas lógicas de funcionamento certos instrumentos para propiciar a socialização de informações sobre a gestão governamental, relacionada às demandas púbicas. No caso do OP, esses instrumentos foram: o papel dos Delegados, Conselheiros do OP, as funções dos FROP, do COP e do PI, além da estratégia OBSERVAPOA. No caso da AMPP, se destacaram o papel dos Delegados e Presidentes dos Conselhos Populares, além das Rc e as SeAMPP.

Junto a esses argumentos sobre a socialização de informações, também se demonstrou como alguns espaços concebidos nos marcos dos mecanismos analisados contribuem para favorecer que a população avalie a gestão governamental sobre os assuntos públicos. No entanto, considerando os discursos dos entrevistados, constatou-se que na prática o OP tem sido mais exitoso em relação à socialização de informações sobre os assuntos públicos e com as capacidades outorgadas aos cidadãos para avaliar a gestão dos atores políticos diante desses assuntos. As justificativas desse maior êxito recaem no caráter mais amplo 
das informações que se socializam: ações e atitudes do governo, decisões tomadas, grandes normativas e a forma em que se executam, entre outras temáticas.

Não obstante às valorações positivas que foram exibidas sobre as capacidades analisadas do OP e da AMPP, foi verificado outro elemento comum entre esses mecanismos, que revelam algumas das suas limitações. Esse elemento é precisamente a necessidade de aprimorar esses mecanismos em função da socialização de informações.

No que diz respeito às capacidades de sanção que as ferramentas em questão disponibilizam, também foram expostas algumas semelhanças. A primeira dessas similitudes é que nenhum das duas experiências tem capacidades para executar sanções do ponto de vista legislativo, mas apenas por uma perspectiva política. Essas sanções políticas se materializam no poder dos cidadãos para promover a remoção dos atores governamentais dos seus cargos, mediante procedimentos particulares em cada experiência.

Apesar disso, a possibilidade de exercer esse poder não é isenta de limitações. Em ambas as experiências, alguns atores (habitantes e Delegados) expressaram que há restrições em termos de poder exercer "verdadeiras" sanções. Para o caso do OP, essas restrições foram justificadas mediante a quantidade de demandas sem serem atendidas. Em Cárdenas, justificou-se através das formas históricas de construção subjetiva da população em relação aos processos democráticos.

Outra dimensão de análise do presente estudo foi o papel do OP e da AMPP na geração de capacidades para o controle das decisões sobre os assuntos públicos, sobre a qual também se apresentaram algumas informações. Dentro desse eixo analítico, revelou-se que as duas ferramentas oferecem certas capacidades para que a população incida na definição das políticas públicas, tendo implicações e condicionamentos diferenciados. 
Umas das formas mediante as quais se exercem as mencionadas capacidades são as Comissões de trabalho integradas por lideranças populares. Essas Comissões, que funcionam como estratégia de análise da realidade social e de diálogo com o governo, em teoria, viabilizam certo grau de incidência na definição de políticas públicas. Contudo, as políticas que os dois mecanismos conseguem influenciar são aquelas ligadas fundamentalmente ao âmbito comunitário e mais imediato, através das Comissões e dos outros procedimentos que, dentro do OP e da AMPP (FROP, COP e Rc e SeAMPP, respectivamente), permitem encaminhar as inquietudes da população.

Entretanto, ainda há restrições nesse âmbito em ambas as experiências. Destacam-se, nesse sentido, a falta de recursos financeiros necessários para conseguir um maior impacto na configuração das políticas públicas, assim como as incapacidades tanto do OP quanto da AMPP para incidir na configuração estratégica da cidade no que tange a essas políticas. Em conjunto, essas limitações convergem para condicionar não só a falta de credibilidade (entre alguns atores) do OP e da AMPP como mecanismos democráticos, como também para determinar o declarado reconhecimento comum sobre a necessidade de melhorar na definição e execução democrática das políticas públicas.

As contribuições do OP e da AMPP para informar e propiciar debates nos quais se possa refutar ou aceitar as decisões antes de serem tomadas e executadas emergem como outra área onde foram declaradas algumas semelhanças, apesar do predomínio das diferenças. Nesse sentido, a principal similitude encontrada está no fato de a maioria dos atores não reconhecer a existência de capacidades para rejeitar decisões sobre questões "macro". A rejeição de decisões, no caso de Porto Alegre, acontece, sobretudo, no âmbito mais concreto, em comunidades e bairros, e apenas nos aspectos paliativos conforme já foi declarado. Em Cárdenas, a mencionada rejeição não é usual nem mesmo no âmbito local e mais concreto (bairros), segundo expressaram Delegados, habitantes e Pcp. 
Outra similitude identificada é a possibilidade do OP e da AMPP manterem a população informada sobre decisões relativas aos assuntos públicos. A experiência em Cárdenas, no entanto, mostrou que essas informações geralmente não são compartilhadas antes das decisões serem tomadas e executadas.

Por último, constatou-se igualmente que o OP e AMPP disponibilizam capacidades para que a população supervisione a execução de determinadas decisões no território, através de mecanismos diferentes e com implicações sociais também diferenciadas. Em Porto Alegre, a população reconheceu tais capacidades; em Cárdenas, esse reconhecimento se sustenta apenas no nível normativo. No entanto, mais um aspecto comum revelado foi o fato de que, na prática, existem algumas falhas na possibilidade de supervisão da execução das decisões nos dois territórios.

Considerando as informações sucintamente expostas até aqui, que constituem os principais resultados da pesquisa desenvolvida, as análises realizadas permitiram comparar o funcionamento do OP e da AMPP sobre a base das suas atuais contribuições para a democratização das decisões sobre os assuntos públicos, nos seus respectivos territórios. Simultaneamente, dessa análise comparativa emergem alguns elementos que podem contribuir para o aprimoramento das formas de compreender e analisar a democratização. Esses elementos são sintetizados a seguir e podem ser agrupados em aspectos empíricos, teóricos e epistemológicos.

Um primeiro elemento empírico complementa alguns aspectos mencionados anteriormente referentes às realidades do OP e da AMPP. Nesse sentido, se destaca que:

- Ambas as experiências servem fundamentalmente para legitimar o governo e as estruturas de poder, comprovando-se a ideia de HABERMAS (2003) sobre a esfera política pública como geração comunicativa de poder legítimo;

- Em ambas as experiências se enaltecem a vigência das instituições democráticas como equivalente da democratização, mais do que os cidadãos como referentes 
desse processo. Um exemplo disso são: 1) as limitações na incidência na elaboração estratégica da cidade; 2) retaliação de mecanismos alternativos (monopolização democrática), apesar do reconhecimento de alguns atores da necessidade de criar outros mecanismos; e 3) as restrições na produção de debates para refutar e aceitar determinadas decisões a serem executadas que afetem os interesses da população;

- Faz-se necessário aprofundar uma "alfabetização política" (COSTA, 1998) para minimizar a colonização autoritária das subjetividades (ACOSTA, 2014);

- Os comuns resultados entre ambas as experiências, em termos de limitações para executar sanções, incidir em certas políticas públicas, criar mecanismos alternativos, entre outros, estabelecem um diálogo com a ideia da não formalização das organizações da sociedade civil e da participação, presente tanto em alguns atores (Conselheiros e Delegados), quanto em certos autores (COSTA, $1995 \mathrm{com}$ base em HABERMAS, 1998). Nas duas experiências existe um desenho institucional orientado a promover os citados processos. Sem embargo, as formas diferentes em que nos marcos das suas semelhanças eles se executam dizem a respeito à necessidade de considerar duas ideias fundamentais: 1) outros aspectos condicionam os citados processos, a cultura política; 2) uma possível formalização do OP poderia não ter necessariamente os mesmos resultados em Cárdenas, por conta das características das subjetividades políticas, que poderiam imprimir formas diferentes de se formalizar essa experiência.

Um segundo elemento empírico destaca que, sobre a base das semelhanças achadas nas formas em que o OP e AMPP contribuem para democratizar as decisões públicas, ambas as experiências ainda precisam ser aprimoradas em relação a vários aspectos fundamentais em termos democráticos. Entre esses destacam:

- Diálogo e imbricação com outros possíveis mecanismos espontâneos de participação popular, que aprimorem os debates e tomada de decisões, sobre a base de uma maior heterogeneidade; 
- Transcendência de debates focados fundamentalmente em assuntos paliativos, para passar a discutir sobre a configuração da cidade como um "todo" articulado, de maneira que se facilite uma melhor distribuição de poder entre o governo e a sociedade civil nos processos decisórios;

- Maior divulgação das ferramentas nos seus territórios, para facilitar uma melhor representação social;

- Procurar mais eficiência na possibilidade de sanção da cidadania sobre os atores governamentais, de maneira que possam ser minimizados os descumprimentos relacionados com as demandas populares. Essas melhores formas de sanção poderiam contribuir para pressionar o governo a respeitar as diretrizes ao executar as obras;

- Aprimorar as capacidades de ambas as ferramentas no que diz respeito à incidência na definição de políticas públicas a partir de uma visão estratégica da cidade, e não apenas paliativa;

- Aprimorar as capacidades da população para rejeitar decisões sobre questões micro e macrossocial, que afetem os interesses dos cidadãos.

Por outro lado, como elementos teóricos e epistemológicos, pode-se ressaltar que:

- Reafirma-se a democratização como ferramenta analítica susceptível de ser reconsiderada em função das experiências empíricas (WHITEHEAD, 2011);

- Nos processos de democratização, assim como acontecem retrocessos e avanços, também podem acontecer estancamentos (como fase híbrida) sustentados na manutenção de requisitos mínimos de empoderamento da sociedade civil diante das decisões sobre os assuntos públicos. Essa fase, inclusive, poderia ser até mais funcional para o governo, considerando sua histórica natureza como entidade centralizadora de poder; 
- Para confirmar a ideia relativa ao estancamento como fase da democratização, se recomenda desenvolver outras pesquisas, onde se avaliem de um ponto de vista diacrônico as capacidades dos cidadãos e das cidadãs para democratizar as decisões sobre os assuntos públicos;

- O autoritarismo não é um passado do presente democrático (BEHREND, 2012; ACOSTA, 2014). Ele é um fundamento omnipresente das atuais supostas democracias, porquanto em ambas as experiências se percebem autoritarismos em relação à tomada de decisões relativas a determinadas áreas, como, por exemplo, a construção da cidade como um todo;

- Esses autoritarismos estão baseados em fases diferentes da configuração dos sistemas políticos: Estado - Mercado (HINKELAMMERT, 1990; ACOSTA, 2014);

- Para uma melhor análise e compreensão dos processos de democratização, recomenda-se considerar o papel historicamente cumprido pelo Estado na construção de cidadãos responsáveis e criticamente reflexivos. O Estado é responsável por facilitar estruturas que beneficiem a produção e reprodução de elementos cognitivos, afetivos e simbólicos, onde os próprios cidadãos reconheçam seus direitos e se autointerpretem como sujeitos ativos na construção da política;

- Para uma análise mais aprofundada sobre as reais capacidades da sociedade civil para democratizar as decisões sobre os assuntos públicos, se recomenda considerar a contextualização das decisões diante das quais a sociedade civil tem sido empoderada.

Um último aspecto a destacar, derivado dos resultados obtidos, é o papel que as diferenças achadas entre as experiências cumprem, a partir de uma perspectiva compreensiva. As posições diferenciadas adotadas pela população diante de processos como a sanção sobre os atores políticos, o estabelecimento de normativas para a definição da agenda de debates e para os processos decisórios, além da 
rejeição e/ou aceitação das decisões sobre os assuntos públicos antes de elas serem executadas, têm fatores similares como condicionantes que funcionam de maneira particular. Esses fatores podem ser agrupados em subjetivos e estruturais.

Como fatores subjetivos, se destaca que a interiorização feita pelos entrevistados em Cárdenas e em Porto Alegre sobre suas condições de sujeitos políticos em relação ao governo condicionam suas práticas diante dos processos citados. Em Porto Alegre, se percebem sujeitos mais ativos a partir do ponto de vista políticos, mais cientes das suas condições e dos seus direitos como sujeitos da configuração da política e, consequentemente, mais dispostos a exigir a construção coletiva das decisões. Essa percepção está associada a formas historicamente apreendidas de configuração de sentidos, conhecimentos e valores referentes aos processos políticos. O resultado disso são as atitudes desafiantes que comumente assumem perante atitudes ou decisões governamentais consideradas incorretas.

Em Cárdenas, onde também os sujeitos são configurados a partir de formas concretas de reprodução cultural, se percebem sujeitos mais passivos do ponto de vista prático, com inclinações a reproduzir uma ideia do governo como principal ator na configuração da política ${ }^{137}$ e com escasso hábito de exigir a construção coletiva das decisões. Desse modo, também se adverte que o poder popular não se assume como via para solucionar as problemáticas políticas-estruturais. Como consequência, se observa um conjunto de atores que, mesmo reconhecendo limitações em termos democráticos, não se dispõem a assumir atitudes desafiantes diante de decisões equívocas ou prejudiciais para a cidadania ${ }^{138}$

Desde a perspectiva estrutural, dos resultados exibidos emergem fundamentalmente vários fatores que contribuem para compreender as diferenças colocadas, não estando desvinculados dos elementos subjetivos anteriormente

${ }^{137}$ É necessário destacar que essa ideia está, maiormente, referida aos atores entrevistados no presente trabalho, que constituem supostamente os principais agentes responsáveis por impulsionar a democratização das decisões, como representantes do povo: Delegados de circunscrição, Presidentes dos Conselhos Populares. Em pesquisas anteriores, foram identificados outros atores com interpretações mais ativas.

138 Essa realidade coincide com pesquisas realidade na própria província de Matanzas (onde está localizada a cidade de Cárdenas) sobre os imaginários políticos (SUÁREZ, 2012). 
expostos. Esses fatores estão relacionados com o desenho político institucional e com o papel do Estado como agente facilitador de subjetividades democráticas, sem desconsiderar a transversalidade de outros fatores sociais: históricos, internacionais, conjunturais, econômicos, políticos, etc.

No que se refere a esse desenho institucional, o caráter centralizado da estrutura governamental cubana, mencionado nas primeiras seções da atual pesquisa, implica uma escassa distribuição de poder sobre as decisões. As formas organizacionais que sustentam os processos decisórios (instituições, atores, funções manifestas e latentes), caracterizadas por sua estrutura piramidal, tem viabilizado o papel do Estado central como responsável máximo pelas decisões. Isso tem esvaziado os níveis inferiores e a cidadania local de qualquer capacidade de tomada de decisões, tanto do ponto de vista prático quanto subjetivo. Essa forma de configuração institucional explica fatos como a pouca prática de sanções políticas sobre os atores governamentais por parte da população, o desconhecimento de experiências de rejeição de decisões e em geral a pouca disposição ${ }^{139}$ prática para transformar as estruturas de poder.

Em Porto Alegre, a realidade política se configura sobre a base de outras lógicas. A estrutura federalizada que implica maior grau de autonomia municipal, junto com a diversificação de atores locais favorecida entre outras questões pela própria extensão territorial, cria melhores condições institucionais para a produção e reprodução de capacidades para a tomada de decisões. Essas capacidades, que facilitaram o próprio surgimento do OP, têm contribuído para o estabelecimento de formas culturais mais apropriadas para o desenvolvimento de uma cidadania ativa e politizada. A partir dessas formas culturais, se compreendem sucessos como: as sanções políticas que a população porto-alegrense exerce sobre os atores governamentais, as experiências citadas de rejeição de decisões e, em geral, a

\footnotetext{
${ }^{139}$ Apesar da possibilidade de entender esse conceito a partir das ideias sobre o habitus de BOURDIEU (1997), nesse trabalho se opta por um sentido mais simples do mesmo, conforme o conceito de Hexis de Aristóteles, que foi reconfigurado posteriormente pelo próprio Bourdieu nas suas noções sobre o Habitus. Nesse sentido, Aristóteles (1959) assume por Hexis um estado da alma que não só é o resultado da prática, da habituação, da reiteração e do aprendizado, mas também determina a conduta e o comportamento do ser humano.
} 
disposição dos cidadãos para desafiar o governo na tentativa de transformar as estruturas de poder, pelos menos no âmbito municipal.

Até aqui, ficam demonstradas algumas semelhanças e diferenças entre o OP em Porto Alegre e a AMPP em Cárdenas, no que se refere às capacidades que facilitam a incidência dos cidadãos tanto na configuração das condições de tomada de decisões municipais quanto no controle do governo e dessas decisões.

Essas análises se materializaram na tentativa de contribuir com a acumulação de conhecimentos relativos aos processos democráticos num contexto mundial em que se reconhece que a democracia se encontra danificada (BOVERO, 2010). Esses danos, associados à arquitetura dos regimes que continuamos chamando de democráticos, assim como aos registros mentais dos cidadãos que vivem neles, exigem reflexões como as apresentadas, comprometidas com futuras ponderações reavaliativas que facilitem o aprimoramento justo dos seus conteúdos. 


\section{REFERÊNCIAS BIBLIOGRÁFICAS}

- ABERS, R. Inventing local democracy: grassroots politics in Brazil. Boulder: Lynne Rienner Publishers, 2000.

- ACKERMAN, John M. Democratización: pasado, presente y futuro. Perfiles Latinoamericanos, México, s./v., n. 28, p. 117-157, jul.-dic. 2006.

- ACOSTA, Y. Novas democracias e outras democracias na América Latina. Revista de Estudos e pesquisa sobre as Américas. V.8, No. 2, ISSN 19841639, Pp. 30-58, Brasília, 2014.

- ACOSTA, Y., GIORDANO, V. y SOLER, L. América Latina: nuestra. In: Trotta, N y Gentili, P. (Comp.). “América Latina. La democracia en la encrucijada”. La Página S.A, Buenos Aires, 2016.

- ANPP. Apuntes sobre las responsabilidades y la labor de los delegados a las Asambleas Municipales. Comisión de Órganos Locales. La Habana, 1999.

- ANPP. Constitución de la República de Cuba. Editora Política. La Habana. Cuba, 2010.

- ANPP. Ley 91 de los Consejos Populares. Gaceta Oficial de la República, edición extraordinaria No. 6. La Habana. Cuba, 2000.

- ANPP. Reglamento de las Asambleas Municipales del Poder Popular. Editora Política. La Habana. Cuba, 1995. 
- ANSALDI, M. La democracia en América Latina: un barco a la deriva. Buenos Aires: FCE, 2007.

- ARISTÓTELES. Ética a Nicómaco. Centro de Estudios Políticos y Constitucionales. Madrid, España, 1959.

- AUGUST, Arnold. Cuba y sus vecinos: Democracia en movimiento. $1^{\text {ra }}$ Edición en Español. Editorial Ciencias Sociales, La Habana, 2015.

- AVRITZER, L. El Presupuesto participativo y la teoría democrática: un balance crítico. Em: Leonardo Avritzer. "Los desafíos de la participación en América Latina". $1^{\text {ra }}$ edición. Buenos Aires, Prometeo Libros, 2014.

- AVRITZER, L. Modelos de deliberação democrática: uma análise do Orçamento Participativo no Brasil. Em: Boaventura de Sousa Santos. "Democratizar a democracia. Os caminhos da democracia deliberativa". Rio de Janeiro, Civilização Brasileira, 2002a.

- AVRITZER, L. Sociedade civil, espaço público e poder local: uma análise do Orçamento Participativo em Belo Horizonte e Porto Alegre. In: Dagnino, E. “Sociedade civil e espaços públicos no Brasil”. São Paulo, Paz e Terra, 2002b.

- BAIERLE, Sergio G.. Crise do sujeito, otimismo cruel e exclusão participativa. Cidade, Centro de Assessoria e Estudos Urbanos Texto apresentado no Encontro Ettern/UFRJ Vassouras, Rio de Janeiro, Abril, 2012.

- BAIERLE, Sergio G. Porto Alegre neoliberal: a decapitação social-capitalista de líderes comunitários e os limites do Novo Gerencialismo Público inclusivo. Coleção Cadernos da CIDADE, Centro de Assessoria e Estudos Urbanos № . 15, volume 12, Porto Alegre, 2009.

- BAIERLE, Sergio G. A explosão da experiência. Emergência de um novo princípio ético-político nos movimentos populares urbanos em Porto Alegre. 
Em: Sonia E. Alvarez, Evelina Dagnino, Arturo Escobar (organizadores). Belo Horizonte, Ed. UFMG, 2000.

- BAIOCCHI, G. Militants and citizens: the politics of participation in Porto Alegre. Stanford University Press, 2005.

- BAZZI, A.P. Democracia versus Neoliberalismo. 25 años de neoliberalismo en Chile. CLACSO, Buenos Aires, 2015.

- BEHREND, Jacqueline. Democratización subnacional: algunas preguntas teóricas. POSTData 17, No2, ISSN 1515-209X, Pp. 11-34, Octubre, 2012.

- BENDIX, R. Concepts and Generalizations in Comparative Sociological Studies. American Sociological Review, v.28, \#4, 1963.

- BERNS, Walter. On Robert Dahl's Important Questions. American Political Science Review No 52, 1958 pp. 830-833.

- BOBBIO, Norberto. El futuro de la democracia. Traducción de José F. Fernández Santillán. FCE, México, D. F., 1986.

- BOURDIEU, P. Distinción. Criterios y bases sociales del gusto. TAURUS, D/F México, 2002.

- BOURDIEU, Pierre. El oficio del sociólogo. Presupuestos epistemológicos. Editores Siglo XXI, S.A. Buenos Aires, 1975.

- BOURDIEU, Pierre. Razones prácticas: Sobre la teoría de la acción. Edit. Anagrama. Barcelona, 1997.

- BOVERO, M. La democracia y sus condiciones. Tradução do italiano de Lorenzo Córdova Vianello e Paula Sofía Vázquez Sánchez. Revista de la Facultad de Derecho de México, Ciudad de México, tomo LX, n. 253, p. 11-29, jan.-jun., 2010. 
- BRIGOS, Jesús P. García. Gobernabilidad y democracia: Los Órganos del Poder Popular en Cuba. Editorial de Ciencias Sociales, La Habana, 1998.

- CABANNES, Yves. Presupuesto Participativo y finanzas locales. Programa de Gestión Urbana PGU -ALC / UN - HABITAT, Alcaldía Municipal de Porto Alegre, Brasil Quito.- Programa de Gestión Urbana - UN/HABITAT. Mayo 2004.

- CÂMARA DOS DEPUTADOS. Constituição da Repúbica Federativa do Brasil. $35^{a}$ edição. Centro de Documentação e Informação edições Câmara, Brasília, 2012.

- CAMPORREDOndo, Ada Guzón. (Compiladora). Desarrollo Local en Cuba. Retos y Perspectivas. In: Ada Guzón Camporredondo: Estrategias municipales para el desarrollo. Editorial Academia. La Habana, 2006.

- CASANOVA, P.G. América Latina y el mundo: crisis, tendencias y alternativas. In: Trotta, N y Gentili, P. (Comp.). "América Latina. La democracia en la encrucijada". La Página S.A, Buenos Aires, 2016.

- CAVAROZZI, M. El capitalismo político tardío y su crisis en América Latina. Rosario: Homo Sapiens, 1996.

- CHAGUACEDA, Armando (comp). Participación ciudadana y espacio asociativo: desafíos en el contexto cubano. In: Armando Chaguaceda. "Participación y espacio asociativo". Ediciones Acuario, La Habana, 2008.

- CHAGUACEDA, Armando e GEOFFRAY, Marie Laure. Las reformas en cuba: que sigue, que cambia, que falta. Association for the Study of the Cuban Economy (ASCE). Cuba in Transition: Vol. 23, 2013.

- CHAGUACEDA, Armando. Políticas de participación y prácticas de autonomía en la Cuba actual. In: Armando Chaguaceda y Cassio Brancaleone (Org). Sociabilidades emergentes y movilizaciones sociales en América Latina. 1a ed. Ciudad Autónoma de Buenos Aires : CLACSO, 2012. 
- CHERESKY, I. ¿Qué democracia en América Latina? CLACSO, Buenos Aires, 2012.

- COHEN, J. y ARATO, A. Sociedad civil y teoría política. Fondo de Cultura Económica, México, 2002.

- CONNOLLY, William E. Political Science and Ideology. Atherton: New York, 1967.

- COSTA, Sergio. A democracia e a dinâmica da esfera pública. Lua Nova No. 36, 1995.

- DAGNinO, E.; et al. La disputa por la construcción democrática en América Latina. México: FCE, 2006

- DAHL, Robert. On Democracy. Yale University Press: New Haven, 1998. Versão em português: "Sobre a democracia”. Editora UnB, Brasília, 2001.

- DAHL, Robert. Poliarquia: participação e oposição. EDUSP, São Paulo, Brasil, 2005 .

- DILLA Alfonso, Haroldo. Cuba: ¿transición o continuidad? Revista Herramienta No 35, Bueno Aires, Junio 2007.

- DILLA Alfonso, Haroldo. Cuba: ¿transición o democracia? Revista Herramienta N ${ }^{\circ}$ 35. Ciudad Autónoma de Buenos Aires, Junio, 2007.

- DILlA Alfonso, Haroldo. Cuba: los entornos cambiantes de la participación. América Latina, Hoy No. 24, Pp. 19-26, Abril, 2000.

- DILLA Alfonso, Haroldo. Montos comunitarios y municipios en Cuba: conflictos y cooperación. Informe preliminar. CEA, La Habana, 1996. 
- DUNCAN, G. \& LUKES, S. The New Democracy. Political Studies11, 1963 pp.156177.

- EDELMAN, Murray. Research orientations: Some Pitfalls and Some Strategic Suggestions. In: Kariel, H.S (ed.). Frontiers of Democratic Theory. Random: New York, 1970.

- ELSTER, J. (Comp.) La democracia deliberativa. Gedisa, Barcelona, España, 2001

- ESPINA, Maira Paula: Apuntes sobre el concepto de desarrollo y su dimensión territorial. In: Ada Guzón Camporredondo: Estrategias municipales para el desarrollo. Editorial Academia. La Habana, 2006.

- FEDOZZI, Luciano; Adriana Furtado; Valéria Dozolina Sartori Bassani; Carlos Eduardo Gomes Macedo; Cidriana Teresa Parenza; Milton Cruz. Orçamento participativo de Porto Alegre. Perfil, avaliação e percepções do público participante. Porto Alegre: Gráfica e Editora Hartmann, 2013.

- FILMUS, D. Una década de transformaciones en América Latina. In: Trotta, N y Gentili, P. (Comp.). “América Latina. La democracia en la encrucijada”. La Página S.A, Buenos Aires, 2016.

- FLEITES, Cecilia L. et., al. Participación. Diálogo y debate en el contexto actual. Centro de Investigación y Desarrollo de la Cultura Cubana "Juan Marinello”. La Habana. 2004.

- GADAMER, Hans-Georg. Verdade e método. Traços fundamentais de uma hermenêutica filosófica. $3^{\text {ra }}$ Edição, Editora VOZES, Petrópolis, 1999.

- GALEANO, E. Las venas abiertas de América Latina. Siglo XXI, Buenos Aires, 2010. 
- GEARY, M. et al. (Comp.) Política latinoamericana comparada. Rosário: UNR, 2015 .

- GERMANI, Gino. Democracia y autoritarismo en la sociedad moderna. Em: Germani, G. et al. Los límites de la democracia. Vol. 1. CLACSO, Buenos Aires, 1985

- GÓMEZ, G.R. et. al. Metodología de la Investigación Cualitativa. Santiago de Cuba: PROGRAF, 2002.

- GONZALES, Aimée y SAMPER, Yunaimys. Iniciativa municipal para el desarrollo local: una propuesta novedosa. In: Ada Guzón Camporredondo: Estrategias municipales para el desarrollo. Editorial Academia. La Habana, 2006.

- GONZÁlEZ, Rodrigo Stumpf. Novos espaços da Democracia no Brasil: a participação popular na definição do orçamento público. Em: Rodrigo Stumpf González. (Comp.) "Perspectivas sobre participação e democracia no Brasil". Editora UNIJUÍ, Ijuí, 2007.

- GRAMMONT, H.C.de (Comp.) La construcción de la democracia en el campo latinoamericano. CLACSO, 2006.

- GUACH, Hans C. e NEGRI, Camilo. LAS SESIONES DE LA AMPP EN CUBA: implicaciones subjetivas y prácticas desde un estudio de caso. Em: Igreja, R. L. e de Novion, J. (Org.) POLÍTICA EM MOVIMENTO: a construção da política na América Latina e Caribe. Coleção Américas Compartilhadas. Curitiva: CRV, 2016.

- GUACH, Hans. Órganos municipales del Poder Popular en Cuba. Un estudio de caso. In: Ángela Isabel Peña Farías (Org.) "Desigualdad, pobreza y gobiernos locales: problemas del desarrollo cubano", $1^{\text {ra }}$ Edicón, Editorial UH, La Habana, 2016. 
- GUANCHE, J.C, Participación ciudadana en el Estado cubano. Revista TEMAS, no. 70, Abril-Junio 2012, pp. 69-79, La Habana, Cuba, 2012.

- GUANCHE, Julio César. El lugar de la ciudadanía. Participación política y República en Cuba. Conferencia impartida el 2 de julio de 2011, en el Centro Cultural Padre Félix Varela, auspiciado por Revista Espacio Laical. Espacio Laical $3 / 2011$.

- GUANCHE, Julio César. La participación ciudadana en el Estado cubano. Revista TEMAS, No. 70: 69-79, La Habana, abril-junio, 2012.

- HABERMAS, J. Facticidad y validez. Sobre el derecho y el Estado democrático del derecho en términos de teoría del discurso. Traducción de Manuel Jiménez Redondo. Editora Trotta, Madrid, España, 1998.

- HABERMAS, J. Tres modelos de democracia. Sobre el concepto de una política deliberativa. Revista Polis, Vol. 4 num. 10, p. 0, Universidad Bolivariana, Chile, 2005.

- HABERMAS, Jürgen. Mudança estrutural da esfera pública: investigações quanto a uma categoria da sociedade burguesa. Tradução: Flávio R. Kothe. Rio de Janeiro: Tempo Brasileiro, 2003. 398p.

- HELD, D. Modelos de democracia. Belo Horizonte: Paidéia, 1987.

- HINKELAMMERT, Franz. Democracia y totalitarismo. San José, Costa Rica, DEI, $2^{\mathrm{a}}$ ed., 1990.

- HOPENHAYN, Martín. Viejas y nuevas formas de la ciudadanía. Revista de la CEPAL no. 73, Abril, 2001.

- HUNTINGTON, S.P. La tercera ola. La democratización a finales del siglo XX. Editorial Paidós, 1994. 
- IAZZETTA, Osvaldo. Democracia y Estado en tres décadas (1983-2013): entre la estatalidad lograda y la necesaria. ESTUDIOS - $\mathrm{N}^{\circ} 30$-ISSN 0328-185X (JulioDiciembre) Pp. 257-280, Universidad Nacional de Córdoba, 2013.

- IAZZETTA, Osvaldo. Democracia, calidad de la democracia y democratización. REVISTA DEBATES, v. 7, n. 1, p.139-150, jan.-abr. Porto Alegre, 2013.

- KELSEN, Hans. El Estado como integración. Una controversia de principio. Tecnos, Madrid, 1997.

- KING, Desmond, LIEBERMAN Robert C., RITTER Gretchen and WHITEHEAD Laurence (eds.). Democratization in America. A comparative-Historical Analysis. Baltimore, Johns Hopkins University Press, 2009.

- LATINOBARÓMETRO. Opinión pública latinoamericana. Chile: Corporación Latinobarómetro, 2015.

- LECHNER, N. De la revolución a la democracia. El debate intelectual en América del Sur. La Ciudad Futura. Revista de Cultura Socialista, 2, Pp. 33-35, (Octubre), 1986.

- LEE, Donald J. Poliarchy. The Political Theory of Robert Dahl. Gatland: New York, 1991.

- LEVINE, D.H. y MOLINA, J.E. Notas sobre la calidad de la democracia en América Latina: Índice específico y evaluación comparada de los países. Latin American Studies Association, Montréal, 2007.

- LINZ, Juan \& STEPAN, Alfred. Problems of Democratic Transition and Consolidation. Baltimore, Johns Hopkins University Press, 1996.

- LISSIDINI, A. Democracia directa en Latinoamérica: Entre la delegación y la participación. CLACSO, 2011. 
- LISSIDINI, A. et al. Democracias en movimiento. Mecanismos de democracia directa y participativa en América Latina. México: UNAM, 2014.

- LUCCA, J. B. y PINILlOS, C. La agenda de la política comparada en América Latina.E-1@tina, Vol. 14, núm. 53, Buenos Aires, 2015.

- LUCHMANN, Ligia Helena Hahn. Possibilidades e limites da democracia deliberativa: a experiência do orçamento participativo de Porto Alegre. (Tese de Doutorado apresentada ao Departamento de Ciência Política). Universidade Estadual de Campinas. Instituto de Filosofia e Ciências Humanas, Programa de PósGraduação em Ciências Sociais, 2002.

- MACPHERSON, C.B. La democracia liberal y su época. Traducción de Fernando Santos Fontela. Editorial Alianza, Madrid, 2003.

- MAINWARING, S \& SHUGART, M. Presidentialism and Democracy in Latin America. Cambridge Univ. Press, 1997.

- MARQUETTI, Adalmir. Participação e redistribuição: o Orçamento Participativo em Porto Alegre. Em: AVRITZER, Leonardo e NAVARRO, Zander: “A inovação democrática: O Orçamento participativo no Brasil”. $1^{\text {ra. }}$ edição, São Paulo: Cortez, 2002.

- MILLS, Ch.W. The Power elite. New York, Oxford University Press, 1956.

- MILLS, Ch.W. The Structure of Power in American Society. The British Journal of Sociology, Vol. 9, No. 1, Pp. 29-42, Mar., 1958.

- MOKRANI, Dunia Chávez. Reflexiones sobre la democracia y el significado de un gobierno de los movimientos sociales en Bolivia. In: Margarita Favela Gavia y Diana Guillen (Coord.). “América Latina. Los derechos y las prácticas ciudadanas a la luz de los movimientos populares”. CLACSO , Buenos Aires, 2009. 
- MORLINO, L. Democracia y Democratización. Madrid: CIS, 2009

- MORLINO, L. Problemas y opciones en la comparación. In: SARTORI, G. e MORLINO, L. “La comparación en las ciencias sociales”. Madrid: Alianza, 1994.

- MUNCK, G. Agendas y estrategias de investigación en el estudio de la política latinoamericana. Revista de Ciencia Política, Vol. 27, № 1, Chile, 2007.

- NOHLEN, Dieter. Desafíos de la democracia contemporánea. Revista Elecciones, no. 2, Pp. 11- 22. Oficina Nacional de Procesos Electorales, Lima, 2003.

- O`DONNELL, G e SCHMITTER, Ph. Transiciones desde un gobierno autoritario. Conclusiones tentativas sobre las democracias inciertas. Buenos Aires: Paidós, 1991.

- O`DONNELL, G. Estado, democratización y ciudadanía. Revista Nueva Sociedad, No 128 , Caracas, 1993.

- O'DONNELL, G. Acerca del estado en América Latina contemporánea: diez tesis para discusión. Em: Programa de Naciones Unidas para el Desarrollo (PNUD). "La democracia en América Latina. Hacia una democracia de ciudadanas y ciudadanos". PNUD, Buenos Aires, 2004.

- O'DOnNELl, G. Democracia, agencia y estado. Teoría con intención comparativa. Buenos Aires: Prometeo, 2010.

- O'DONnEll, G. Hacia un Estado de y para la democracia. En Democracia/Estado/Ciudadanía. Hacia un Estado de y para la Democracia en América Latina. PNUD, Lima, 2008.

- ONEI (Oficina Nacional de Estadística e Información). Anuario Estadístico de Cárdenas 2014. Edición 2015. 
- OSIPOV, G et. al. Libro de Trabajo del Sociólogo. La Habana: Ciencias Sociales, 1988.

- PALMIRA, Edith G. (2000). (Tesis en opción al título de Doctor en Ciencias Filosóficas). La democracia como valor político de la sociedad cubana actual. Universidad de La Habana, 2000.

- PATEMAN, Carole. Participation and Democratic Theory. Cambridge University, Press, 1970.

- PAZ, Juan Valdés. El espacio y el límite. Estudios sobre el sistema político cubano. Instituto Cubano de Investigación Cultural Juan Marinello, Ruth Casa Editorial, La Habana, 2009.

- PAZ, Juan Valdés. La transición socialista en Cuba: continuidad y cambios. Editorial Colihue, Buenos Aires, 1993.

- PLEYÁN, Carlos García. Desarrollo Local y gestión del conocimiento. In: Ada Guzón Camporredondo: Estrategias municipales para el desarrollo. Editorial Academia. La Habana, 2006.

- PMPA (PREFEITURA MUNICIPAL DE PORTO ALEGRE). Regimento interno. Critérios gerais, técnico e regionais - 2015/2016. Impressão Gráfica Erechim, Porto Alegre, 2015.

- PNUD. Informe sobre Desarrollo Humano. Fondo de Cultura Económica S.A., Primera edición en español. México D/F, 1994.

- PNUD. Informe sobre Desarrollo Humano. Fondo de Cultura Económica S. A. Primera edición en español. México D/F, 1994. 
- PREFEITURA DE PORTO ALEGRE. Governança Solidária Local. Documento de Referência. Porto Alegre: Secretaria de Coordenação Política e Governança Local, 2005.

- PRZEWORSKI, A. and TEUNE, H. The logic of comparative social inquiry. New York: John Wiley ans Sons. Pp 31-46, 1970.

- PRZEWORSKI, Adam. Qué esperar de la democracia. Límites y posibilidades del autogobierno. Siglo XXI, Buenos Aires, 2010.

- PUIG, S.M. Los múltiples debates (y realidades) de la democracia en América Latina. CIDOB d'Afers Internacionals, núm. 85-86, Barcelona, 2009.

- RAGIN, Ch.C. La construcción de la investigación social. La introducción a los métodos y su diversidad. Bogotá: Siglo del Hombre, 2007.

- RAGIN, Charles C. The comparative method: moving beyond qualitative and quantitative strategies. University of Calífornia Press, Berkeley and Los Ángeles, California, 1987.

- RINGER, Fritz. A metodologia de Max Weber: unificação das Ciências culturais e sociais. Trad. Gilson César Cardoso de Souza. Editora Universidade de São Paulo, EDUSO, 2004.

- RÍOS, Olga F. Cuba: participación popular y sociedad. Ediciones CEA. La Habana, 1996.

- ROSENMANN, M.R. Las razones de la democracia em América Latina. Madrid: Sequitur, 2001.

- RUBIN, Jeffrey W. and BAIERLE, Sergio Gregorio. Democracy by Invitation: The Private Sector's Answer to Participatory Budgeting in Porto Alegre, Brazil. In: 
Jeffrey W. Rubin and Vivienne Bennett. "Progressive Activism and Private Sector Responses in Latin America's Democracies”. University of Pittsburgh Press, 2014.

- RUZ, Fidel Castro. La historia me absolverá. Ed. Ciencias Sociales. La Habana, 2007.

- SANTOS, Boaventura de Sousa e AVRITZER, Leonardo. Para ampliar o cânone democrático. Em: Boaventura de Sousa Santos. "Democratizar a democracia. Os caminhos da democracia deliberativa". Rio de Janeiro, Civilização Brasileira, 2002.

- SANTOS, Boaventura de Sousa. Participatory budgeting in Porto Alegre: towards a redistributive democracy. Politics and Society, 26, no. 4, Pp. 461-510, 1998.

- SARTORI, G. ¿Qué es la Democracia? Taurus, Madrid, 2003.

- SARTORI, G. A teoria da democracia revisitada. Vol. I: O debate contemporâneo. Editora Ática, S.A., São Paulo, 1994.

- SARTORI, G. Compare Why and How: Comparing, Miscomparing and the Comparative Method. In: DOGAN, Mattei, KAZANCIGIL, Ali. Comparing nations: concepts, strategies, substance. Blackwell, Oxford \& Cambridge, Pp. 1435, 1994.

- SCHUMPETER, Joseph A. Capitalismo, Socialismo e Democracia. Editado por George Allen e Unwin Ltd., traduzido por Ruy Jungmann. Fundo de Cultura, Rio de Janeiro, 1961.

- SUÁREZ, Raudelio Machín. El imaginario político y su función en el perfeccionamiento del proyecto democrático cubano. - 1a ed. - Buenos Aires: Consejo Latinoamericano de Ciencias Sociales - CLACSO, 2011.

- TILLY, CH. Democracia. Madrid: AKAL, 2010. 
- VARGAS-CULLELL, J. La calidad de la democracia y el estudio comparado de la democratización. Revista latinoamericana de Política Comparada, CELAEP, Vol. No.5, pp.67-94, Julio 2011, Quito, 2011.

- VERGARA, J. La concepción de la democracia deliberativa de Habermas. Revista Quorum Académico, dic., vol. 2, no.2, p.72-88, 2005.

- WEBER, M. Economía y Sociedad. La Habana: Ciencias Sociales, 1979.

- WHITEHEAD, L. Democratization. Theory and Experience. Oxford University Press, 2002. Tradução ao español: Democratización. Teoría y experiencia. Fondo de Cultura Económica, México, 2011.

- WHITEHEAD, L. Un concepto de democratización reanimado: la metáfora biológica. Revista SAAP (ISSN 1666-7883) Vol. 5, Nº 2, noviembre 2011, 401-419.

- WHITEHEAD, Laurence. The 'puzzle' of autocratic resilience/regime collapse: the case of Cuba. Journal Third World Quarterly, Volume 37, Issue 9, 2016.

- WILliAMS, Raymond. Marxismo y literatura. Editorial Península. Barcelona, 1980.

- XAVIER, L.d.O. e AVILA C.F.D (Orgs.) A qualidade da democracia no Brasil: questões teóricas e metodológicas da pesquisa. Vol.1. Curitiva: CRV, 2016.

\section{SITES UTILIZADOS.}

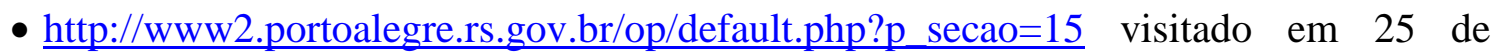
outubro de 2016.

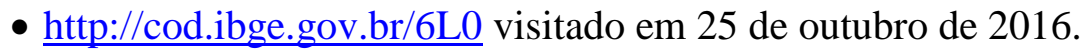


- Nome:

- Cargo y/o ocupação:

- Nível de escolaridade:

- Data da entrevista:

- Horário:

- Local da entrevista:

\section{Sobre capacidades de influir nas condições da tomada de decisões.}

a) Como contribui o OP para facilitar a execução de procedimentos (alternativos ou não) que fortaleçam o debate público e a tomada de decisões sobre os assuntos públicos?

b) Como o OP favorece a discussão (refutação e ou aceitação) de normativas para regularizar a tomada de decisões sobre os assuntos públicos em Porto Alegre?

c) Como o OP facilita que a população supervise a definição da agenda dos debates públicos em Porto Alegre e, além, influencie nos modos de definir essa agenda?

\section{Sobre capacidades de controle dos atores políticos.}

a) Como o OP facilita que a população obtenha informações sobre a gestão dos atores políticos (relacionadas com as demandas púbicas) e as suas justificativas?

b) Como o OP oferece capacidades para que a população avalie a gestão dos atores políticos, frente às demandas públicas?

c) Quais capacidades de sansão sobre os atores políticos tem o OP em Porto Alegre? 
III. Sobre capacidades de controle das decisões.

a) Quais capacidades oferece o OP para que a população incida na definição das políticas públicas?

b) Como contribui o OP para informar à população sobre as decisões relativas aos assuntos públicos, antes de elas serem executadas?

c) Como o OP contribui para discutir (aceitar e/ou refutar) as decisões sobre os assuntos públicos, antes de elas serem executadas?

d) O OP contribui para supervisar a execução das decisões tomadas no território? Argumente sua resposta. 
- Nome:

- Filiação institucional:

- Cargo e/ou ocupação:

- Experiência no cargo ou ocupação:

- Formação acadêmica:

- Data da entrevista:

- Horário:

- Local da entrevista:

\section{Sobre capacidades de influir nas condições da tomada de decisões.}

a) Qual é sua valoração sobre as capacidades do OP / da AMPP para propiciar debates em relação com o possível estabelecimento de procedimentos (alternativos ou não), que fortaleçam o debate público e a tomada de decisões sobre os assuntos públicos no território?

b) Como você avalia as capacidades OP / da AMPP para incidir na configuração normativa dos processos de tomada de decisões sobre os assuntos públicos, sejam no âmbito comunitário e/ou municipal?

c) Qual é sua opinião sobre a maneira em que se define a agenda de debates públicos e o papel cumprido pelo OP / e pela AMPP na definição dessa agenda?

\section{Sobre capacidades de controle dos atores políticos.}

d) Como valoriza o papel do OP / da AMPP no fornecimento de informações à população, sobre a gestão governamental em função das demandas públicas e suas justificativas? 
e) Como valoriza as capacidades que tem tido o OP / a AMPP para facilitar a avaliação da gestão dos atores políticos diante as demandas públicas, por parte da população?

f) Qual é sua valoração sobre as capacidades que hoje tem o OP / a AMPP, para sancionar aos atores governamentais diante de descumprimentos e/ou ações inapropriadas realtivas aos assuntos públicos?

\section{Sobre capacidades de controle das decisões.}

e) Como avalia as capacidades que oferece o OP / a AMPP para que a população incida na definição das políticas públicas no território?

f)Qual é o papel que cumprem hoje o OP / a AMPP nos processos de informação referentes às decisões sobre os assuntos públicos, antes que elas sejam executadas?

g) Como valoriza as capacidades para gerar espaços onde se discutam, aceitem e/ou refutam decisões governamentais sobre os assuntos públicos, antes de elas serem executadas?

h) Qual é sua avaliação sobre as capacidades que oferecem o OP / a AMPP para que a população supervise e avalie a execução das decisões tomadas no território? 